\title{
A PRELIMINARY REVISION OF THE FAMILIES AND SUBFAMILIES OF ACRIDOIDEA (ORTHOPTERA, INSECTA)
}

\author{
By V. M. DIRSH \\ Anti-Locust Research Centre, London
}

CONTENTS

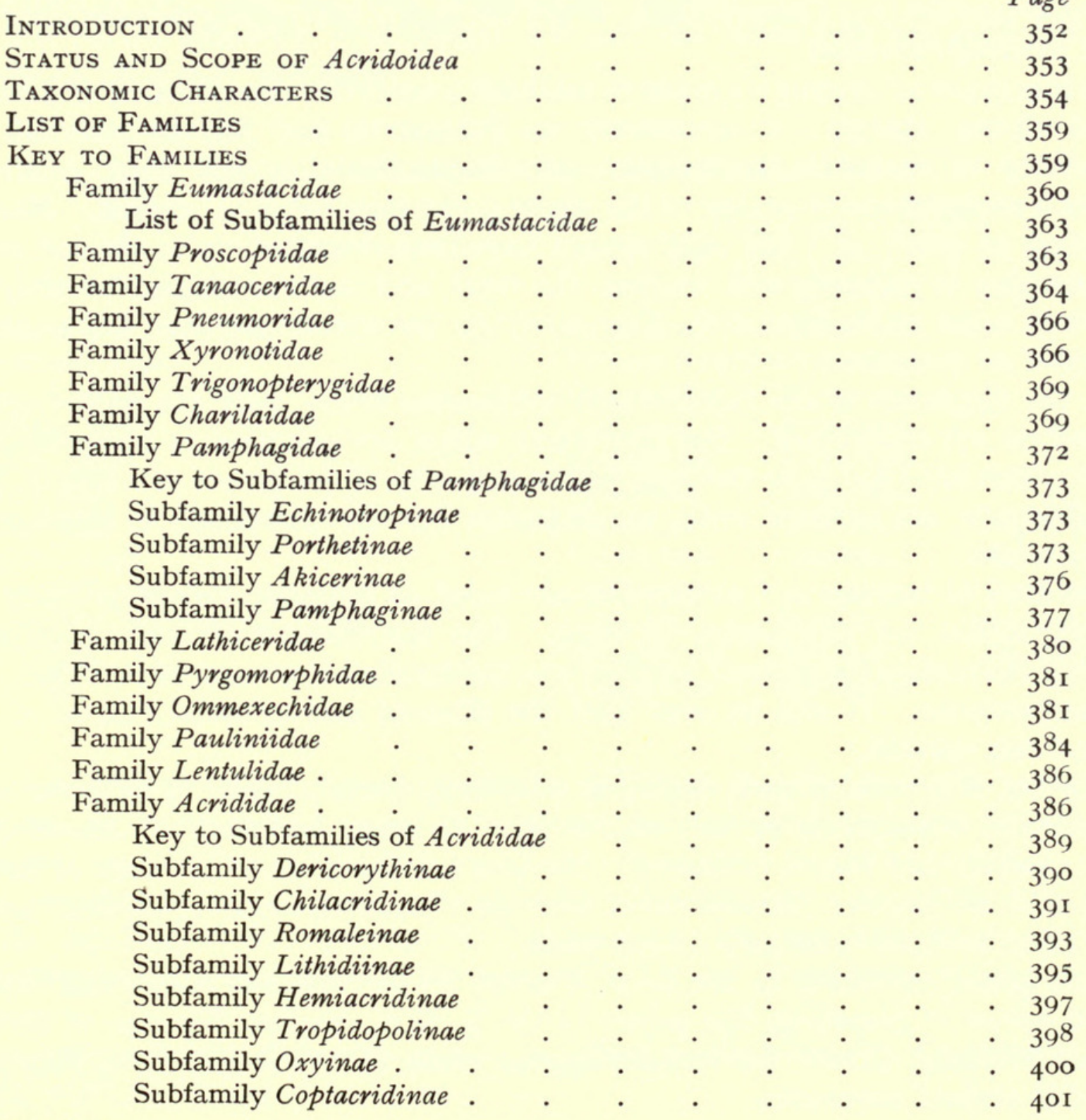

ENTOM. IO, 9. 


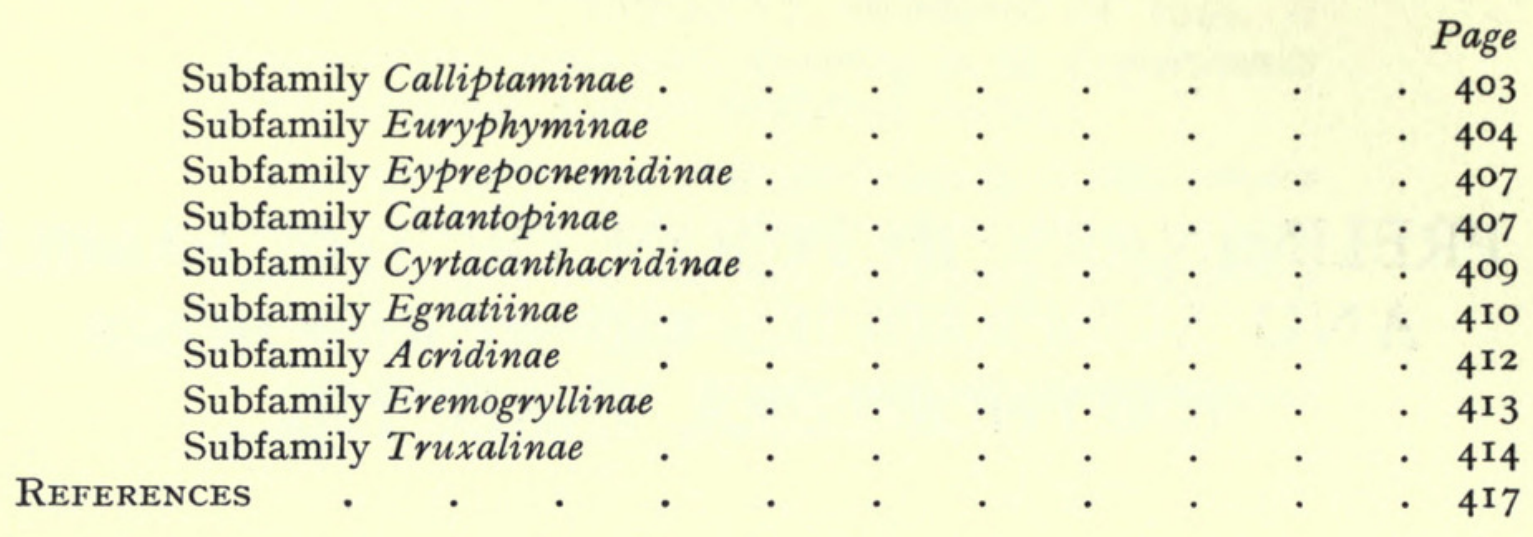

\section{INTRODUCTION}

THE status and scope of families and subfamilies of Acridoidea have undergone many changes, but the general system within the group is still far from adequate. A few families are well defined, but there are others (e.g. Eumastacidae), and also some subfamilies (e.g. Catantopinae), which are highly heterogeneous assemblages and need thorough revision.

In this paper an attempt is made to establish a tentative classification of Acridoidea based mainly, though not exclusively, on Palaearctic and African material. Insufficiency of material, particularly from South America and from Australasia, makes a comprehensive review of the whole group impossible at present. Moreover, although as many as 1,527 valid genera have been described up to the end of $195^{8}$, this number is probably still far from the total, and one may expect possibly twice as many more to be described. Consequently, the system outlined below must be regarded as preliminary only.

In the diagnoses of the families and subfamilies below, only the most important characters are mentioned. The characters which are common to all families, and those which have not been checked for the majority of the genera of a certain family or subfamily, are omitted from the diagnoses but are mentioned in discussions or in the tables.

The keys to families and subfamilies are based on external characters only, which usually suffice for recognition of them. The distribution of both external and internal characters throughout families and subfamilies is presented in Tables II and III respectively. It will be seen that the internal and external characters often do not run parallel.

The list of genera of each family or subfamily includes only those examined by the author, arranged in alphabetical order. In many cases all the known genera were studied, and this is indicated. No lists are provided in the case of the very large and sufficiently distinct units such as Pyrgomorphidae, Acridinae and the somewhat artificial subfamily Catantopinae.

I am greatly indebted to Dr. B. P. Uvarov for his valuable advice and criticism in the course of preparing this paper, to Dr. T. H. C. Taylor, Director of the AntiLocust Research Centre, for sponsoring this work, and to Dr. K. H. L. Key for his valuable critical comments. 


\section{STATUS AND SCOPE OF ACRIDOIDEA}

The systematic position of Acridoidea, as suggested in recent leading orthopterological and general entomological works, is presented in Table I. The main changes in this century have been as follows :

Handlirsch (I908) divided the order Orthoptera Latreille, I793 (= Saltatoria Latreille, I8I7), into the suborder Locustoidea, with the families Locustidae (= Tettigoniidae), Gryllidae, Tridactylidae, and Gryllotalpidae, and the suborder Acridioidea with a single family Acridiidae.

Ander (I939) divided the order Saltatoria into the suborders Ensifera and Caelifera, the first of which corresponds to Handlirsch's Locustoidea and the second to Handlirsch's Acridioidea, except that he transferred the family Tridactylidae to the suborder Caelifera as a superfamily. Acridoidea were regarded by him as the second superfamily of the suborder.

Some authors, however, even earlier (Jakobson \& Bianki, I904), regarded all the superfamilies of Ander as suborders. Others (Schvanwitsh, I949) omitted the term suborder and used the term superfamily instead.

In this paper, following Handlirsch's scheme, the Acridoidea are regarded as a suborder of the order Orthoptera.

\section{TABLE I.-Changes in the Status of Acridoidea}

\section{Authors}

Jakobson \& Bianki, 1904

Handlirsch, I908

Chopard, 1920

Schröder, I925

Uvarov, I928

Weber, 1938 .

Ander, 1939 .

Chopard, 1949

Shvanwitsh, 1949

Bey-Bienko \& Mistshenko, I95I

Beier, I955 .

This work
Taxonomic categories

\begin{tabular}{llc}
\multicolumn{1}{c}{ Order } & \multicolumn{1}{c}{ Suborder } & Superfamily \\
Orthoptera & Acridiodea & - \\
Orthoptera & Acridioidea & - \\
Orthoptera & Locustodea & - \\
Saltatoria & Acridiodea & - \\
Orthoptera & Acridodea & - \\
Saltatoria & Acridoidea & - \\
Saltatoria & Caelifera & Acridoidea \\
Orthoptera & Caelifera & Acridoidea \\
Orthoptera & - & Acridoidea \\
Orthoptera & Caelifera & Acridoidea \\
Saltatoptera & Caelifera & Acridides \\
Orthoptera & Acridoidea & -
\end{tabular}

A question concerning the scope of the suborder Acridoidea is the position of Tetrigidae, which some authors continue to regard as one of the families of Acridoidea, although Chopard (I920), Walker (I9I9-22), Snodgrass (I937), Carpentier (I932, I936), and Ander (I939) have proved that this view is incorrect. Beier (I955) has formally established the superfamily Tetrigides as equal in rank to his Acridides (= Acridoidea $)$ and consisting of the families Tetrigidae, Tridactylidae and Cylindrachetidae.

Beier's superfamily Tetrigides is here regarded as the suborder Tetrigoidea, equal in rank with Acridoidea. 
A discussion of affinities of Tetrigoidea with other Orthopteroid groups is outside the scope of this paper, but the main characters separating them from Acridoidea are as follows ${ }^{1}$ :

I. The thoracic skeletons of Tetrigidae and Acridoidea in many essential features are very different (Carpentier, I936). The pronotum in Tetrigidae is strongly elongated, covering the whole or the greater part of the body, which is never the case in Acridoidea.

2. The structure of the phallic complex is entirely different. In Tetrigidae the epiphallus is absent; the pseudosternite, described by Walker (I922), cannot be regarded as homologous with the epiphallus of Acridoidea and probably represents a structure of a different origin. The cingulum, in the same meaning as in Acridoidea, is also absent. The penis is directed towards the anterior end of the body, whereas in Acridoidea it is always directed towards the posterior end. The family Trigonopterygidae is the only exception ; in it the penis is directed towards the anterior end, as a secondary phenomenon, the whole phallic complex being in a reversed position ; the ventral part being in a dorsal position and the dorsal part ventral (see Dirsh, I956.) The whole phallic organ in Tetrigidae is covered above with valves, which are absent in Acridoidea.

3. The elytra in Tetrigidae are strongly shortened, scale-like, while the wings are fully developed (though there are some apterous species). This never occurs in Acridoidea. The hind wing has a strongly reduced remigium, a relatively large vannus and unbranched main veins (Ragge, I955).

4. The tympanal organ is always absent in Tetrigidae. In Acridoidea, except a few families, it is present.

5. The anterior and middle tarsi of Tetrigidae consist of two segments and only the hind tarsus is three-segmented, while in Acridoidea all tarsi are always threesegmented.

6. Arolia are absent in Tetrigidae but always present in Acridoidea.

All these characters separate Tetrigidae from Acridoidea definitely and it is probable that the internal anatomy, when studied, will provide further important features of difference.

\section{TAXONOMIC CHARACTERS}

The attitude of taxonomists of the last and the beginning of this century towards classification of Acridoidea was to regard the genera and species as being related if they resembled each other in general appearance. However, such resemblance, often due to convergent adaptation to habitat and mode of life, is often deceptive, and many superficially similar genera proved to be quite unrelated when their external and some internal characters were compared in detail.

For example, the genera Acrida and Truxalis, which are superficially similar and were usually regarded as closely related, actually belong to clearly distinct subfamilies. Mesopsis and Mesopsera were also regarded as related, but the first

${ }^{1}$ Only the family Tetrigidae, not the whole suborder Tetrigoidea, is compared here with Acridoidea, since it is only this family, not the whole suborder, that was regarded as belonging to the Acridoidea. 
belongs to the subfamily Truxalinae and the second to Hemiacridinae. Batrachotetrigini were regarded as a part of Oedipodinae, to which they are superficially similar, but it is undisputed now that they belong to the family Pamphagidae.

The characters used for differentiation of families and subfamilies will be seen from the diagnoses and the table below, but a few explanatory remarks are necessary.

Chopard (I920) was the first to introduce the structure of the internal, mainly male, genitalia for the purpose of systematics. Since then genitalia have been used by a few other authors, as supplementary characters for the differentiation of species and genera. On a wider scale, for characterizing higher groups, male genitalia were used by Roberts (I94I), Uvarov (I943) and Dirsh (I956) and the female genitalia by Slifer (I939-43) and Dirsh (I957).

It may be suggested that the male genitalia represent one of the most reliable characters for the classification of higher taxonomic units, because they are less subject to the adaptive changes of the organism in changing environmental conditions than are the external structures.

For the differentiation of families the phallic complex is certainly most reliable and can be used as a single character. Up to the present time, no intermediate forms which might suggest transition from one family to another, have been found. It serves by itself to define some subfamilies, e.g. Euryphyminae, Calliptaminae, Eremogryllinae and Hemiacridinae, or it may be used as an auxiliary character. It displays a considerable diversity at the generic level and sometimes may be used for separation of species.

Other internal characters, e.g. the Comstock-Kellogg glands, alimentary canal, malpighian tubes, nervous system, internal skeleton, muscles, chromosomes, etc., may offer characters of value, but too few species have been studied in these respects for use to be made of them for taxonomic purposes at present.

The second important character recently introduced into the systematics of Acridoidea is the stridulatory mechanism. The ability of some grasshoppers to produce sounds detectable by the human ear was known from time immemorial, but the relations between the types of the sound-producing mechanisms and taxonomy were not stressed until comparatively recently. A variety of structures serving for stridulation has been described (Uvarov, I928, I942; Chopard, I938; Henry, I942 ; Burtt, I946 ; Kevan, I953-54 ; Dirsh, I955) and it is clear that they have important taxonomic value. Such structures exist in the majority of families and subfamilies, while their regular absence in others also appears characteristic.

In the majority of cases, the stridulatory mechanism provides additional taxonomic evidence for systematic groups, based on other characters. In some groups it even provides the main character when others are less adequate or are obscured by convergence, general reduction, etc.

The most important point is the principle of the structure of the stridulatory mechanism. For example: the males of Tanaoceridae, Pneumoridae and Xyronotidae have a combination of ridges on the sides of the third abdominal tergite with a serrated or non-serrated ridge on the internal side of the hind femora. In the majority of subfamilies of the family Acrididae the mechanism is based on the friction between the elytra and hind legs. In Truxalinae and Eremogryllinae this 
TABLE II.-Families and their Main

Internal characters

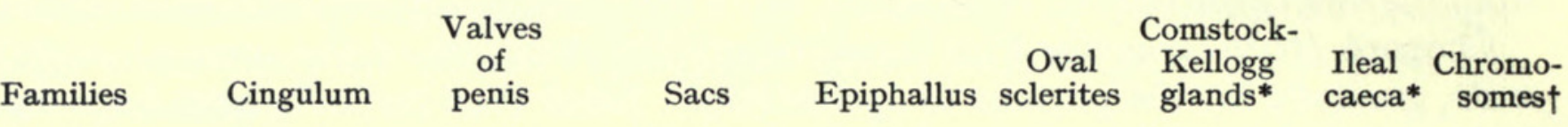

\begin{tabular}{|c|c|c|c|c|c|c|c|c|}
\hline Eumastacidae & . Absent & $\begin{array}{c}\text { Single } \\
\text { sclerited }\end{array}$ & $\begin{array}{c}\text { Ejaculatory } \\
\text { sac without } \\
\text { pockets }\end{array}$ & Variable & - & - & + & Small \\
\hline Proscopiidae & - Primitive & $\begin{array}{c}\text { Single } \\
\text { sclerited }\end{array}$ & Ditto & $\begin{array}{l}\text { Bridge- } \\
\text { shaped }\end{array}$ & - & - & - & ", \\
\hline Tanaoceridae & ," & $?$ & $?$ & $\begin{array}{l}\text { Plate- } \\
\text { shaped }\end{array}$ & - & $?$ & $?$ & ? \\
\hline Pneumoridae & ," & $\begin{array}{l}\text { Paired } \\
\text { not } \\
\text { divided }\end{array}$ & $\begin{array}{c}\text { Ejaculatory } \\
\text { sac without } \\
\text { pockets }\end{array}$ & Ditto & - & ? & $?$ & Small \\
\hline Xyronotidae & , & $?$ & $?$ & , & - & $?$ & $?$ & ", \\
\hline Trigonopterygidae & ", & $\begin{array}{c}\text { Paired } \\
\text { divided }\end{array}$ & $\begin{array}{l}\text { Ejaculatory } \\
\text { sac without } \\
\text { pockets }\end{array}$ & ", & - & ? & $?$ & ", \\
\hline Charilaidae . & $\begin{array}{c}\text { Differen- } \\
\text { tiated }\end{array}$ & Ditto & Ditto & ," & - & $?$ & $?$ & ? \\
\hline Pamphagidae & , & ", & , & ", & - & - & - & Large \\
\hline Lathiceridae . & $\begin{array}{c}\text { Shield- } \\
\text { like }\end{array}$ & , & ", & $\begin{array}{l}\text { Bridge- } \\
\text { shaped }\end{array}$ & + & $?$ & $?$ & ? \\
\hline Pyrgomorphidae & - $\begin{array}{c}\text { Capsule- } \\
\text { like }\end{array}$ & $\begin{array}{l}\text { Paired } \\
\text { not } \\
\text { divided }\end{array}$ & , & Ditto & - & - & - & Large \\
\hline Ommexechidae & $\begin{array}{c}\text { Differen- } \\
\text { tiated }\end{array}$ & Ditto & $\begin{array}{c}\text { Ejaculatory } \\
\text { sac with } \\
\text { pockets }\end{array}$ & $\begin{array}{l}\text { Bridge- } \\
\text { shaped with } \\
\text { separated } \\
\text { lateral } \\
\text { plates }\end{array}$ & + & + & - & Small . \\
\hline Pauliniidae . & . Ditto & $\begin{array}{l}\text { Paired } \\
\text { divided }\end{array}$ & Ditto & Ditto & + & + & $?$ & ", \\
\hline Lentulidae . & , & $\begin{array}{l}\text { Paired } \\
\text { not } \\
\text { divided }\end{array}$ & $\begin{array}{c}\text { Ejaculatory } \\
\text { sac without } \\
\text { pockets }\end{array}$ & $\begin{array}{l}\text { Bridge- } \\
\text { shaped }\end{array}$ & + & - & $?$ & ", \\
\hline Acrididae & , & $\begin{array}{l}\text { Paired } \\
\text { divided } \\
\text { or } \\
\text { flexured }\end{array}$ & Ditto & Variable & + & + or - & - & Medium \\
\hline
\end{tabular}

* According to Slifer (1939-43).

$\dagger$ According to Helwig (1958).

type of mechanism is represented by the sharpened veins of the elytra and a serration (with articulated or non-articulated pegs) on the internal side of the hind femora. In the group Oedipodini of Acridinae it consists of a serrated intercalary vein of the elytra and a sharp ridge on the internal side of the hind femora. In Romaleinae it is represented by serrated veinlets on the hind wings and sharpened veins on the lower surface of the elytra. In Hemiacridinae it is a combination of the thickened 
Characters $(+$ Present, - Absent $)$

External characters

\begin{tabular}{|c|c|c|c|c|c|c|c|c|c|}
\hline $\begin{array}{l}\text { Abdomino- } \\
\text { femoral } \\
\text { stridulatory } \\
\text { mechanism }\end{array}$ & $\begin{array}{l}\text { Tube- } \\
\text { like } \\
\text { pro- } \\
\text { thorax }\end{array}$ & $\begin{array}{l}\text { Hind } \\
\text { legs }\end{array}$ & $\begin{array}{l}\text { Brunner's } \\
\text { organ }\end{array}$ & $\begin{array}{l}\text { Basal } \\
\text { lobes of } \\
\text { hind } \\
\text { femur }\end{array}$ & $\begin{array}{l}\text { Fasti- } \\
\text { gial } \\
\text { furrow }\end{array}$ & $\begin{array}{l}\text { Antennal } \\
\text { grooves }\end{array}$ & $\begin{array}{l}\text { Median } \\
\text { carina } \\
\text { of } \\
\text { pronotum }\end{array}$ & $\begin{array}{l}\text { Elytra } \\
\text { and } \\
\text { wings }\end{array}$ & Tympanum \\
\hline - & - & Saltatorial & + & Variable & + or - & - & $\begin{array}{l}\text { Single or } \\
\text { absent }\end{array}$ & + or - & - \\
\hline - & + & $\begin{array}{l}\text { Almost } \\
\text { cursorial }\end{array}$ & - & $\begin{array}{c}\text { Lower lobe } \\
\text { longer }\end{array}$ & - & - & Ditto & Mainly & - \\
\hline+ & - & Saltatorial & + & Ditto & - & - & Single & - & - \\
\hline+ & - & $\begin{array}{l}\text { Almost } \\
\text { cursorial }\end{array}$ & - & ," & + & - & , & + & - \\
\hline+ & - & Saltatorial & + & $\begin{array}{l}\text { Lower lobe } \\
\text { shorter }\end{array}$ & + & - & ," & - & - \\
\hline - & - & ," & + & Ditto & + & - & ", & + & - \\
\hline- & - & ," & + & $\begin{array}{c}\text { Lower lobe } \\
\text { longer }\end{array}$ & + & - & Double & + & + \\
\hline- & - & ," & + & Ditto & + & - & $\begin{array}{l}\text { Single or } \\
\text { absent }\end{array}$ & + or - & Normally + \\
\hline - & - & ," & + & ," & + & + & Ditto & - & - \\
\hline- & - & ," & + & , & + & - & ," & + or - & Normally + \\
\hline - & - & ," & + & $\begin{array}{l}\text { Of equal } \\
\text { length }\end{array}$ & + & - & , & + or - & + or - \\
\hline- & - & ," & + & $\begin{array}{l}\text { Lower lobe } \\
\text { shorter }\end{array}$ & - & - & Single & + & + \\
\hline- & - & ," & + & Ditto & - & - & $\begin{array}{l}\text { Single or } \\
\text { absent }\end{array}$ & - & - \\
\hline- & - & , & + & $\begin{array}{l}\text { Lower lobe } \\
\text { shorter or } \\
\text { both of } \\
\text { equal length }\end{array}$ & - & - & Ditto & + or - & + or - \\
\hline
\end{tabular}

veinlets of the elytra with the spines and spurs of the hind tibiae. There are other main types of the mechanism, and their modifications in some genera of the known subfamilies and families may provide useful auxiliary characters.

It is necessary to bear in mind that in some genera and species the stridulatory mechanism may be lost or reduced (particularly in females), but its loss is a secondary phenomenon often connected with the reduction or loss of wings. It should be 
noted also that analogous structures may appear as an exception in unrelated genera of different subfamilies and families, but this happens with almost every external character. As an example of such analogous development, the serration on the internal side of the hind femora in the two South American genera Atrachelacris and Leiotettix of the Catantopinae may be cited. The serration is somewhat similar to that in Truxalinae, but it is not accompanied by the specialization of the veins of the elytra. The genera nearest to Atrachelacris and Leiotettix have no serration at all.

At the present stage of knowledge of Acridoidea it is not possible to estimate the phylogenetic value of the majority of external morphological characters; even their purpose is unknown. In consequence it is not possible to say that any external character is more, or less, important than any other. The way they are used in classification is mainly a matter of convenience. Thus although the stridulatory mechanism is not necessarily more valuable than the other external characters, it offers useful diagnostic features which cannot be ignored. The biological significance of stridulation is great, since it is largely connected with sexual activity, which makes it important for the survival of the species.

A further useful character, introduced by Uvarov (I943), is the structure of the hind femur. It is useful in differentiation of certain families and subfamilies (see Tables II and III). The lower basal lobe of the hind femur may be longer or shorter than, or equal to, the upper. This character, however, has no absolute value, since intermediate forms occur in unrelated groups, but it is valuable if considered in combination with other features.

The next important character is a deep, short, median furrow on the apex of the fastigium of the vertex, which is, in most cases, a direct continuation of the sulcus of the frontal ridge. Whether it is homologous with the epicranial suture of other insects or is a secondary phenomenon is not relevant here. This furrow, first noticed by Stål (I876), and later mentioned by Rehn (I938), as characteristic for Pamphagidae, was introduced as a character of great value by Uvarov (I943) for that family and Pyrgomorphidae. Now it can be extended to Trigonopterygidae, Charilaidae, Lathiceridae, Xyronotidae and Pneumoridae. It is, however, not an absolute character, since in some Pamphagidae and others in which the head approximates to globular, it has a secondary tendency to disappear, while it occasionally appears in quite unrelated genera of Acrididae.

Helwig (I958) suggested, as a taxonomic character for families, the size of chromosomes, dividing the families into groups, with small, medium and large chromosomes (see Table II). It is difficult to estimate the real value of this character since too few genera have been studied.

The following general considerations are used here as a basis for the division of Acridoidea into families and subfamilies. A family is regarded as a group of genera possessing characters which do not occur in other groups or some of which occur in different combinations; there are no living genera intermediate between the families. A subfamily is regarded as a group of genera with one or more convenient characters, or a combination of characters, which do not normally occur in other groups of genera of the family, but are not exclusive, so that the occurrence of intermediate genera is possible. 
LIST OF FAMILIES

\section{Order Orthoptera}

\section{Suborder Acridoidea}

\begin{tabular}{|c|c|c|}
\hline & & Eumastacidae \\
\hline & , , & Proscopiidae \\
\hline & , & Tanaoceriidae \\
\hline & ,", & Pneumoridae \\
\hline & , , & Xyronotidae \\
\hline & , , & Trigonopterygidae \\
\hline & , & Charilaidae \\
\hline
\end{tabular}

$\begin{array}{lll}\text { 8. } & \text { Family } & \text { Pamphagidae } \\ \text { 9. } & \text {, } & \text { Lathiceridae } \\ \text { I0. } & \text {, } & \text { Pyrgomorphidae } \\ \text { I I. } & \text { ", } & \text { Ommexechidae } \\ \text { I2. } & \text { ", } & \text { Pauliniidae } \\ \text { I3. } & \text { ", } & \text { Lentulidae } \\ \text { I4. } & \text {, } & \text { Acrididae }\end{array}$

Key to Families

The following key to families is based on external characters alone, but it must be remembered that in some cases male genitalia provide the decisive character and these are mentioned in the respective family diagnoses.

I (2) Frons mostly flattened. Cubital vein of elytron and medial vein of hind wing unbranched. Antenna, on lower apical part, usually with small tubercle (antennal organ). Basal segment of hind tarsus with serrated margins, or with basal, or apical, or both external teeth or at least with a basal external tubercle

Eumastacidae

2 (I) Frons of variable shape. Cubital vein of elytron and medial vein of hind wing usually branched. Antennal organ mostly absent. Basal segment of hind tarsus never serrated, never with teeth or tubercle.

3 (4) Body stick-like. Prothorax tube-like, with lower margins of lateral lobes of pronotum fused with prosternum. Brunner's organ absent . Proscopiidae

4 (3) Body usually not stick-like. Prothorax not tube-like, with lower margins of lateral lobes of pronotum not fused with prosternum. Brunner's organ present (in Pneumoridae vestigial or absent).

5 (10) Abdomino-femoral stridulatory mechanism, represented by ridges on the third abdominal tergite and a ridge on internal side of hind femur, present in males.

6 (7) Antenna in male longer than, in female about as long as, body. Abdominal part of stridulatory mechanism represented by curved cylindrical ridge covered with fine transverse ridgelets; ridge on internal side of hind femur not serrated

Tanaoceridae

7 (6) Antenna in both sexes much shorter than body. Abdominal part of stridulatory mechanism represented by a row of short, sharp ridges ; ridge on internal side of hind femur serrated.

8 (9) Body stout, in males strongly inflated. Head with flattened vertical frons. Brunner's organ vestigial or absent. Male macropterous, female with reduced wings . . . . . . . . . . . Pneumoridae

9 (8) Body slender, compressed. Head acutely conical. Brunner's organ present. Completely apterous . . . . . .

Io (5) Abdomino-femoral stridulatory mechanism absent.

II (22) Fastigial furrow present.

I2 (13) Lower basal lobe of hind femur shorter than the upper. Elytron widening

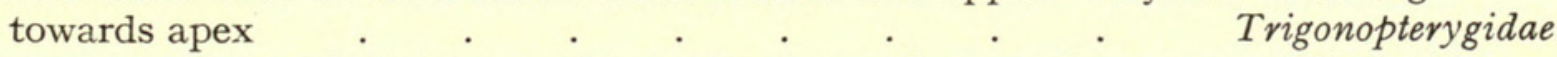

I3 (I2) Lower basal lobe of hind femur longer than or as long as the upper. Elytron not widening towards apex.

I4 (2I) Lower basal lobe of hind femur longer than the upper. 
I5 (I6) Antennal grooves present.

Lathiceridae

I6 (I5) Antennal grooves absent.

I7 (I8) Median carina of pronotum double

Charilaidae

I 8 (I7) Median carina of pronotum single or absent.

I9 (20) Head of variable shape, but not acutely conical. Apical fastigial areas absent. Krauss's organ mostly present

20 (I9) Head acutely conical, with regularly incurved frons. Apical fastigial areas mostly present. Krauss's organ absent . . . . . Pyrgomorphidae

2 I (I4) Lower basal lobe of hind femur as long as upper one . . . . Ommexechidae

22 (I I) Fastigial furrow absent.

23 (24) Completely apterous. Tympanum absent. . . . . . . . Lentulidae

24 (23) Fully winged or with reduced wings, cr apterous. Tympanum usually present, if absent, then body depressed.

25 (26) Medial vein of elytron unbranched. Ocelli very large. Hind tibia with strongly expanded lateral margins . . . . . . Pauliniidae

26 (25) Medial vein of elytron usually branched. Ocelli comparatively small. Lateral margins of hind tibia not expanded, slightly expanded or rarely strongly expanded

\section{Family Eumastacidae}

(Text-figs. I, 2)

\section{Type genus : Eumastax Burr, I899}

Body of variable shape. Head of variable shape, with frons mostly flattened. Antenna on lower apical part usually with tubercle-like antennal organ. Prosternal process absent. Lower basal lobe of hind femur longer or shorter than upper one. Brunner's organ present. Basal segment of hind tarsus with serrated upper margins or with basal, or apical, or with both external teeth, or at least with basal external tubercle. Elytra and wings fully developed, reduced or absent; cubital vein of elytra and medial vein of hind wing unbranched. Ectophallus relatively large, not forming cingulum. Endophallus small, with single-sclerited penis. Epiphallus of variable shape. Oval sclerites absent. Ileal caeca present. Stridulatory mechanism not known.

In the structure of the phallic complex the family Eumastacidae differs so strongly from other families of Acridoidea that they can hardly be regarded of the same rank. However, temporarily, it is advisable to keep them in their present status until more data are available. A sac-like ectophallus without a cingulum is possibly a primitive feature, which does not occur in other families; on the other hand, sometimes the complicated structure of the ectophallus indicates a high specialization but in a different direction from that in other Acridoidea. The primitiveness is suggested also by the small, and in most cases, comparatively simple, endophallus, with penis of a single sclerite. In higher Acridoidea the endophallus is complicated and, except in Proscopiidae, always with a two-sclerited penis.

Another internal character, which according to Slifer (I944), occurs only in Eumastacidae, is the presence of ileal caeca in the form of six appendices attached to the hindgut of the alimentary canal. 

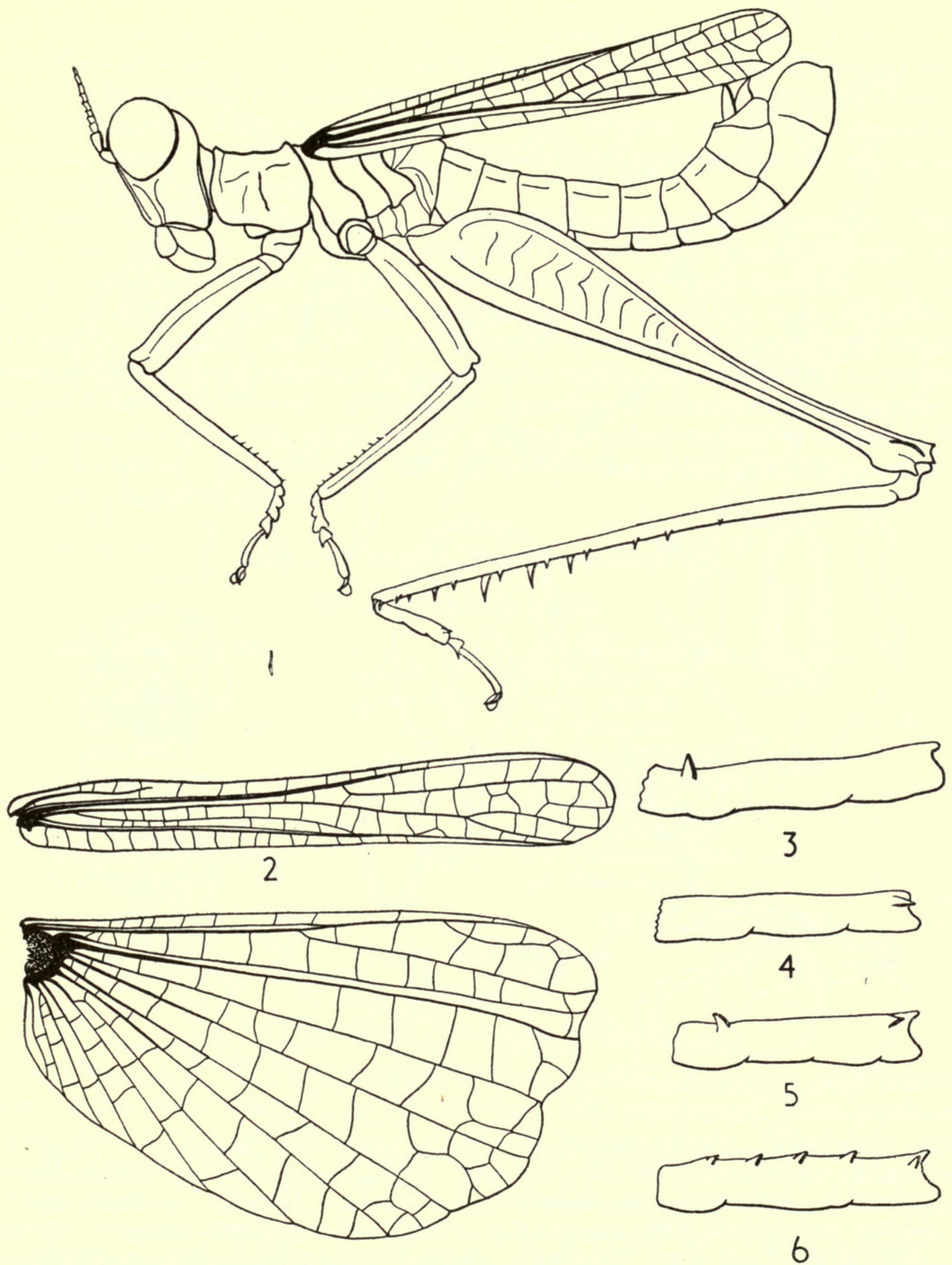

FIG. I. I. Eumastax surda Burr, whole insect. 2. The same, elytron and wing. 3-6. Basal tarsal segment. 3. Biroella. 4. Eumastax. 5. Pseudothericles. 6. Chorotypus. 

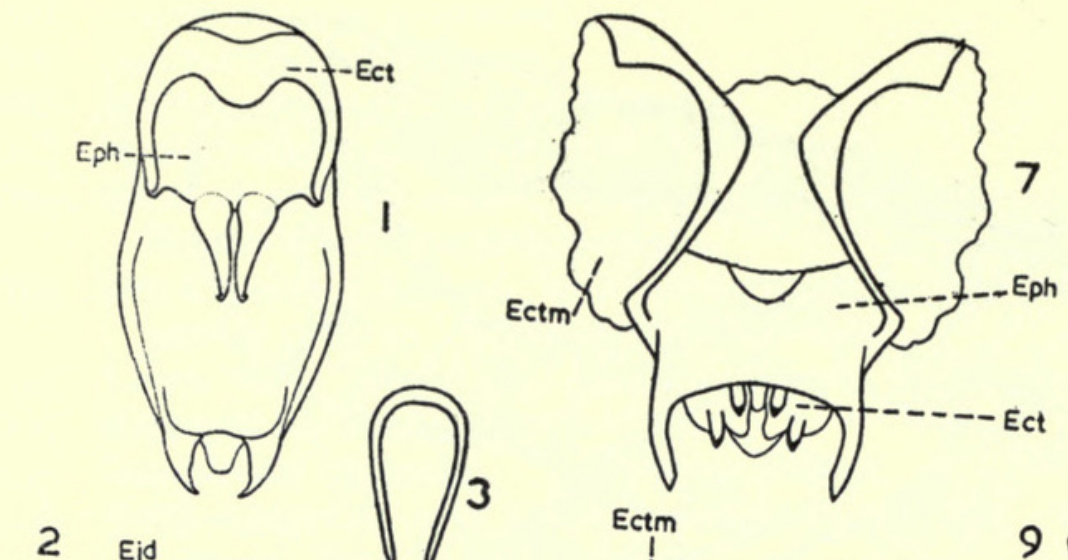

13
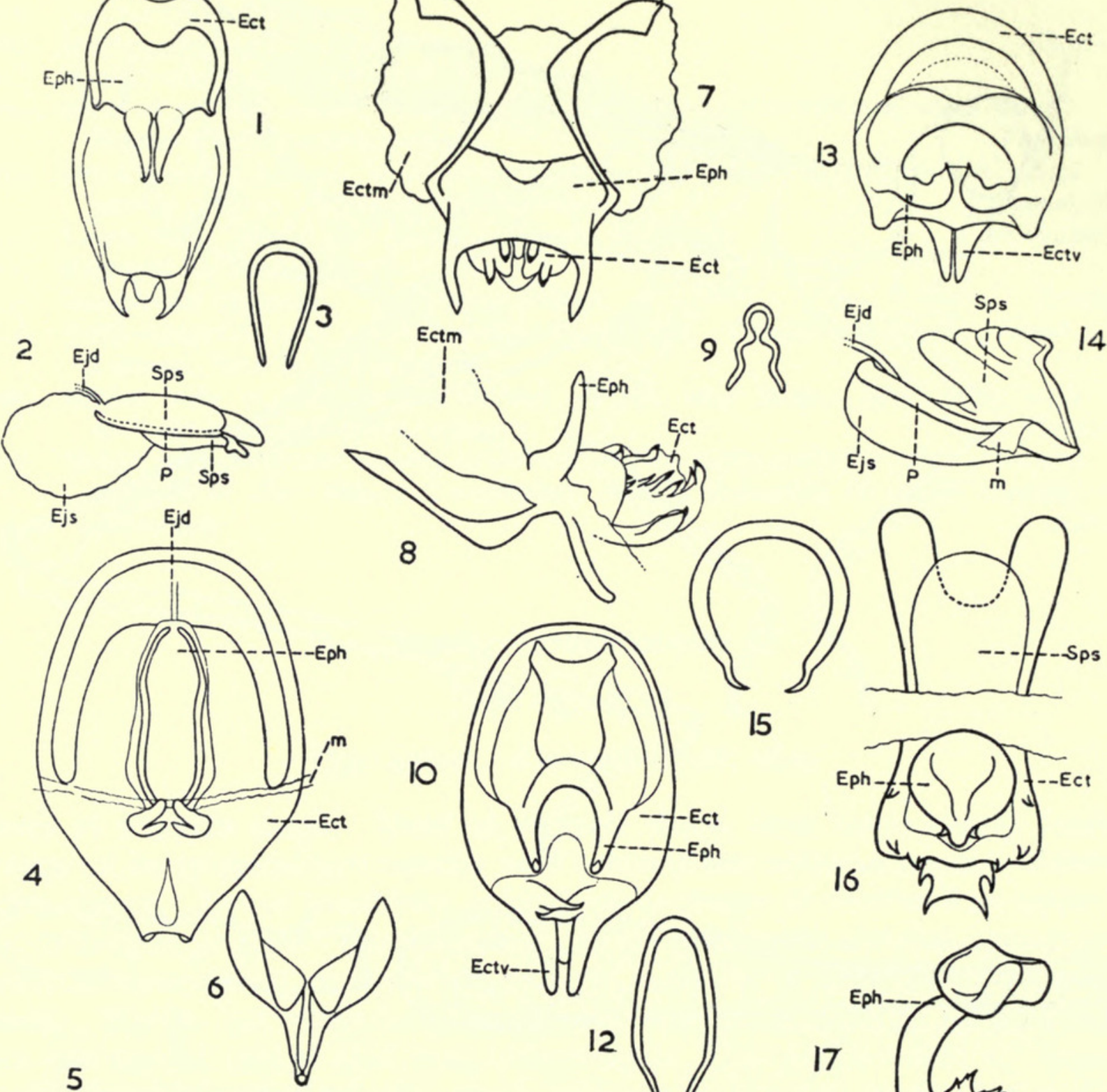

8
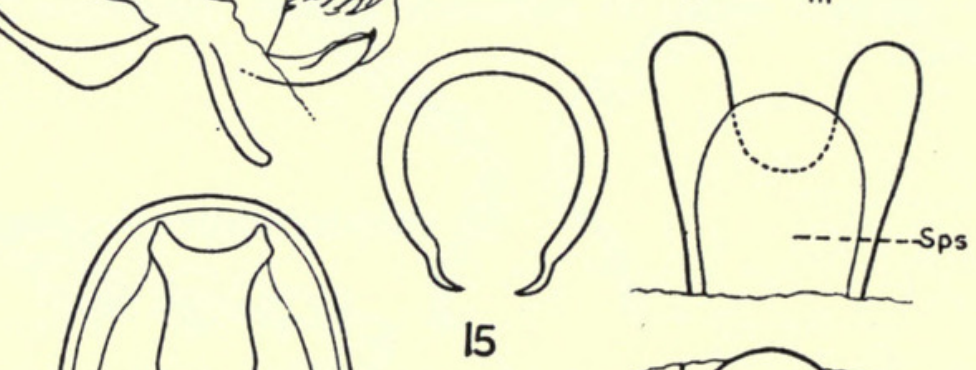

10

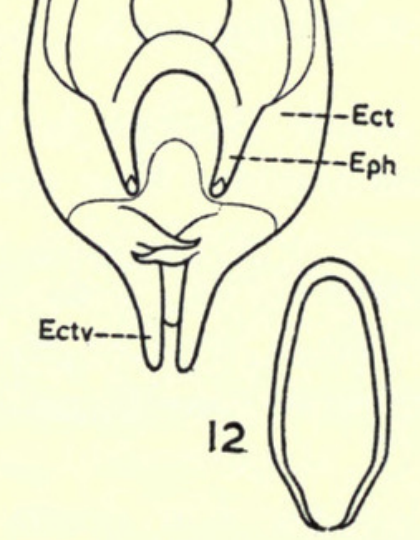

15
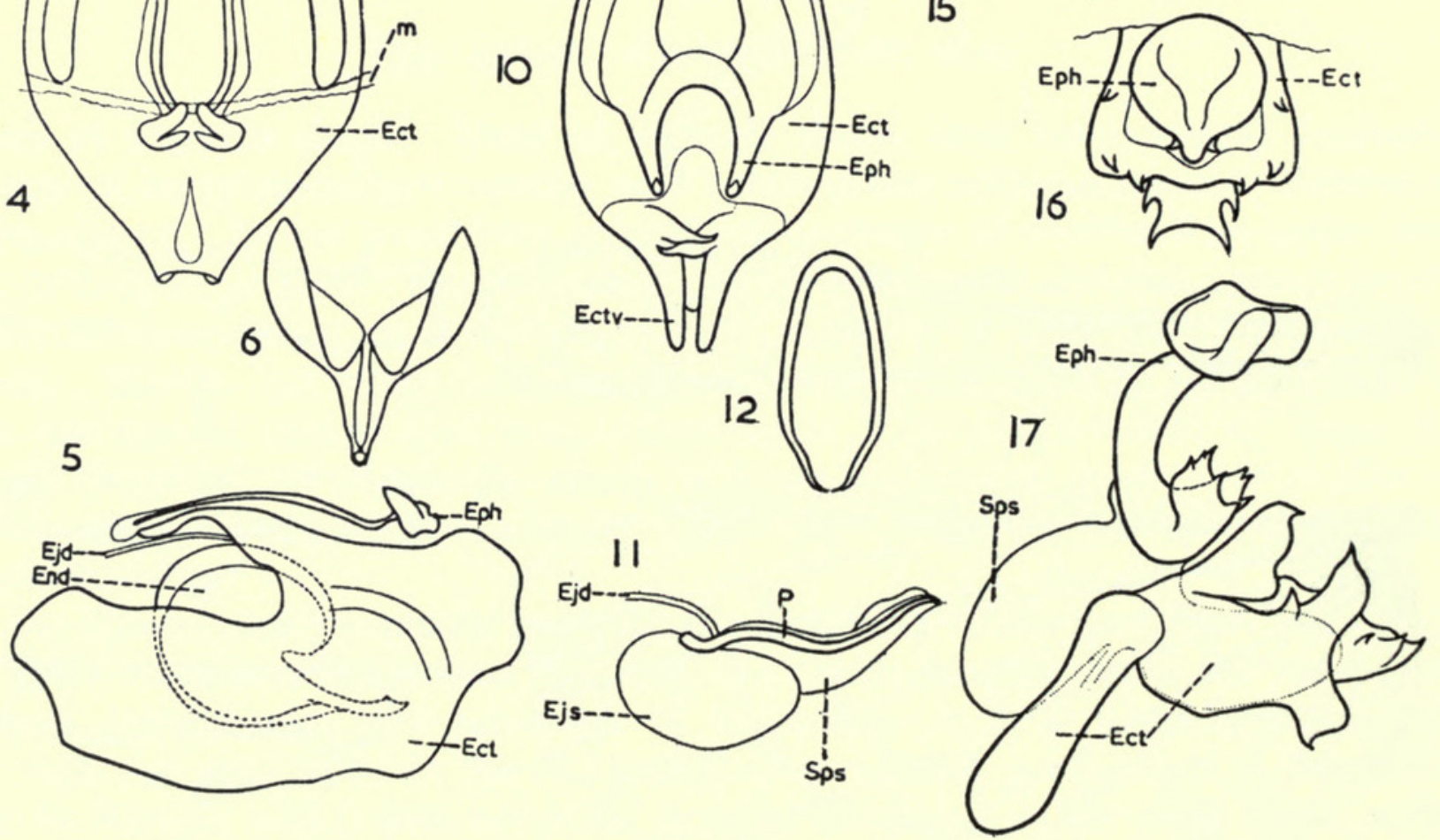

FIg. 2. Examples of the phallic complex in Eumastacidae. I-3. Moraba sp. I. Phallic complex from above. 2. The same in profile. 3. Penis from above. 4-6. Euschmidtia burri Uv. 4. Phallic complex from above. 5. The same in profile. 6. Penis from above. 7-9 Erucius dimidiatipes I. Bol. 7. Phallic complex from above. 8. The same in profile. 9. Penis from above. Io-I2 Biroella gracilis $C$. Bol. Io. Phallic complex from above. II The same in profile. I2. Penis from above. I3-15. Gomphomastax clavata (Ostr.). I3. Phallic complex from above. I4. The same in profile. I5. Penis from above. I6, I7. Evianthus guttatus (Westw.). I6. Phallic complex from above. I7. The same in profile. 
The external characters of value are the unbranched cubital vein of the elytron and the unbranched median vein of the hind wing (Ragge, 1955). However, the Eumastacidae share the former character with Ommexechidae, Pauliniidae and some Pyrgomorphidae, and it occurs also in some Catantopinae with shortened elytra.

The presence of teeth or a tooth, or at least a tubercle, on the basal segment of the hind tarsus is a character which occurs only in Eumastacidae and not in any other family of Acridoidea.

Rehn (I948) divided the family Eumastacidae into seventeen subfamilies. Since then, one subfamily (Tanaocerinae) has been removed and raised to family rank (Dirsh, I955) and one new subfamily Socotrellinae Popov, I957, described. In I958 Rehn and Grant erected three more subfamilies. However, the main character of the family, the phallic complex, is so divergent in certain subfamilies that a wider separation than at the subfamily level appears probable, while some other subfamilies suggest closer interrelations. It would be premature to attempt a reclassification of them, because only a few of the known genera have been studied in respect of the phallic complex. At present it is more practical to regard the group temporarily as one very heterogeneous family.

\section{LIST OF SUBFAMILIES OF EUMASTACIDAE}

(Alphabetical order)
I. Biroellinae
2. Chininae
3. Chorotypinae
4. Episactinae
5. Eruciinae
6. Espagnolinae
7. Eumastacinae
8. Euschmidtiinae
9. Gomphomastacinae
10. Malagassinae
II. Mastacideinae
12. Miraculinae
13. Morabinae
14. Morseinae
15. Paramastacinae
16. Pseudomastacinae
I7. Socotrellinae
I8. Teicophryinae
19. Temnomastacinae
20. Thericleinae

\section{Family Proscopiidae}

(Text-fig. 3)

Type genus: Proscopia Klug, I820

Body stick-like. Basi-occipital slit of head present. Pronotum with reduced lateral lobes, lower margins of which are fused with prosternum, whole prothorax representing a tube-like structure. Prosternal process absent. Elytra and wings absent (rarely present but strongly reduced). Tympanum absent. Hind legs almost cursorial. Brunner's organ absent. External apical spine of hind tibia present. Phallic complex with differentiated ectophallus; cingulum primitive. Endophallus strongly specialized; penis single-sclerited. Epiphallus bridge-shaped ; oval sclerites absent. Stridulatory mechanism not found.

All the characters of Proscopiidae indicate absence of close relationship with any other known family. The loss or great reduction of the wings and the reduction of 
the hind legs to almost cursorial condition, and the absence of Brunner's organ, make comparisons more difficult. The phallic complex, with primitive cingulum and highly complicated endophallus, represents a blend of primitive and specialized characters but no other anatomical studies are available. The only suggestion which may be made is that the family represents a very early branch of unknown pre-acridoid stock, and is possibly remotely related to Eumastacidae.

Distributed in South America.

For scope of the family see Mello-Leitão, I939.

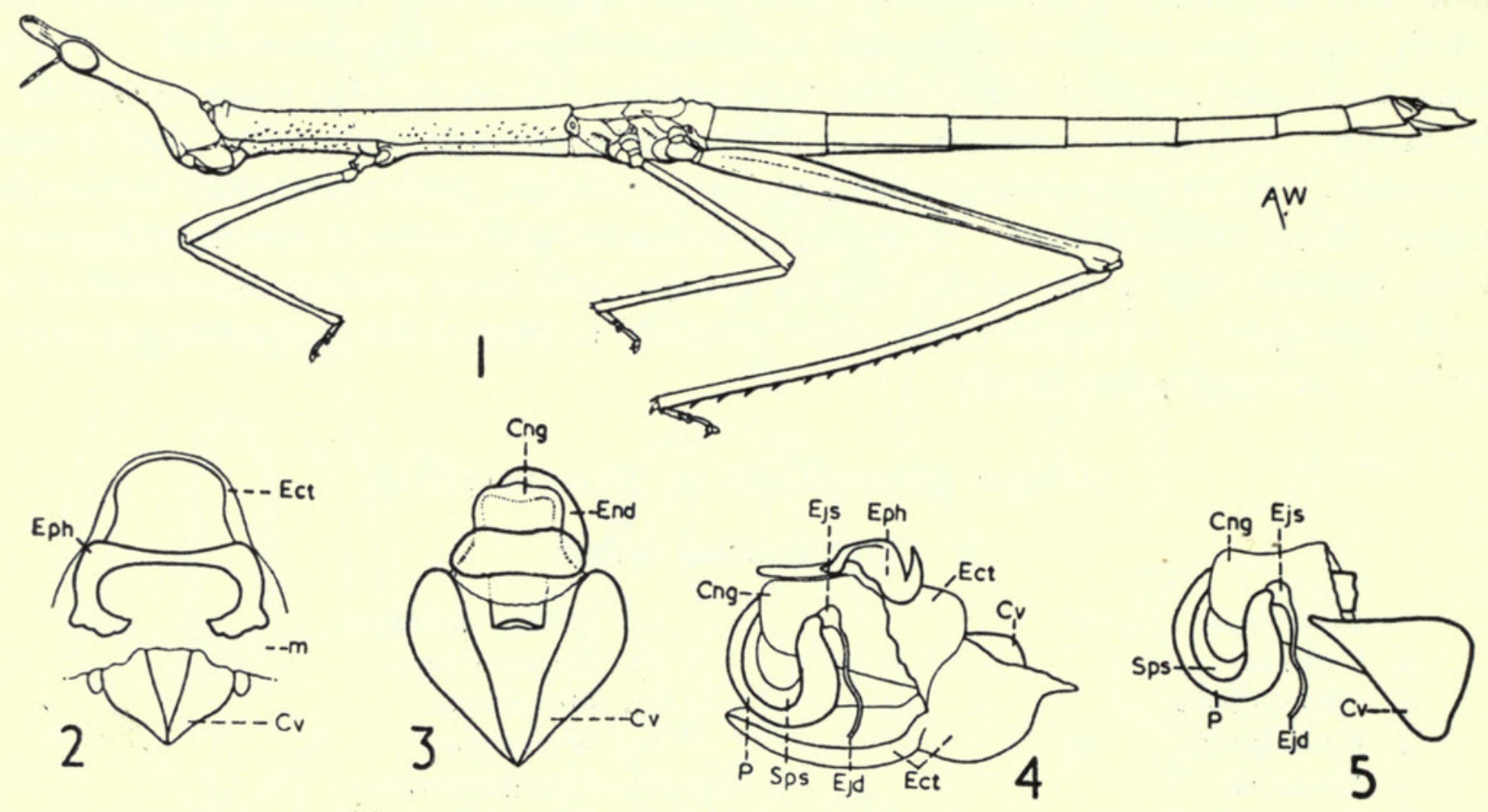

FIg. 3. Proscopia scabra Klug. I. Whole insect. 2-5. Phallic complex. 2. From above. 3. The same, but ectophallic membrane and epiphallus removed. 4. In profile. 5. The same, but ectophallic membrane and epiphallus removed.

\section{Family Tanaoceridae}

\section{(Text-fig. 4) \\ Type genus : Tanaocerus Bruner, I906}

Antenna in male longer, in female only slightly shorter than body. Head subspheroidal. Prosternal process absent. Elytra, wings and tympanum absent. On the sides of third abdominal tergite of male there is thick, cylindrical ridge, densely covered with fine transverse ridgelets (part of stridulatory mechanism). Lower basal lobe of hind femur longer than upper one. External apical spine of hind tibia present. Male subgenital plate composed of several separate sclerites, connected by membrane. Poorly developed cingulum of phallic organ present. Epiphallus disc-shaped, without ancorae and lophi. Oval sclerites absent.

When the first genus of the family, Tanaocerus Bruner, I906, was described it was referred to Evemobiinae. Later Rehn (I948) placed it and the second known genus into the family Eumastacidae and erected for them the subfamily Tanaocerinae. 
REVISION OF THE FAMILIES AND SUBFAMILIES OF $A C R I D O I D E A \quad 365$

When the peculiar stridulatory mechanism was found in the male Tanaocerus, the subfamily was raised to family rank (Dirsh, I955).

The differences of this family from Eumastacidae and other Acridoidea are extremely striking. The peculiar stridulatory mechanism, one part of which is a ridge covered with ridgelets on the sides of the third abdominal tergite and another part is a short, sharp ridge on the internal side of the hind femur, is shared only with Pneumoridae and Xyronotidae, with which there is otherwise no relationship. The

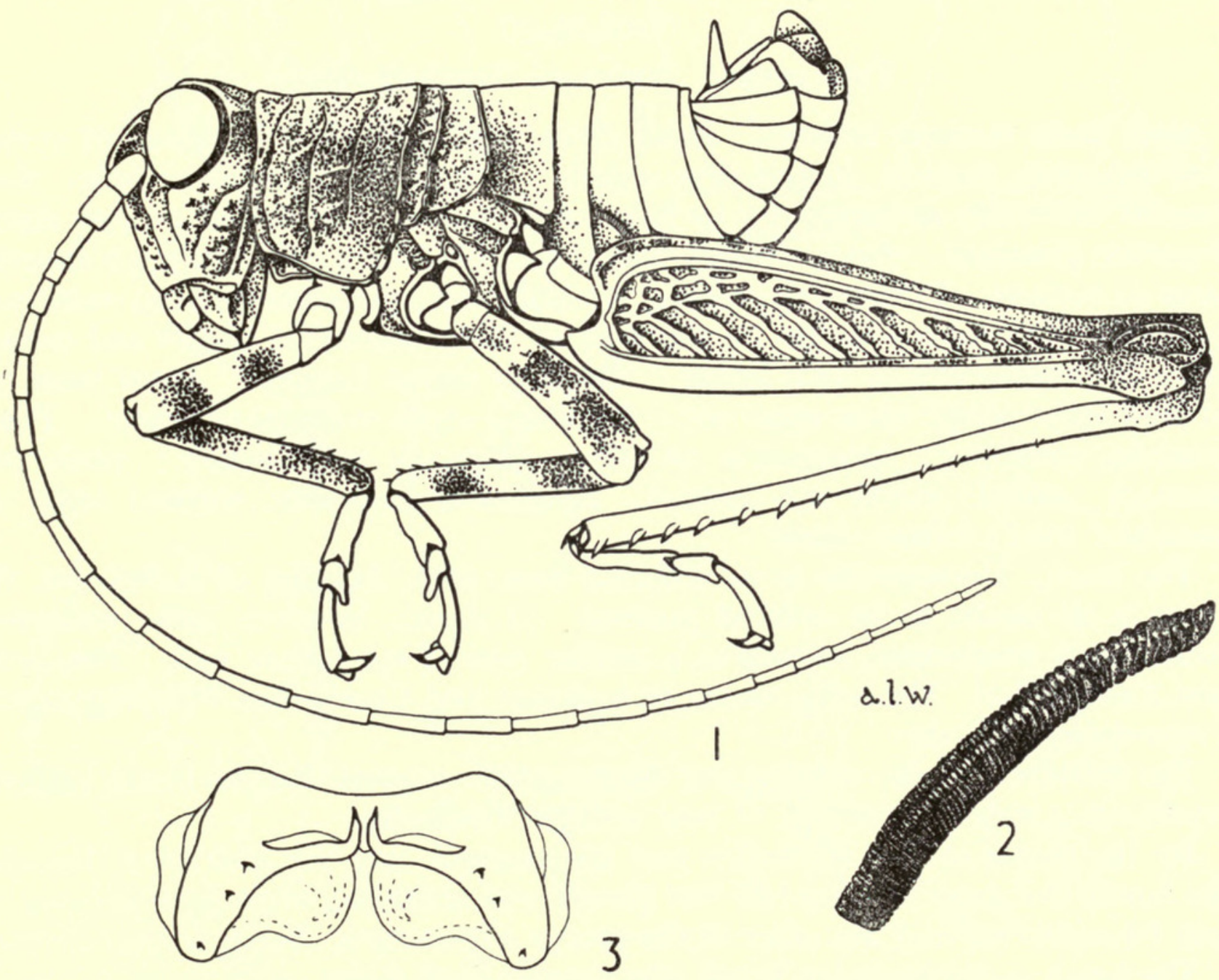

FIG. 4. Tanaocerus koebelei Bruner. I. Whole insect, male. 2. Abdominal part of the stridulatory mechanism. 3. Epiphallus.

Eumastacidae, to which Tanaoceridae was previously referred, have no stridulatory mechanism. A subspheroidal head, as in Tanaocerus, is not found in Eumastacidae. Such peculiarly long antennae as in Tanaocerus do not occur in any other family of Acridoidea. The peculiar structure of the male subgenital plate of Tanaocerus is also not found in other families.

The phallic complex of the family is not yet sufficiently studied, but the available data suggest that it is very characteristic. The presence of a primitive cingulum also suggests that Tanaoceridae differ widely from Eumastacidae, which have no cingulum. All these considerations indicate that the family Tanaoceridae is sharply different from other families of Acridoidea. 
The family occurs only in the south-west part of North America.

\section{List of known genera :}

I. Mohavacris Rehn, 1948

2. Tanaocerus Bruner, I906

\section{Family Pneumoridae}

\section{(Text-fig. 5) \\ Type genus : Pneumora Thunberg, I775}

Male body strongly inflated. Head short, with shortened fastigium of vertex; face flattened, vertical, frontal ridge absent; fine fastigial furrow present. Ocelli located internally or externally to bases of antennae. Prosternal process absent. Venation primitive ; elytra without vannal fold, hind wing with remigium almost as large as vannus. Tympanum absent. Stridulatory mechanism in male represented by a row of transverse ridges on the sides of third abdominal tergite and serrated ridge on internal side of hind femur. Hind legs almost cursorial ; lower basal lobe of hind femur longer than upper one ; Brunner's organ vestigial or absent. Phallic complex primitive; ectophallus sac-like; cingulum rudimentary; penis rudimentary, paired, valves not divided. Epiphallus plate-like, without lophi and ancorae ; oval sclerites absent.

The family Pneumoridae is so different from other families of Acridoidea, that there is no doubt of its isolated position. It shares, however, some features of stridulatory mechanism, as well as a similar type of epiphallus, with Tanaoceridae and Xyronotidae. The latter character is shared with Charilaidae, Pamphagidae and Trigonopterygidae also.

The primitive phallic complex and wing venation suggest that the family probably represents a surviving branch of very ancient Acridoidea.

By the shape of the epiphallus and spermatheca and the position of the ocelli the family is sharply divided into two groups, one consisting of the genera Pneumora and Physophorina and the other of the genera Physemacris, Bullacris and Prostalia.

The family is distributed in South Africa and in East Africa, as far north as Uganda.

List of known genera:

I. Bullacris Roberts, I94I

2. Physemacris Roberts, I94I

3. Physophorina Westwood, I874
4. Pneumora Thunberg, 1775

5. Prostalia I. Bolivar, I906

\section{Family Xyronotidae}

(Text-fig. 6)

Type genus: Xyronotus I. Bolivar, I884

Body laterally compressed. Head conical. Fastigial furrow present. Prosternal process present. Elytra, wings and tympanum absent. Lower basal lobe of hind 


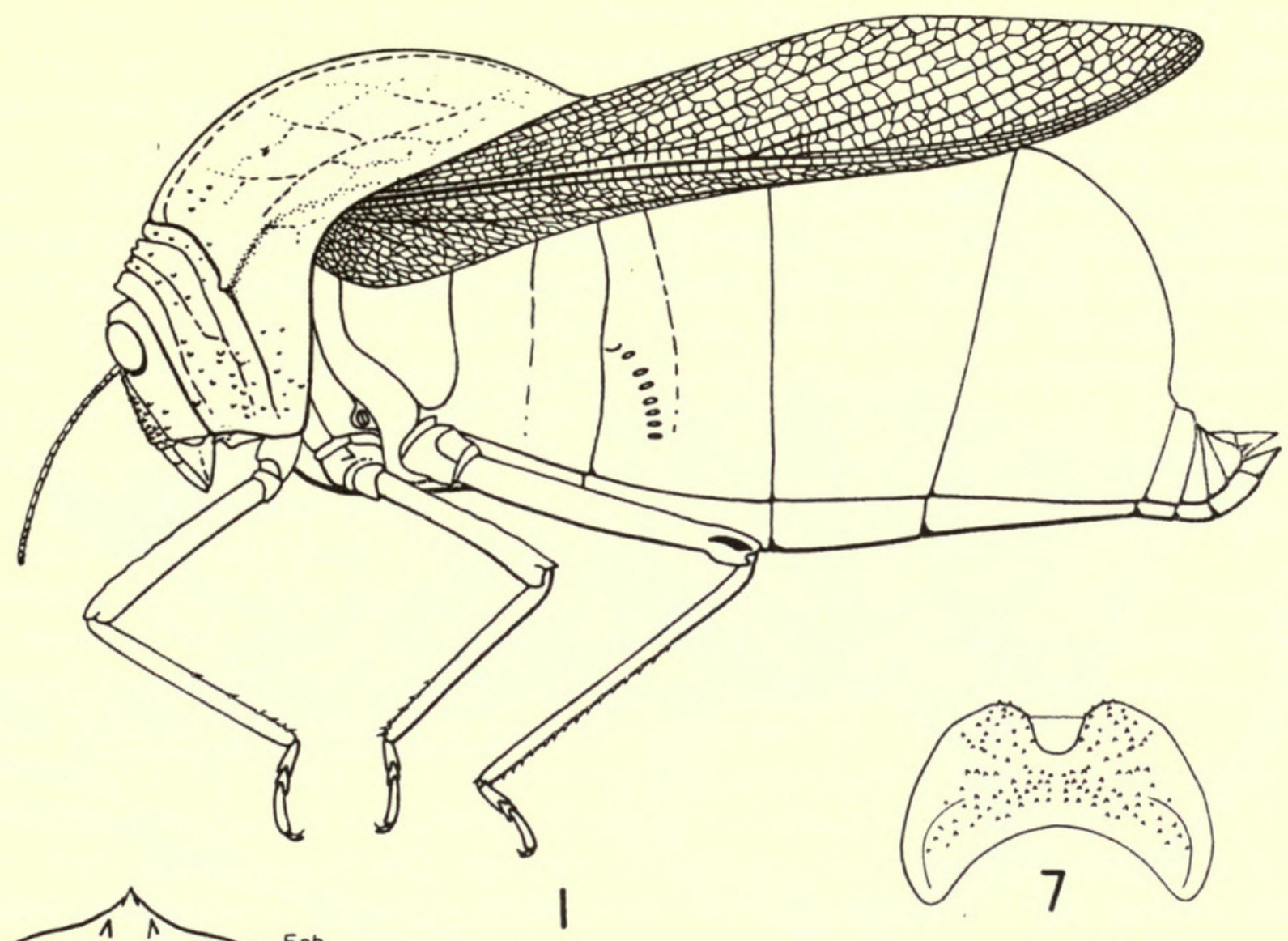

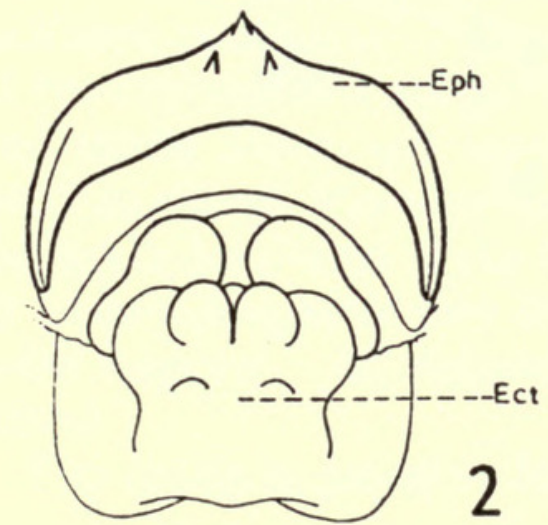

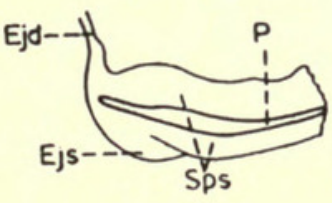

5

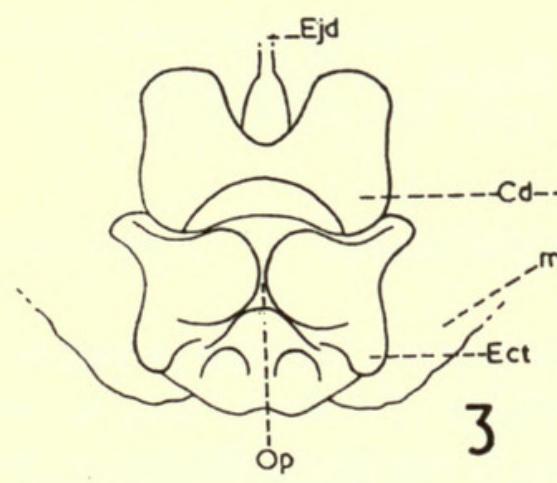

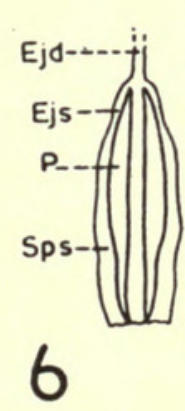

8

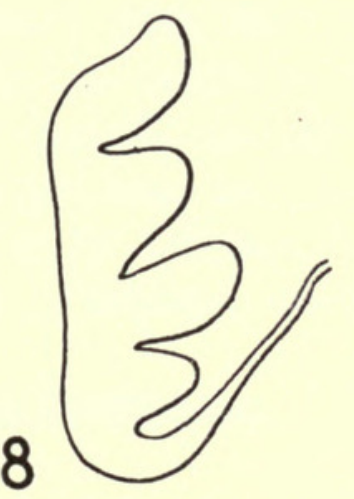

FIG. 5. I. Bullacris longicornis (St.), whole insect. 2-6. Phallic complex of Physemacris variolosa (L.). 2. From above. 3. Dorso-distal view. 4. In profile. 5. Endophallus in profile. 6. The same from above. 7. Epiphallus of Pneumora inanis (F.). 8-9. Spermatheca. 8. Pneumora inanis (F.). 9. Bullacris longicornis (St.). 
femur shorter than upper one. Brunner's organ present. External apical spine of hind tibia present. Sides of third abdominal tergite of male with a row of sharp, small, transverse ridges (part of stridulatory mechanism, the other part being serrated ridge on internal side of hind femur). Ectophallus weakly differentiated ; cingulum primitive. Epiphallus shield-like, without lophi and with pair of projections. Oval sclerites absent.

I. Bolivar (I909) placed the genus Xyronotus, which is the only one of the family, into "Sectio Xyronoti" of the family Pyrgomorphidae. Kevan (I952) regarded

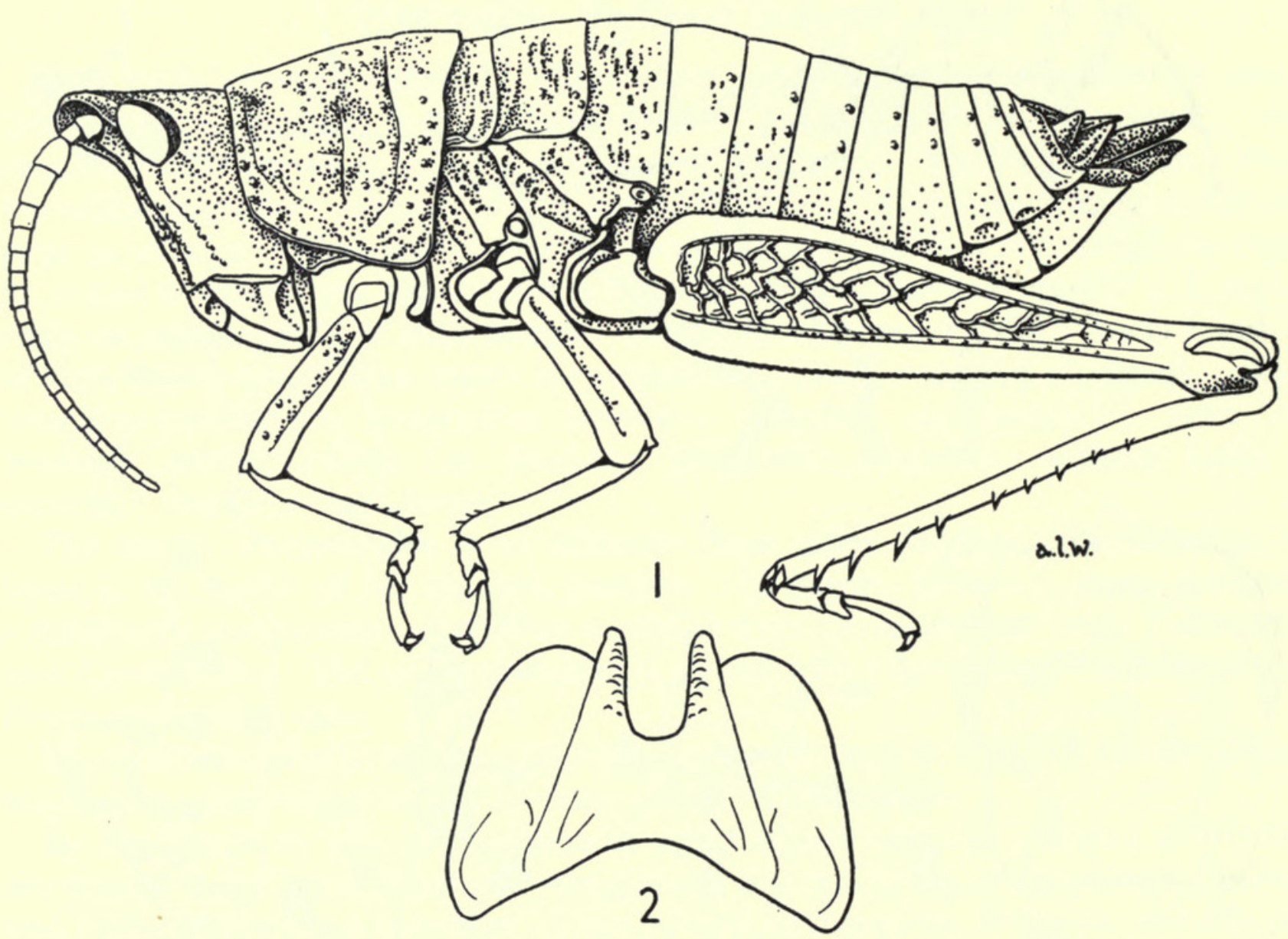

FIG. 6. Xyronotus aztecus I. Bol. I. Whole insect, female. 2. Epiphallus.

it as a tribe ". . . temporarily attached to the Trigonopterygidae". It was raised to family rank by Dirsh (I955).

As can be seen from the diagnosis, there are several characters, like the presence of the fastigial furrow and the shape of the hind femur, which Xyronotus shares with other families, but the stridulatory mechanism is extremely peculiar, similar to that in Pneumoridae and Tanaoceridae, to which Xyronotidae are not otherwise related. The mechanism and the primitive phallic complex do not permit Xyronotus to be placed into any known family and there is no alternative to regarding it as the only known genus of a distinct family.

The only genus, Xyronotus I. Bolivar, I884, occurs in Mexico. 


\title{
Family Trigonopterygidae
}

\author{
(Text-fig. 7) \\ Type genus: Trigonopteryx Charpentier, I84I
}

Body strongly laterally compressed. Head conical. Fastigial furrow present. Prosternal process present. Elytra widening towards apex, with radial and medial veins fused. Remigium of hind wings almost as wide as vannus. Tympanum absent. Lower basal lobe of hind femur shorter than upper one. Brunner's organ present. External spine of hind tibia present. Phallic complex in reversed position, dorsal side turned ventrad, with penis directed towards anterior end of body and epiphallus located on ventral side. Ectophallus differentiated and strongly specialized ; cingulum well developed; valves of penis paired, divided. Epiphallus platelike. Oval sclerites absent. No stridulatory mechanism known.

Westwood (I84I), who described the genus Systella, placed it " between Truxalides and Conophori". Walker (I870) regarded the two known genera as a family which he named Trigonopterygidae, but I. Bolivar (I884) placed it in Pyrgomorphinae as a subtribe and in I909 referred it to Pyrgomorphinae as "sectio Systellae". Dirsh (I952) restored the group as a subfamily Trigonopteryginae and in I956, owing to the peculiar structure of the phallic complex, re-instated it as a family.

The very peculiar, strongly specialized and reversed phallic complex is alone sufficient to separate Trigonopterygidae from the other families. The unusual shape of the elytron and wings, the elytron widening towards the apex, with the radius and media fused, and the wide remigium of the hind wing, do not occur in other families except Pneumoridae. The combination of a distinct fastigial furrow and the lower basal lobe of the hind femur being shorter than the upper one, occurs only in Trigonopterygidae and Xyronotidae, but the latter are extremely different in all other respects. All diagnostic features indicate that the family is isolated from the others.

The family is found in Malaya, Australasian Archipelago and Philippines.

\section{List of examined genera :}

I. Systella Westwood, I84I

2. Trigonopteryx Charpentier, $\mathrm{I} 84 \mathrm{I}$

\section{Family Charilaidae}

(Text-fig. 8)

\section{Type genus : Charilaus Stål, I875}

Body subcylindrical. Head conical. Fastigial furrow present. Pronotum with two parallel median carinae. Prosternal process present. Mesosternal furcal suture curved backwards. Elytra and wings fully developed or reduced. In fully winged forms, wing-elytron stridulatory mechanism present. Tympanum present. Lower basal lobe of hind femur longer than or equal to upper one. Brunner's organ present. External apical spine of hind tibia present. Ectophallus differentiated; 

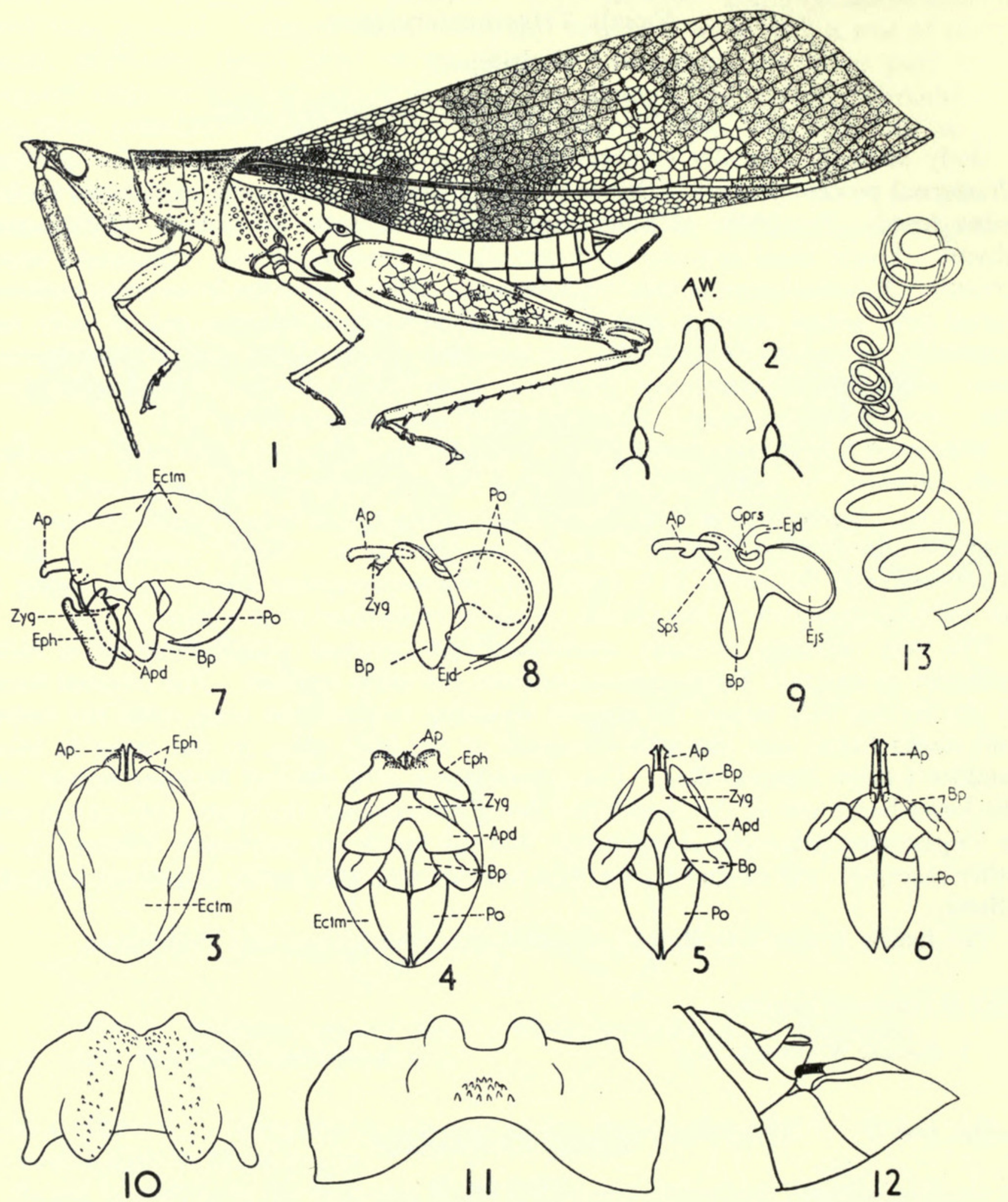

FIG. 7. Trigonopteryx hopei Westw. I. Whole insect, male. 2. Fastigium of vertex from above. 3-ro. Phallic complex. 3. Dorsal view. 4. The same, ventral view. 5. Ventral view, but ectophallic membrane and epiphallus removed. 6. The same, with cingulum removed. 7. Whole phallic complex, in profile. 8. The same, with ectophallic membrane and epiphallus removed. 9. Endophallus, in profile. Io. Epiphallus. II. Epiphallus of Systella rafflesii Westw. I2. End of abdomen of Trigonopteryx hopei Westw. in profile, showing the position of penis. I3. Spermatheca of Systella rafflesii Westw. 


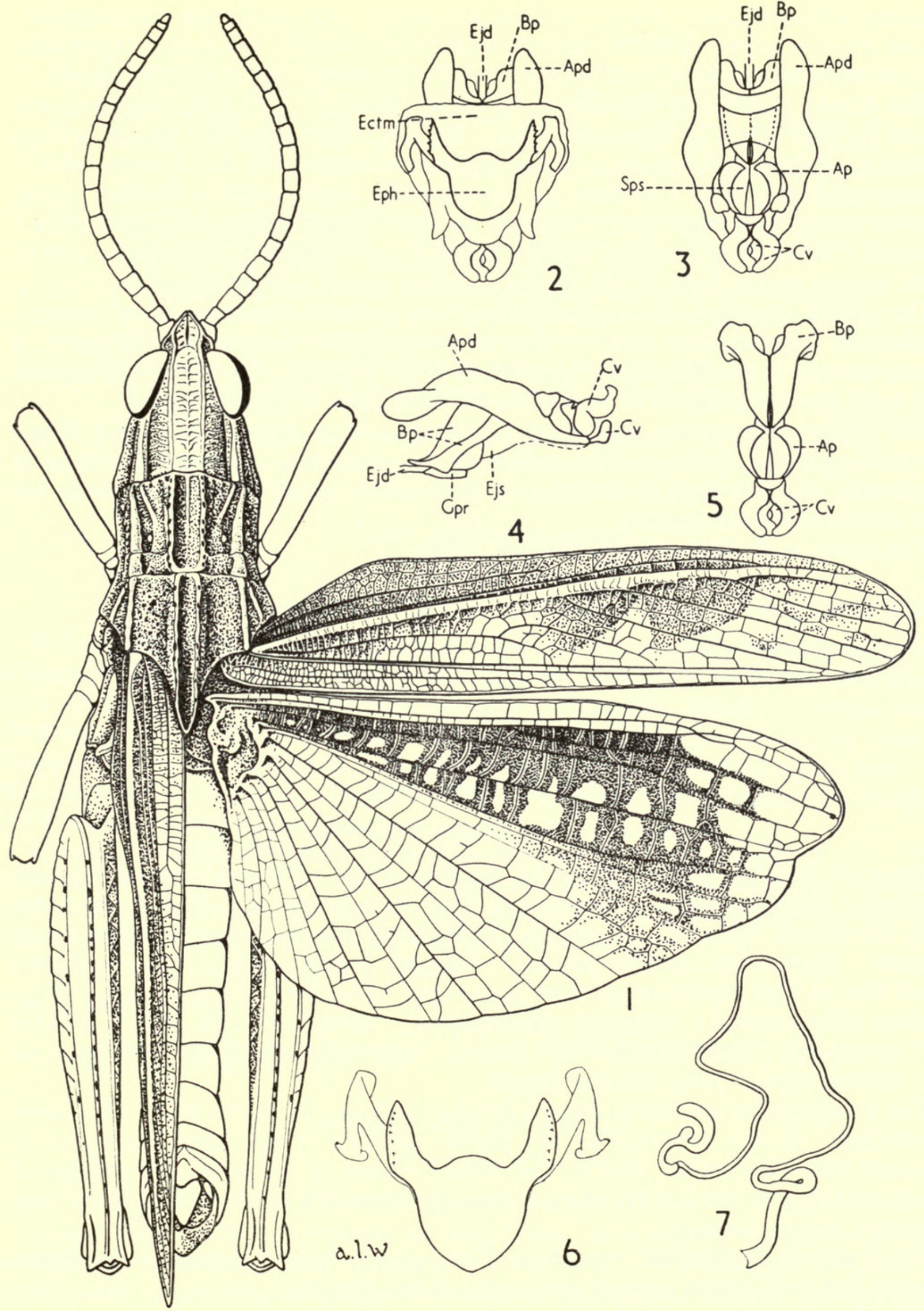

Fig. 8. Charilaus carinatus St. I. Whole insect, male. 2-6. Phallic complex. 2. Whole phallic complex from above. 3. The same, but ectophallic membrane and epiphallus removed. 4. The same, in profile. 5. Endophallus from above. 6. Epiphallus. 7. Spermatheca. 
cingulum differentiated, without zygoma and rami ; with apodemes disconnected ; valves of penis paired, divided ; spermatophore sac dorsal. Epiphallus shield-like, without ancorae and lophi, with ventro-lateral appendices. Oval sclerites absent.

The family Charilaidae includes three known genera. The first, Charilaus, was placed by Stål (1875) in Pyrgomorphidae. Karsch (I896) suggested that it belongs neither to Pyrgomorphidae nor to Pamphagidae and referred it to "Caloptenoden". Saussure (I889) placed Charilaus in Pamphagidae, and so did I. Bolivar (I9I6). Uvarov (I943) suggested that it belongs to the "Pamphaginae-Pyrgomorphinae" complex. Dirsh (I953) erected for the group a new subfamily Charilainae and in I956, mainly on the basis of the phallic complex, raised it to family rank.

The phallic complex of Charilaidae has very little in common with Pyrgomorphidae and approximates more to that in Pamphagidae, from which, however, it differs strongly in the disconnected apodemes of the cingulum, the absence of zygoma and rami, and the presence of ventro-lateral appendices of the epiphallus.

The external characters separating Charilaidae from Pamphagidae and Pyrgomorphidae are the double median carina of the pronotum, a character unique in Acridoidea, and the type of stridulatory mechanism, which does not occur in the two above-mentioned families.

The family is distributed in S. and SW. Africa.

\section{List of known genera :}

I. Charilaus Stål, I875

2. Hemicharilaus Dirsh, 1953

3. Pamphagodes I. Bolivar 1878

\section{Family Pamphagidae}

\section{Type genus: Pamphagus Thunberg, I8I5}

Body of variable shape. Head of variable shape. Fastigial furrow present. Prosternal process present. Mesosternal furcal suture straight. Elytra and wings fully developed, reduced, or absent. Stridulatory mechanism of various types present. Tympanum usually present. Krauss's organ mostly present. Lower basal lobe of hind femur longer than upper one. Brunner's organ present. Ectophallus differentiated; cingulum differentiated; valves of penis paired, divided and articulated; spermatophore sac dorsal. Epiphallus shield-like, with ancorae and without lophi. Oval sclerites absent.

The Pamphagidae are a well defined family which has no clear affinity with other Acridoidea. In the structure of the phallic complex it has some characters in common with Charilaidae, such as the divided valves of the penis, the position of the spermatophore sac and the shape of the epiphallus, but other characters are very different (see Charilaidae).

The family is distributed throughout Africa and S. Europe and occurs in mountainous and semi-desert parts of Asia as far as the Far East.

The Pamphagidae are divided here into four subfamilies. 


\section{Key to Subfamilies of Pamphagidae}

I (6) Middle tibia without teeth or tubercles on upper side. If winged, second vannal vein of hind wing not curved and no areas of hind wing expanded

2 (3) Body strongly elongated, comparatively slender, cylindrical. Fastigium of vertex and upper part of frons, strongly projecting forwards. Antenna triangular in cross-section. Epiphallus mostly with deeply excised posterior margin. Krauss's organ absent . . . . . . Echinotropinae

3 (2) Body stout, compressed or depressed. Fastigium of vertex moderately or not at all projecting forwards. Antenna of variable shape. Posterior margin of epiphallus not excised. Krauss's organ mostly present.

4 (5) Costal area of elytron (in case of fully developed or shortened elytra) expanded and covered with dense, parallel, ridge-like veinlets (stridulatory specialization). Upper carina of hind femur strongly serrated

Porthetinae

5 (4) Elytra never fully developed, lobiform, lateral, without stridulatory specialization. Upper carina of hind femur smooth, slightly serrated or rarely strongly serrated.. . . . . . . . Pamphagi

6 (I) Middle tibia on upper side with a row of teeth or tubercles. If winged, second vannal vein of hind wing curved and first and third vannal area expanded

Akicerinae

\section{Subfam. Echinotropinae}

(Text-fig. 9)

Type genus : Echinotropis Uvarov, I944

Body strongly elongated, cylindrical. Integument strongly rugose. Antenna triangular in cross-section, tapering towards apex. Fastigium of vertex and upper part of frons strongly protruding forwards. Pronotum spined or tuberculate. Prosternal process low, collar-like. Elytra fully developed, lobiform, or absent. Tympanum present or absent. Krauss's organ absent. External apical spine of hind tibia present or absent. Epiphallus mostly with deeply excised posterior margin. No stridulatory mechanism known.

The genera of this subfamily represent a natural and a very peculiar group. The most distinctive features are elongate, slender body, which is unusual for Pamphagidae, complete absence of Krauss's organ and a characteristic epiphallus, with the posterior end deeply excised in the middle (in two genera).

The subfamily occurs only in S. Africa.

\section{List of known genera :}

I. Echinotropis Uvarov, 1944

2. Geloiomimus Saussure I 899

3. Thrincotropis Saussure, I 899

\section{Subfamily Porthetinae nov.}

\section{(Text-fig. Io)}

\section{Type genus : Porthetis Serville, I83I}

Large, with body compressed or depressed. Integument rugose. Antenna compressed, differentiated or tapering towards apex, or ribbon-like. Frons, in profile, with protruding fastigium of vertex or straight. Pronotum from highly crested to flat, depressed. Prosternal process of variable shape. In most cases 

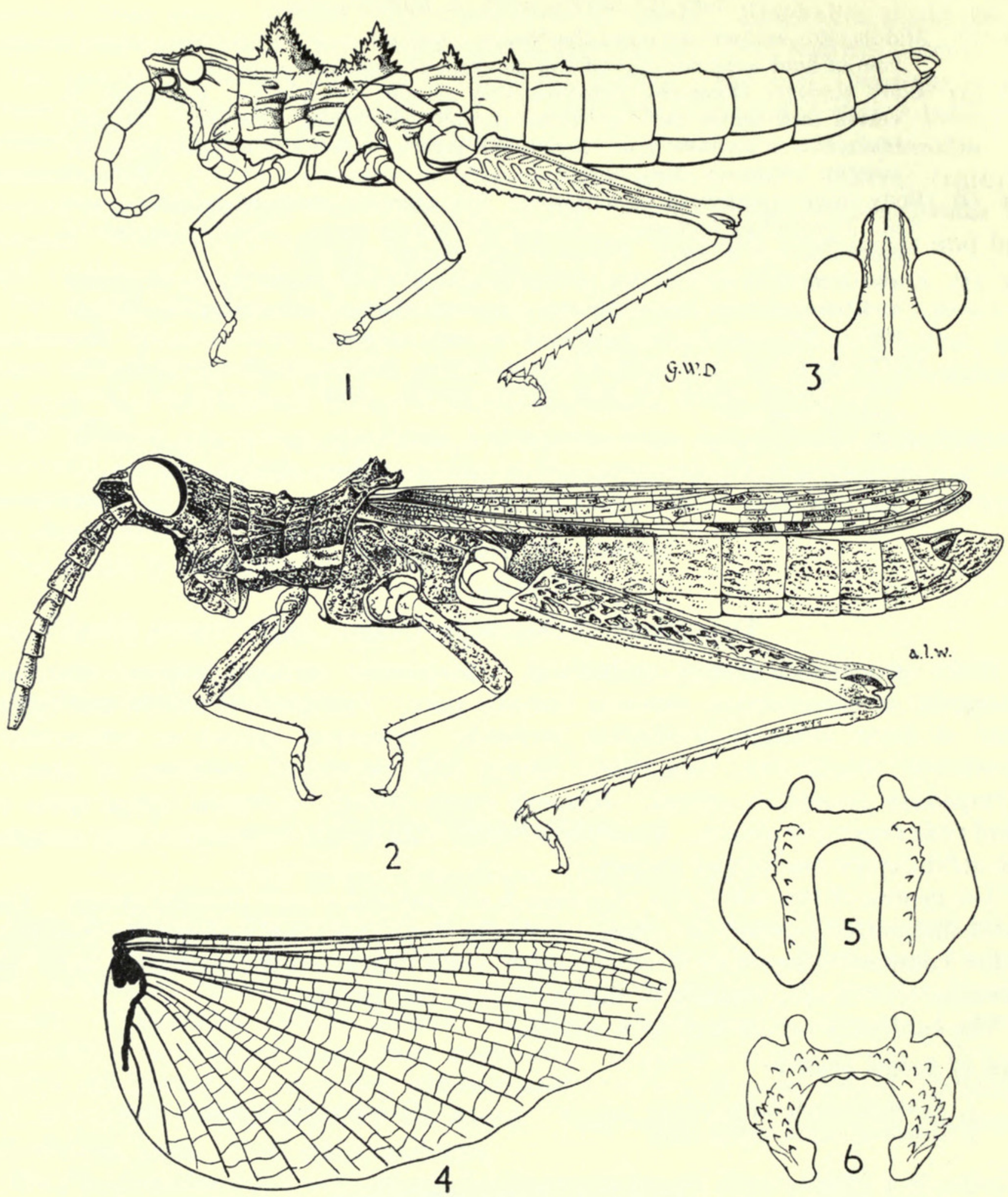

FIG. 9. I. Echinotropis horrida (Sauss.), female. 2-5. Geloiomimus spinosus (Dirsh), 2. male. 3. Head from above. 4. Wing. 5. Epiphallus. 6. Epiphallus of Geloiomimus nasicus Sauss. 
males winged, females wingless. Costal area of elytron (except Bolivarella with small lobiform elytra) expanded and provided with dense, parallel, ridge-like stridulatory veinlets. Krauss's organ present. Tympanum present, open, without subtympanal
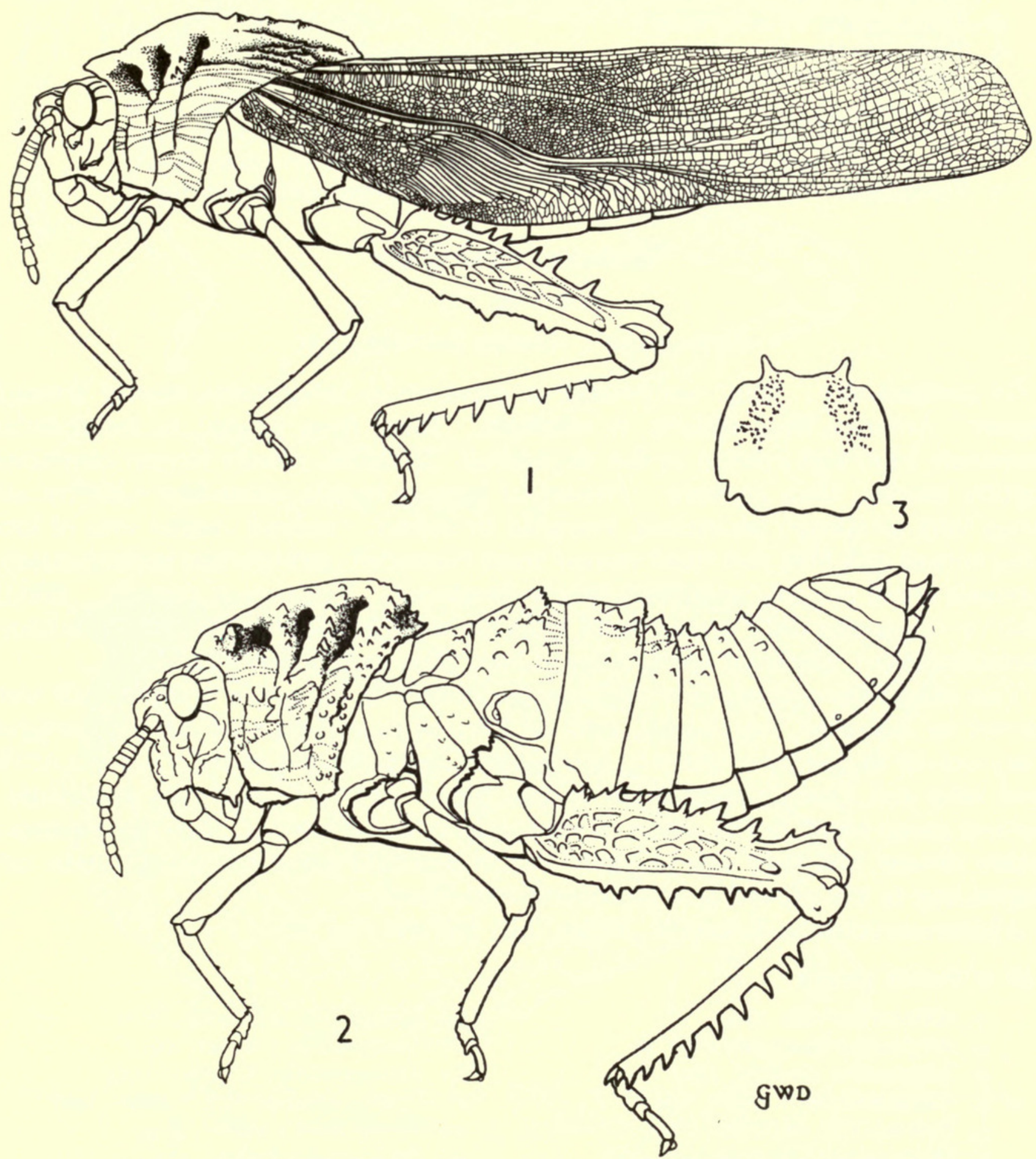

FIG. Io. Porthetis carinata (L.). I. Male. 2. Female. 3. Epiphallus.

lobe. External apical spine of hind tibia present. Apical valves of penis mostly serrated.

The Porthetinae were regarded as a group (Dirsh, I958), but according to all the characters and particularly owing to the peculiar stridulatory mechanism, it deserves to be accorded subfamily rank. 
This subfamily is distributed from S. Africa to Angola, E. Africa, the Red Sea area and the SW. corner of Arabia.

\section{List of known genera :}

I. Aphantotropis Uvarov, I924

2. Bolivarella Saussure, 1887

3. Cultrinotus I. Bolivar, 1925

4. Hoplolopha Stål, I876

5. Lamarckiana Kirby, I910

6. Lobosceliana Dirsh, 1958

7. Pagopedilum Karsch, 1896
8. Porthetis Serville, I83I
9. Puncticornia Dirsh 1958
Io. Stolliana I. Bolivar, I916
II. Trachypetrella Kirby, I910
12. Transvaaliana Dirsh, 1958
13. Vansoniacris Dirsh, $195^{8}$
14. Xiphoceriana Dirsh, $195^{8}$

\section{Subfamily Akicerinae}

(Text-fig. II)

\section{Type genus : Akicera Serville, I83I}

Of medium size; body compressed or depressed. Integument mostly strongly rugose. Antenna from filiform to ensiform. Head from conical to subglobular. Pronotum from high crested to flat, depressed ; metazona mostly longer, sometimes slightly shorter, than prozona. Prosternal process mostly collar-like. Elytra and wings fully developed, shortened, vestigial, or absent. Second vannal vein of hind wing curved and first and third vannal areas expanded (stridulatory specialization). Krauss's organ present, sometimes poorly developed. Tympanum present. Middle tibia on upper side with row of small teeth or tubercles (second part of stridulatory specialization). External apical spine of hind tibia mostly present.

This subfamily represents a combination of several groups or tribes which were known as Akicerini, Adephagini, part of Thrinchini and part of Batrachotetrigini. They are all united by a common stridulatory specialization of the venation of the hind wing and specialization of the middle tibia. In this respect they constitute a natural group equal to the others of subfamily rank. However, their appearance is rather diverse and they can be easily subdivided into lower taxonomic units, corresponding to the groups or tribes mentioned above.

Akicerinae occur in S. and N. Africa, SE. Europe and Asia.

\section{List of known genera:}

I. Akicera Serville, I83I

2. Adephagus Saussure, 1887

3. Asiotmethis Uvarov, 1943

4. Atrichotmethis Uvarov, 1943

5. Batrachornis Saussure, I 884

6. Batrachotetrix Burmeister, 1838

7. Eotmethis Bey-Bienko, 1948

8. Eremocharis Saussure, I884

9. Eremopeza Saussure, 1884

I0. Evemotettix Saussure, 1888

II. Evemotmethis Uvarov, I943

12. Filchnerella Karny, 1908

13. Glyphanus Fieber, 1853

14. Glyphotmethis Bey-Bienko, 1948
I5. Haplotropis Saussure, $\mathrm{I} 888$

I6. Ivanotmethis Uvarov, 1943

I7. Melanotmethis Uvarov, I943

I8. Mongolotmethis Bey-Bienko, 1948

19. Pezotmethis Uvarov, 1943

20. Prionotropis Fieber, 1853

21. Pseudotmethis Bey-Bienko, I948

22. Rhinotmethis Sjöstedt, $\mathbf{1 9 3 3}$

23. Strumiger Zubowsky, 1896

24. Thrinchus Fischer v. Waldheim, I833

25. Tmethis Fieber, I 853

26. Tuarega Uvarov, 1943

27. Utubius Uvarov, 1936 


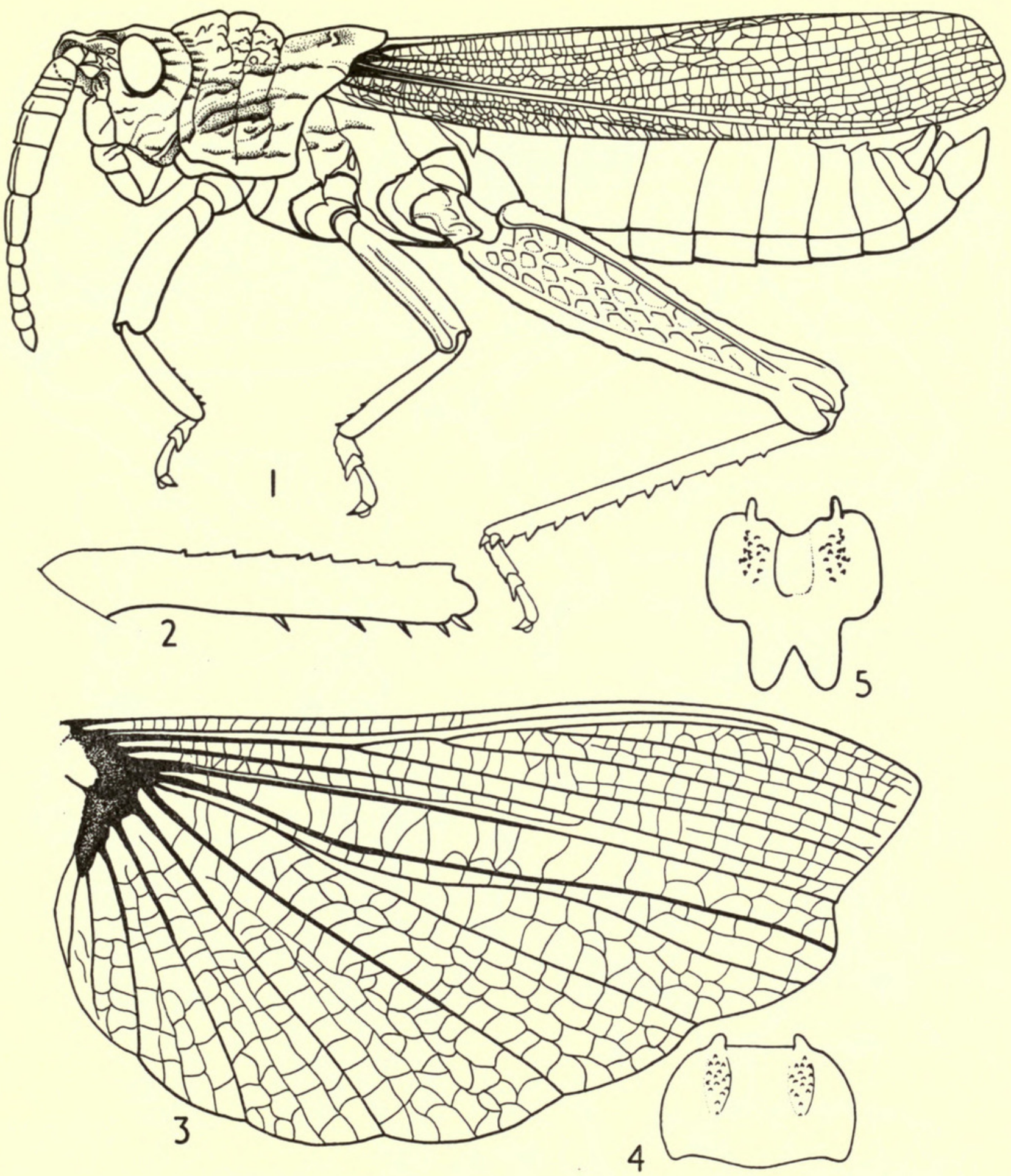

FIg. II. I-4. Akicera fusca (Thunb.). I. Male. 2. Middle tibia, with dorsal serration. 3. Wing. 4. Epiphallus. 5. Epiphallus of Tmethis cisti (F.)

\section{Subfamily Pamphaginae}

(Text-fig. I2)

Type genus : Pamphagus Thunberg, I8I5

From small to large size; body compressed to depressed. Integument rugose, sometimes shiny. Antenna filiform, ribbon-like or weakly ensiform. Fastigium of 


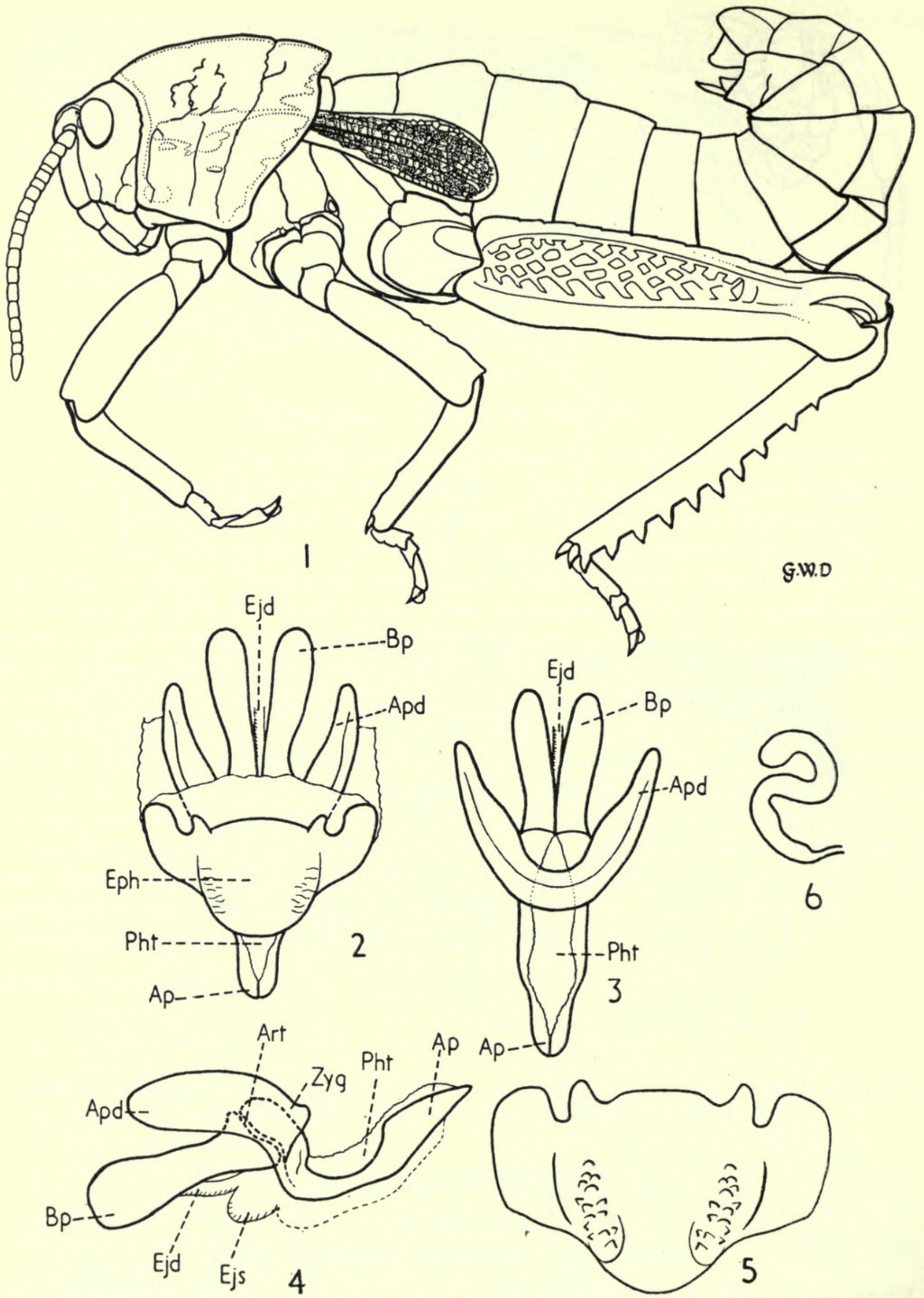

FIg. I2. Pamphagus elephas (L.). I. Male. 2-5. Phallic complex. 2. Whole phallic complex from above. 3. The same, but ectophallic membrane and epiphallus removed. 4. The same in profile. 5. Epiphallus. 6. Spermatheca. 


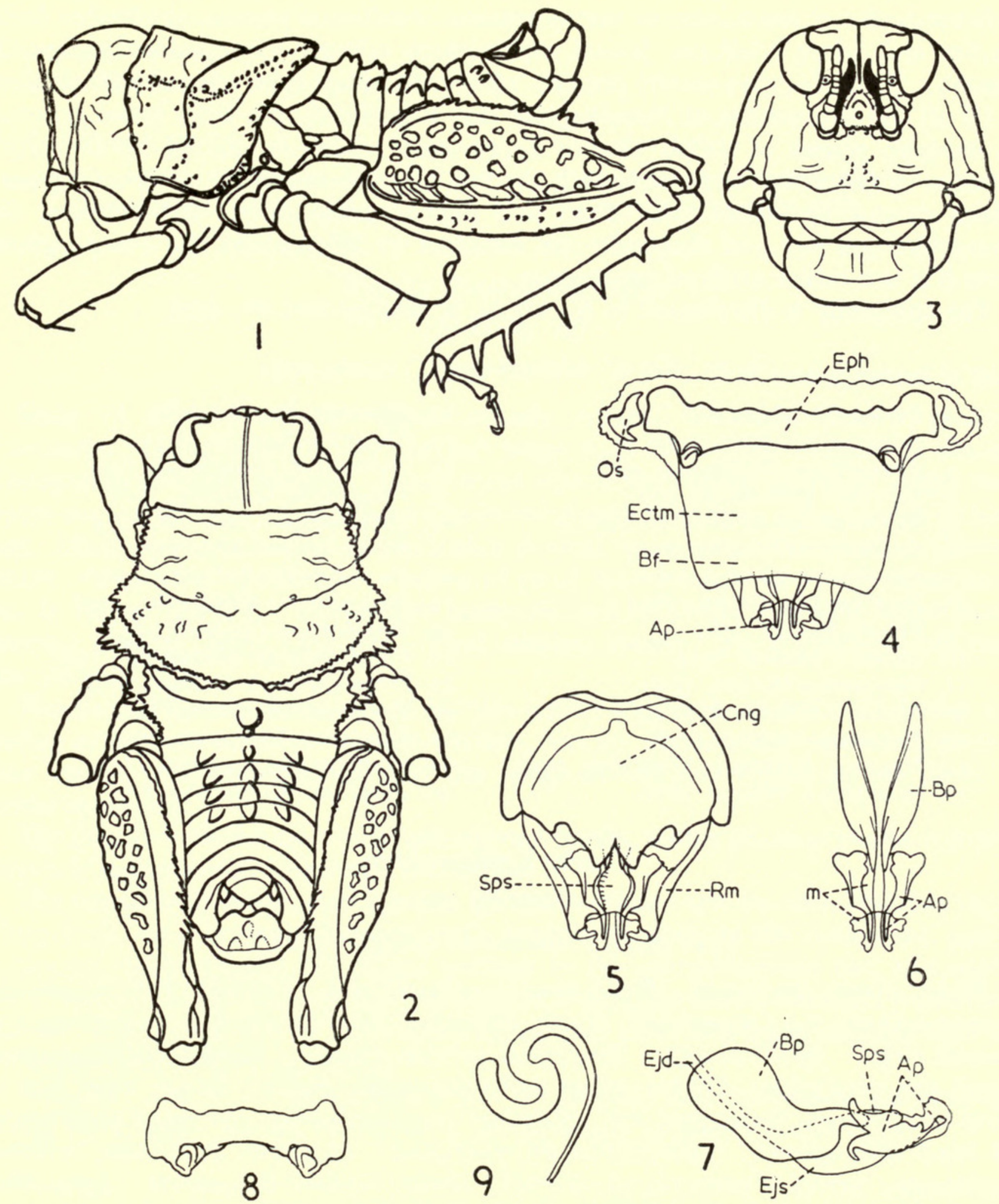

FIG. I3. I-3 Batrachidacris tuberculata (Rehn). I. Male, in profile. 2. The same, from above. 3. Face (antennal grooves painted black). 4-7. Phallic complex of Batrachidacris rubridens (Uv.). 4. Whole phallic complex from above. 5. The same, but ectophallic membrane and epiphallus removed. 6. Penis, from above. 7. Endophallus, in profile. 8. Epiphallus of Batrachidacris tuberculata (Rehn). 9. Spermatheca of Lathicerus cimex Sauss. 
vertex slightly projecting forwards. Pronotum from crest-like to flat, depressed; metazona always much shorter than prozona. Prosternal process of variable form. Elytra and wings lobiform, lateral, vestigial or absent. Tympanum present or absent. Krauss's organ mostly present. External apical spine of hind tibia present.

Of all the subfamilies of Pamphagidae this is probably the most heterogeneous. It contains genera of widely diverse appearance, which are united by the retrogression of characters connected with the loss or great reduction of wings ; genera which cannot be placed into other, well defined subfamilies. Nevertheless, the characters (see key and diagnosis) are sufficient to differentiate the Pamphaginae, even if it is a rather artificial assemblage.

The subfamily is distributed in N. Africa, S. Europe and W. Asia.

\section{List of known genera:}

I. Acinipe Rambur, 1838

2. Acrostiva Enderlein, I929

3. Ananothrotes Mistshenko, I95I

4. Araxiana Mistshenko, I95I

5. Bufonocarodes Mistshenko, I95I

6. Eunapiodes I. Bolivar, I907

7. Eunothrotes Adelung, 1907

8. Euryparyphes Fischer, 1853

9. Finotia Bonnet, I884

ı. Glania I. Bolivar, I9I2

II. Glauvarovia Morales, I949

I2. Iranacris Mistshenko, 195 I

I3. Nocaracris Uvarov, 1928

I4. Nocarodes Fischer v. Waldheim, I 846

I5. Ocneridia I. Bolivar, I9I 2
I6. Ocnerodes Brunner, I882

I7. Ocneropsis Uvarov, 1942

I8. Oronothrotes Mistshenko, I95I

I9. Pamphagus Thunberg, I8I5

20. Paraeumigus I. Bolivar, I9I4

2I. Paranocaracris Mistshenko, I95I

22. Paranocarodes I. Bolivar, I9I6

23. Paranothrotes Mistshenko, I95I

24. Pseudamigus Chopard, I943

25. Pseudonothrotes Mistshenko, I95I

26. Prionosthenus I. Bolivar, 1878

27. Purpuraria Enderlein, 1929

28. Savalania Mistshenko, I95I

29. Tropidauchen Saussure, 1887

3o. Znojkiana Mistshenko, I95I

\section{Family Lathiceridae}

(Text-fig. I3)

\section{Type genus : Lathicerus Saussure, I888}

Body robust, depressed. Head mostly prognathous. Fastigial furrow present. Antenna short, 7-I3 segmented, closely fitted into deep antennal groove on sides of frontal ridge. Ocelli absent. Prosternal process present. Metasternal interspace short and very wide. Elytra, wings and tympanum absent. Lower basal lobe of hind femur longer than upper one. Brunner's organ present. External apical spine of hind tibia absent. Ectophallus differentiated; cingulum shield-like, without apodemes ; valves of penis paired, divided ; spermatophore sac ventral. Epiphallus bridge-shaped, with lophi and without ancorae. Oval sclerites present. Stridulatory mechanism not known.

The first two genera of the family, Lathicerus and Crypsicerus, when described by Saussure in I888, were placed by him in "Thrincites" of Oedipodinae. In I943 Uvarov transferred the three then known genera of the group to the tribe Thrinchini of Pamphagidae. Dirsh, after study of the phallic complex, raised the group to subfamily rank (I954) and later (I956) to family rank. 
REVISION OF THE FAMILIES AND SUBFAMILIES OF ACRIDOIDEA $38 \mathrm{I}$

The reasons for regarding this group as a family are obvious from the diagnosis. Such a striking character as the antennal grooves is not known in other families. The cingulum and penis are also quite unique.

Lathiceridae occur in S. and SW. Africa only.

\section{List of known genera :}

I. Batrachidacris Uvarov, 1939

2. Crypsiceracris Miller, I932

3. Crypsicerus Saussure, I 888

4. Lathicerus Saussure, I 888

\section{Family Pyrgomorphidae}

(Text-fig. I4)

\section{Type genus : Pyrgomorpha Serville, I 838}

Body of variable shape. Head acutely conical. Fastigial furrow present. Prosternal process present. Elytra and wings fully developed, reduced or absent. Tympanum normally present. Lower basal lobe of hind femur normally longer than upper one. Brunner's organ present except few genera, with thin, almost cursorial hind legs. External apical spine of hind tibia present or absent. Ectophallus differentiated ; cingulum capsule-like ; valves of penis paired, undivided ; spermatophore sac in dorsal position. Epiphallus bridge-shaped, with dorso-lateral appendices; ancorae absent ; lophi hook-like. Oval sclerites absent. No stridulatory mechanism known.

The name Phymateidae was used for this family by Jakobson \& Bianki (I904) and earlier as a group name by various authors, but for the last fifty years and more it was known as Pyrgomorphidae and this usage should be retained as less likely to cause confusion.

The Pyrgomorphidae are a very well defined family, with a peculiar phallic complex which is rather uniform through the family.

The relationship with other families is rather obscure and no close affinities exist. They have some common features with Lentulidae, such as the undivided, paired valves of the penis and the dorsal position of the spermatophore sac, and others with Ommexechidae, such as the presence of a fastigial furrow and the paired undivided valves of the penis. All other characters, however, are so distinct that the relationship is a very remote one.

Pyrgomorphidae are represented in all the tropical and subtropical parts of the world by a large number of genera, a list of which appears unnecessary.

\section{Family Ommexechidae}

(Text-fig. I5)

Type genus: Ommexecha Serville, I83I

Body of variable shape. Head of variable shape. Fastigial furrow present. Prosternal process present. Elytra and wings fully developed, shortened or absent. Cubital vein of elytron unbranched. Tympanum present or absent. Stridulatory 


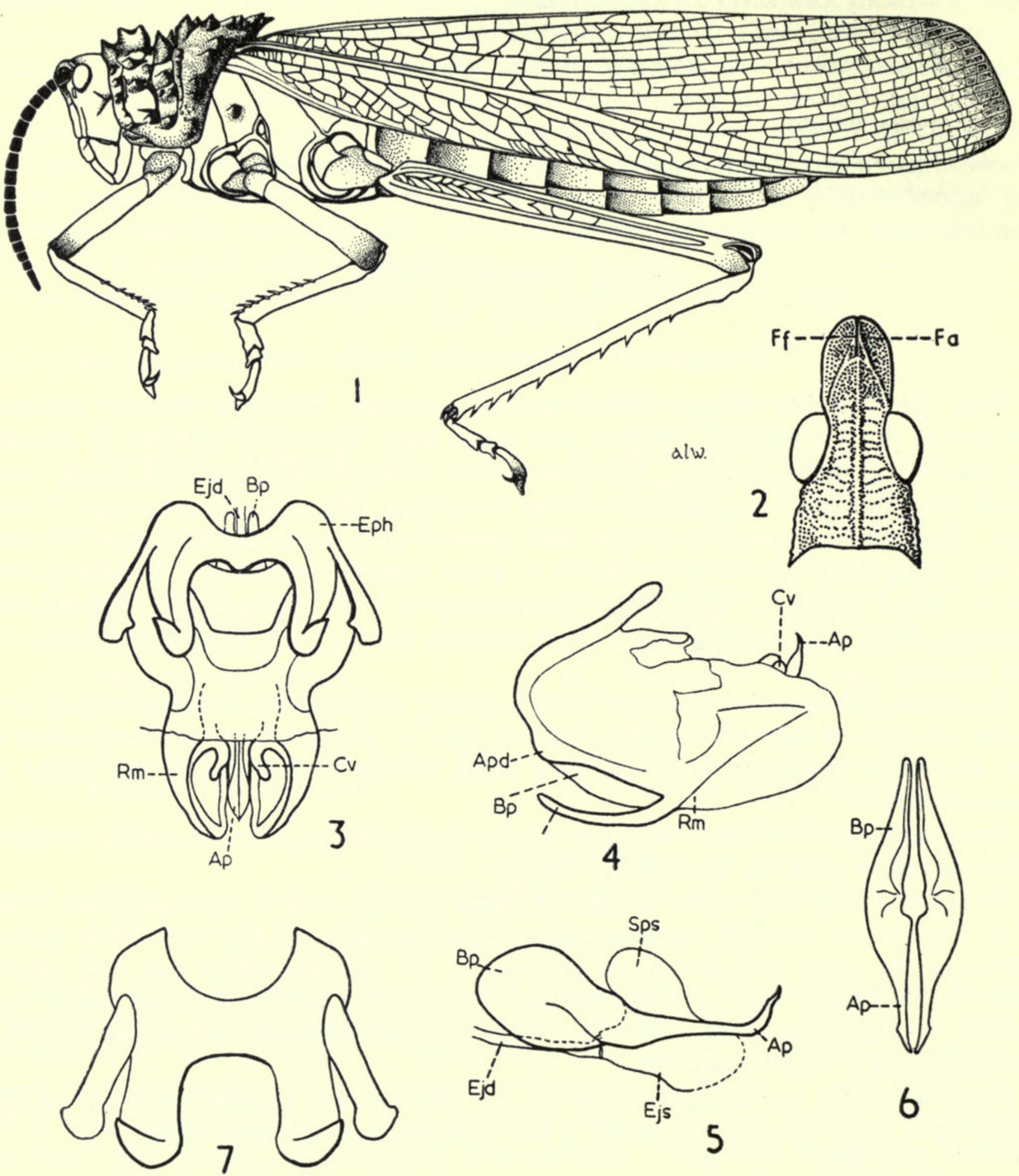

FIg. I4. I. Phymateus viridipes St., male. 2. Head of Pyrgomorphella arachidis Dirsh (Ff. fastigial furrow. Fa. fastigial area). 3-6. Phallic complex of Phymateus morbillosus (L.). 3. Whole phallic complex from above. 4. The same, in profile. 5. Endophallus, in profile. 6. Penis, from above. 7. Epiphallus of Phymateus purpurascens Karsch. 

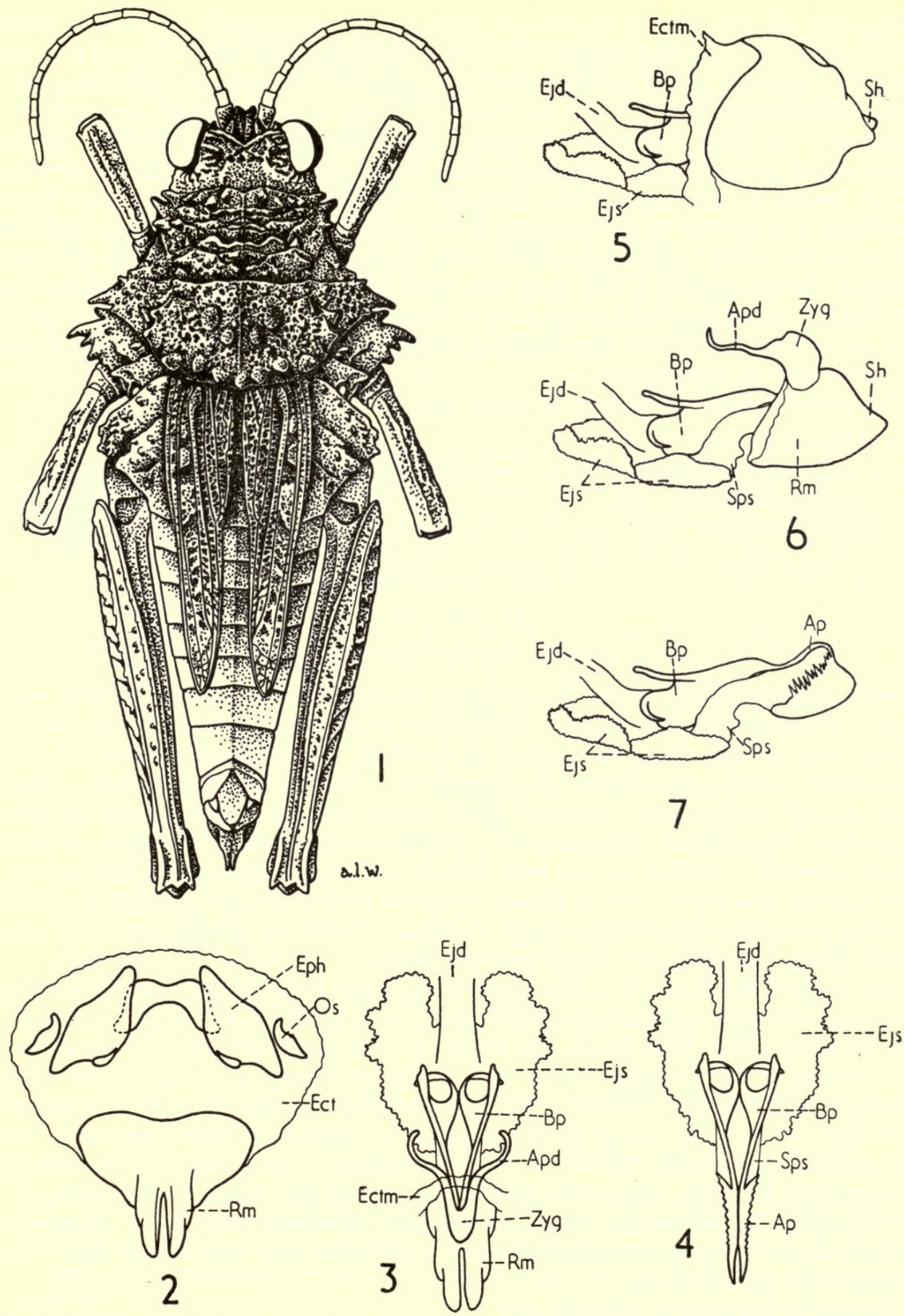

FIG. I5. I-7. Ommexecha servillei Blanch. I. Female. 2-7 Phallic complex. 2. Whole phallic complex from above. 3. The same, but ectophallic membrane and epiphallus removed. 4. Endophallus from above. 5. In profile. 6. The same, with ectophallic membrane removed. 7. Endophallus in profile. 
mechanism (elytron-femur) sometimes present, but very imperfect. Lower basal lobe of hind femur as long as, or slightly longer than, upper one. Brunner's organ present. External apical spine of hind tibia absent. Ectophallus differentiated; cingulum differentiated, forming apodemes; valves of penis paired, not divided; ejaculatory sac with additional pockets. Epiphallus bridge-shaped, with lateral plates joined by membrane ; ancorae absent ; lophi present. Oval sclerites present.

This family is very insufficiently studied. Very remote affinity with the Pyrgomorphidae is suggested by the presence of the fastigial furrow and by the undivided valves of the penis; the latter, which were described (Dirsh, I956) as flexured owing to the presence of a very long and thick flexure, may be better regarded as not divided, but rather as having a very elongate and rather thin medial part. The peculiar joining of the lateral plates of the epiphallus by membrane is found elsewhere only in Pauliniidae.

The Ommexechidae occur in S. America only.

List of known genera :

I. Graea Philippi, I863

2. Ommexecha Serville, I83I

3. Pachyossa Rehn, I9I3

4. Parossa Bruner, I9II

5. Spathalium I. Bolivar, I884

\section{Family Pauliniidae}

(Text-fig. I6)

Type genus: Paulinia Blanchard, I843

Body subcylindrical. Head subconical. Fastigial furrow absent. Ocelli very large. Prosternal process absent. Elytra and wings fully developed or shortened. Medial and cubital veins of elytron unbranched. Tympanum present. Lower basal lobe of hind femur shorter than upper one. Brunner's organ present. Hind tibia strongly expanded; external apical spine present; basal tarsal segment expanded. Ectophallus differentiated; cingulum differentiated; valves of penis paired, divided; ejaculatory sac with lateral pockets. Epiphallus bridge-shaped, with ancorae and lophi ; lateral plates connected with bridge by membrane. Oval sclerites present. Ovipositor strongly reduced, shorter or hardly exceeding subgenital plate. Stridulatory mechanism not found.

The family Pauliniidae is insufficiently studied and its position is rather doubtful. The structure of the epiphallus and ejaculatory sac approximate it to Ommexechidae, but the lobes of the hind femur, the lower lobe being shorter than the upper, and the absence of the fastigial furrow and of the prosternal process, suggest some affinity with Acrididae. However, the whole phallic complex, with its complicated structure, the divided valves of the penis, the complicated ejaculatory sac, and the peculiar epiphallus, isolate it from Acrididae. According to the size of chromosomes (Helwig, I958), the Pauliniidae cannot be placed in Acrididae.

The family at present contains two genera: Paulinia Blanchard, I843, and Marellia Uvarov, I929, but the latter genus probably does not belong here. Its affinity needs further study.

The family occurs in S. America only. 

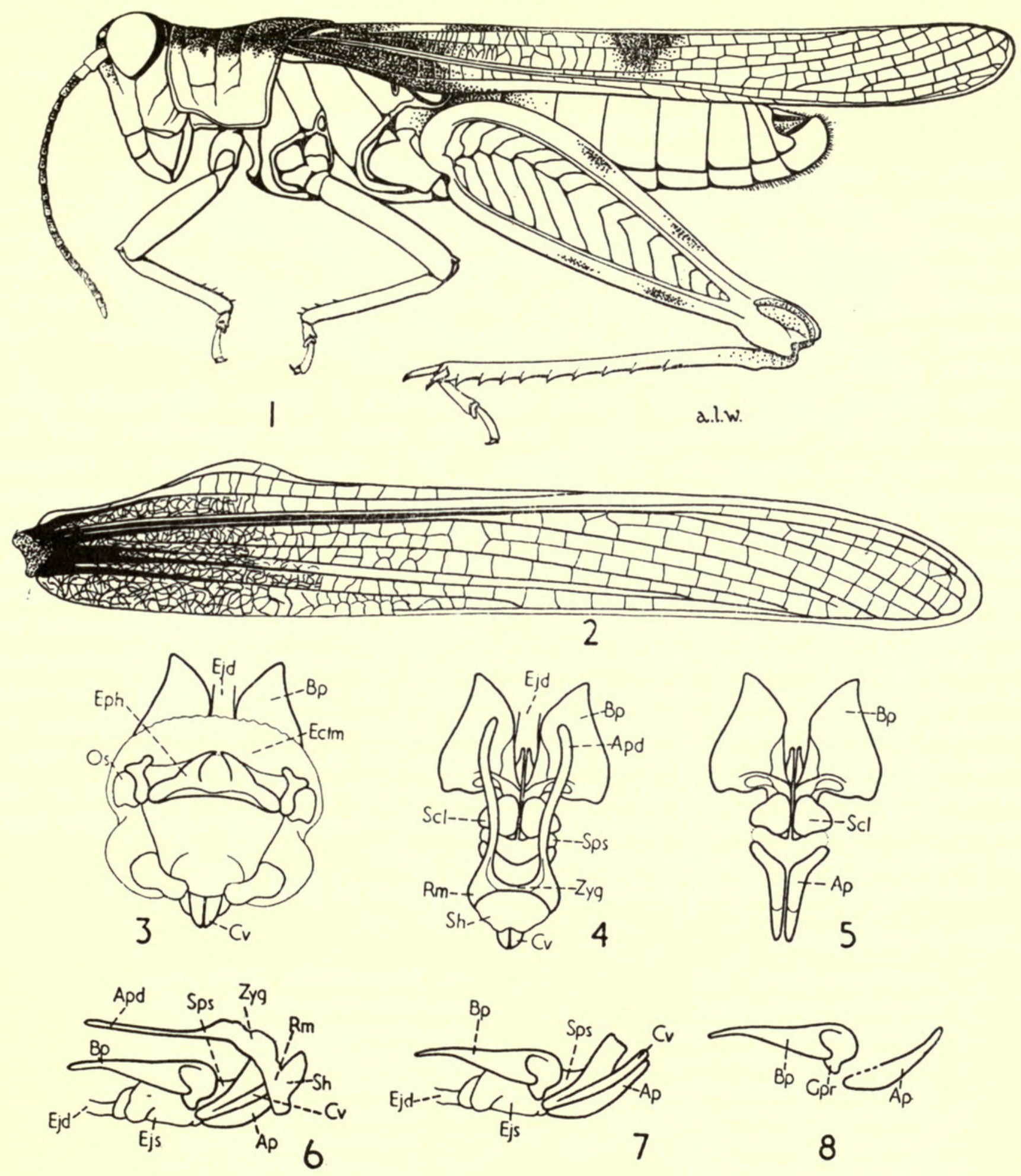

8

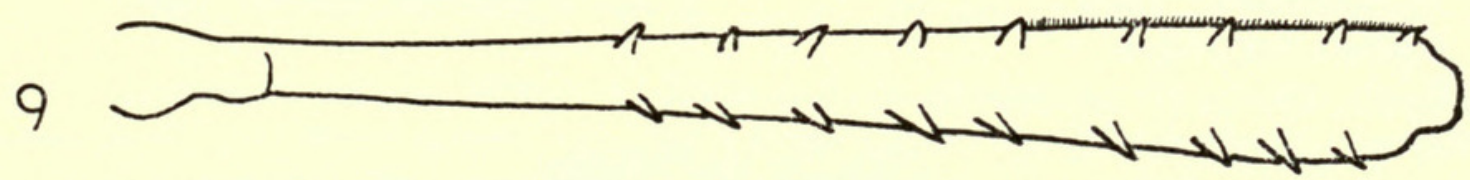

FIG. I6. I-8. Paulinia acuminata (DeGeer). I. Male. 2. Right elytron. 3-8. Phallic complex. 3. Whole phallic complex from above. 4. The same, but ectophallic membrane and epiphallus removed. 5. Endophallus, from above. 6. As 4 , but in profile. 7. Endophallus, in profile. 8. Penis, in profile. 9. Left hind tibia from above. 


\section{Family Lentulidae}

(Text-fig. I7)

\section{Type genus : Lentula Stål, I878}

Body of variable shape. Head of variable shape. Fastigial furrow absent. Pronotum short. Prosternal process present. Elytra, wings and tympanum absent. Lower basal lobe of hind femur shorter than upper one. Brunner's organ present. External apical spine of hind tibia present or absent. Ectophallus differentiated ; cingulum differentiated ; valves of penis paired, undivided ; spermatophore sac dorsal. Epiphallus bridge-shaped, with ancorae and lophi. Oval sclerites present. Stridulatory mechanisms not found.

This recently erected family (Dirsh, I956) consists of genera with highly retrogressive external characters. They have lost wings and tympanum, and the pro-, meso- and metathorax are reduced. As a result they have a nymphal appearance and are externally similar to the wingless and tympanum-less representatives of other families. The phallic complex, however, provides an excellent character. Its structure is only remotely similar to that of Pyrgomorphidae (Dirsh, I956) and quite different from that in all other families. It is not possible to relate this family closely to any known family. The most difficult problem presented by the Lentulidae is that there are no reliable external characters, and for identification of its representatives it is necessary to investigate the phallic complex. The only external character which is consistent in this family is the complete absence of wings and tympanum, while in the other families this state occurs only as a retrogression. Moreover, in the only species of the family studied with regard to the anatomy, the indirect flight muscles are completely absent in the adult, while they are present in other wingless acridoids (Ewer, I958).

Lentulidae are distributed in South Africa and part of East Africa.

List of known genera :
I. Bacteracris Dirsh, 1956
2. Basutacris Dirsh, I953
3. Betiscoides Sjöstedt, I923
4. Devylderia Sjöstedt, I923
5. Evemidium Karsch, 1896
6. Gymnidium Karsch, 1896
7. Helwigacris Rehn, I944
8. Karruacris Dirsh, 1958
9. Karruia Rehn, 1945
Io. Lentula Stål, I 878

II. Mecostiboides Dirsh, 1957

I2. Mecostibus Karsch, I 896

I3. Nyassacris Ramme, 1929

14. Paralentula Rehn, 1944

I5. Qachasia Dirsh, 1956

I6. Shelfordites Karny, I9ro

I7. Swaziacris Dirsh, 1953

I8. Sygrus I. Bolivar, I889

I9. Usambilla Sjöstedt, I9o9

\section{Family Acrididae}

Type genus : Acrida Linnaeus, I758

Body and head of extremely variable shape. Fastigial furrow absent (rarely present, but apparently as a secondary formation). Prosternal process present or absent. Elytra and wings fully developed or reduced, or absent. Tympanum 
REVISION OF THE FAMILIES AND SUBFAMILIES OF ACRIDOIDEA 387 normally present. Stridulatory mechanisms of various structure found in the majority of subfamilies. Lower basal lobe of hind femur mostly shorter than or equal to upper one. Brunner's organ present. External apical spine of hind tibia
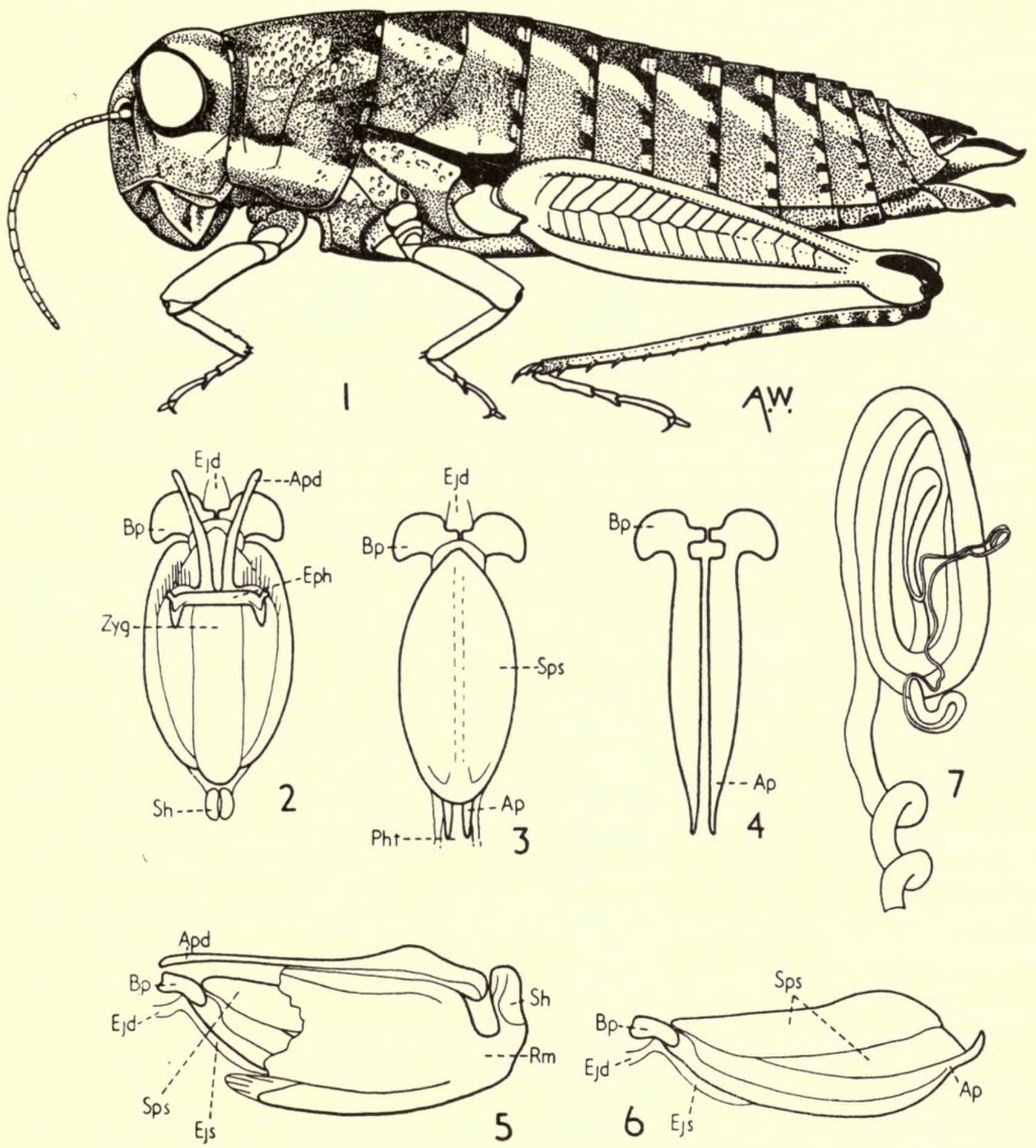

FIG. I7. I-7. Lentula callani Dirsh. I. Male. 2-6. L. obtusifrons St. phallic complex.

2. From above. 3. From below. 4. Penis from above. 5. Whole phallic complex,

in profile. 6. Endophallus, in profile. 7. Spermatheca.

present or absent. Ectophallus differentiated ; cingulum differentiated; valves of penis paired, flexured or divided. Epiphallus mostly bridge-shaped, sometimes disc-shaped, sometimes divided; ancorae and lophi present (sometimes lost). Oval sclerites present. 
The family Acrididae is the most numerous, most heterogeneous and probably most recent and advanced family. It is divided below into seventeen subfamilies of unequal value and probably of different phylogenetic status. It is possible that further study, particularly of the so-called aberrant genera, would demand a revision, and the present arrangement of the subfamilies should be regarded as tentative and practical rather than natural.

As a family the Acrididae show remote affinity with Pauliniidae but no close relationship with the other families.

\section{TABLE III.-Subfamilies of Acrididae and their Main Characters}

\begin{tabular}{|c|c|c|c|c|c|c|c|c|}
\hline Subfamil & & & $\begin{array}{l}\text { Valves } \\
\text { of } \\
\text { penis }\end{array}$ & $\begin{array}{l}\text { Epi- } \\
\text { phallus }\end{array}$ & $\begin{array}{l}\text { Comstock- } \\
\text { Kellogg } \\
\text { glands* }\end{array}$ & $\begin{array}{c}\text { Basal lobes } \\
\text { of hind } \\
\text { femur }\end{array}$ & $\begin{array}{c}\text { Stridulatory } \\
\text { mechanism }\end{array}$ & pan \\
\hline Dericorythina & & 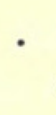 & $\begin{array}{l}\text { Paired } \\
\text { flexured }\end{array}$ & $\begin{array}{l}\text { Bridge- } \\
\text { shaped }\end{array}$ & - & $\begin{array}{l}\text { Equal } \\
\text { length }\end{array}$ & . - or + & $\begin{array}{r}\mathrm{No} \\
\mathrm{pr}\end{array}$ \\
\hline Chilacridinae & & . & Ditto & Ditto & ? & Ditto & - & - \\
\hline Romaleinae & . & 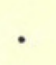 & , & ," & . + or - & , & + & . \\
\hline Lithidiinae & . & . & $\begin{array}{l}\text { Paired } \\
\text { divided }\end{array}$ & , & ? & $\begin{array}{c}\text { Lower lobe } \\
\text { shorter }\end{array}$ & - & . $\mathrm{A}$ \\
\hline Hemiacridinae & & . & Ditto & , & + & - Ditto & $\cdot+$ or - & $\begin{array}{r}\mathrm{No} \\
\mathrm{p}\end{array}$ \\
\hline Tropidopolina & & . & $\begin{array}{l}\text { Paired } \\
\text { flexured }\end{array}$ & , & + & ", & - or + & . \\
\hline Oxyinae & . & . & Ditto & $\begin{array}{l}\text { Divided } \\
\text { or with } \\
\text { tendency } \\
\text { to be } \\
\text { divided }\end{array}$ & + & ", & - & . \\
\hline Coptacridinae & & - & ", & . Divided & + & , & - & . \\
\hline Calliptaminae & & . & , & . Plate-like & + & ", & - & . \\
\hline Euryphymina & & . & , & . Divided & + & ", & - & . \\
\hline Eyprepocnemi & idinae & & , & $\begin{array}{l}\text { Bridge- } \\
\text { shaped }\end{array}$ & + & ", & - & . \\
\hline Catantopinae & & . & , & $\begin{array}{c}\text { Bridge- } \\
\text { shaped } \\
\text { sometimes } \\
\text { divided }\end{array}$ & or - & ", & - & . \\
\hline $\begin{array}{l}\text { Cyrtacantha } \\
\text { dinae }\end{array}$ & cri- & & " & $\begin{array}{l}\text { - Bridge- } \\
\text { shaped }\end{array}$ & + & , & - & . \\
\hline Egnatiinae & - & . & " & - Ditto & + & ", & . + or - & . \\
\hline Acridinae & . & - & ", & , & - & ", & . + or - & - \\
\hline Eremogryllina & & - & $"$ & - Divided & $?$ & " & + & . \\
\hline Truxalinae & . & . & ", & $\begin{array}{l}\text { Bridge- } \\
\text { shaped }\end{array}$ & - & $"$ & + & . \\
\hline
\end{tabular}




\section{Key to Subfamilies of Acrididae}

I (6) Lower basal lobe of hind femur as long as upper one or only insignificantly longer or shorter.

2 (5) First vannal area of hind wing (if present) without stridulatory specialization.

3 (4) Hind tibia curved. Median carina of pronotum raised in prozona. Cingulum of ectophallus with long apodemes. (Asia, Africa) . . . Dericorythinae

4 (3) Hind tibia not curved. Median carina of pronotum not raised. Cingulum of ectophallus with short, plate-like apodemes. (S. America) . Chilacridinae

5 (2) First vannal area of hind wing with series of parallel, transverse, finely serrated stridulatory veinlets; medial, cubital and second vannal areas expanded, with row of parallel thickened, transverse veinlets. Hind tibia not curved. Median carina of pronotum of variable shape or absent . . Romaleinae

6 (I) Lower basal lobe of hind femur distinctly shorter than upper one.

7 (8) Body depressed. Tympanum absent even in fully winged species. Mesosternal interspace very large and wide, often separated from metasternal only

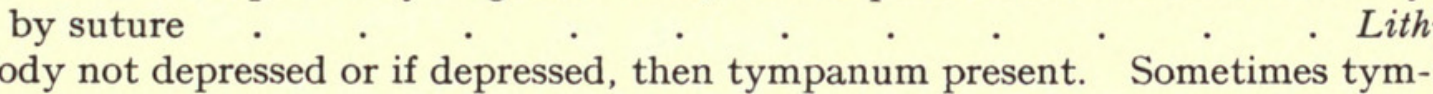
panum absent, but then body compressed or cylindrical. Mesosternal interspace variable, but well distant from metasternal.

9 (Iо) Radial area of elytron with a series of regular, parallel stridulatory veinlets (Text-fig. 22). If apterous, then body compressed and tympanum absent

Hemiacridinae

Io (9) Stridulatory veinlets of radial area of elytron absent. If apterous, then typanum (at least rudimentary) present.

II (26) Prosternal process, or collar present.

I 2 (I3) Lower external lobe of hind knee with spine-like apex (Text-fig. 24)

I3 (I2) Lower external lobe of hind knee with apex rounded, angular or subacute, but not spine-like.

I4 (I5) Last abdominal tergite in male (in majority of genera) with well developed furcula ; supra-anal plate mostly with attenuate or trilobate apex; subgenital plate with transverse fold

Coptacridinae

I5 (I4) Last abdominal tergite in male without well developed furcula; supra-anal plate variable ; subgenital plate without transverse fold.

I6 (I 7) Mesosternal interspace closed

Tropidopolinae

I7 (I6) Mesosternal interspace open.

I 8 (25) Mesosternal lobes rounded or obtusangular.

I9 (20) Male cerci pincers-like, strong, regularly incurved. Epiphallus discoidal, without lophi

Calliptaminae

20 (19) Male cerci variable, but not pincers-like. Epiphallus variable, but always with lophi.

2I (22) Male cercus with large basal articulation; posterior margin of the last abdominal tergite strongly sclerotized. Epiphallus divided, with large, mostly angular, lophi

22 (2I) Basal articulation of male cerci small. Posterior margin of the last abdominal tergite not strongly sclerotized. Epiphallus not divided, or if divided, then with comparatively small, lobiform lophi.

23 (24) Dorsum of pronotum flat or weakly tectiform, with median and lateral carinae linear (lateral carinae sometimes obliterated). Male cercus with strongly compressed lobiform or subacute apex.

Eyprepocnemidinae

24 (23) Dorsum of pronotum of variable shape; lateral carinae, if present, not linear. Male cercus variable, but not with strongly compressed lobiform or subacute apex 
26 (II) Prosternal process or collar usually absent; if present, then antenna ensiform and body strongly elongated.

27 (30) Stridulatory serration on internal side of hind femur absent.

28 (29) Furcal suture of mesosternum curved backwards in the middle, thus shortening the mesosternal interspace (Text-fig. 3I). Sides of abdominal tergites often with transverse (stridulatory) ridges $. \quad . \quad . \quad . \quad . \quad$. Egnatiinae

29 (28) Furcal suture of mesosternum of normal shape. No stridulatory specialization on sides of abdominal tegites.

Acridinae

30 (27) Stridulatory serration on internal side of hind femur present.

3I (32) Male cercus strongly thickened in basal part with strongly incurved apex

32 (3I) Male cercus simple, mostly conical

Eremogryllinae . Truxalinae

\section{Subfamily Dericorythinae}

(Text-fig. I8)

Type genus : Dericorys Serville, I 838

Size large, medium or small. Head variable. Pronotum with strong crest or at least hump in prozona only. Prosternal process or collar present. Mesosternal interspace open. Elytra and wings fully developed, shortened, lobiform or absent.

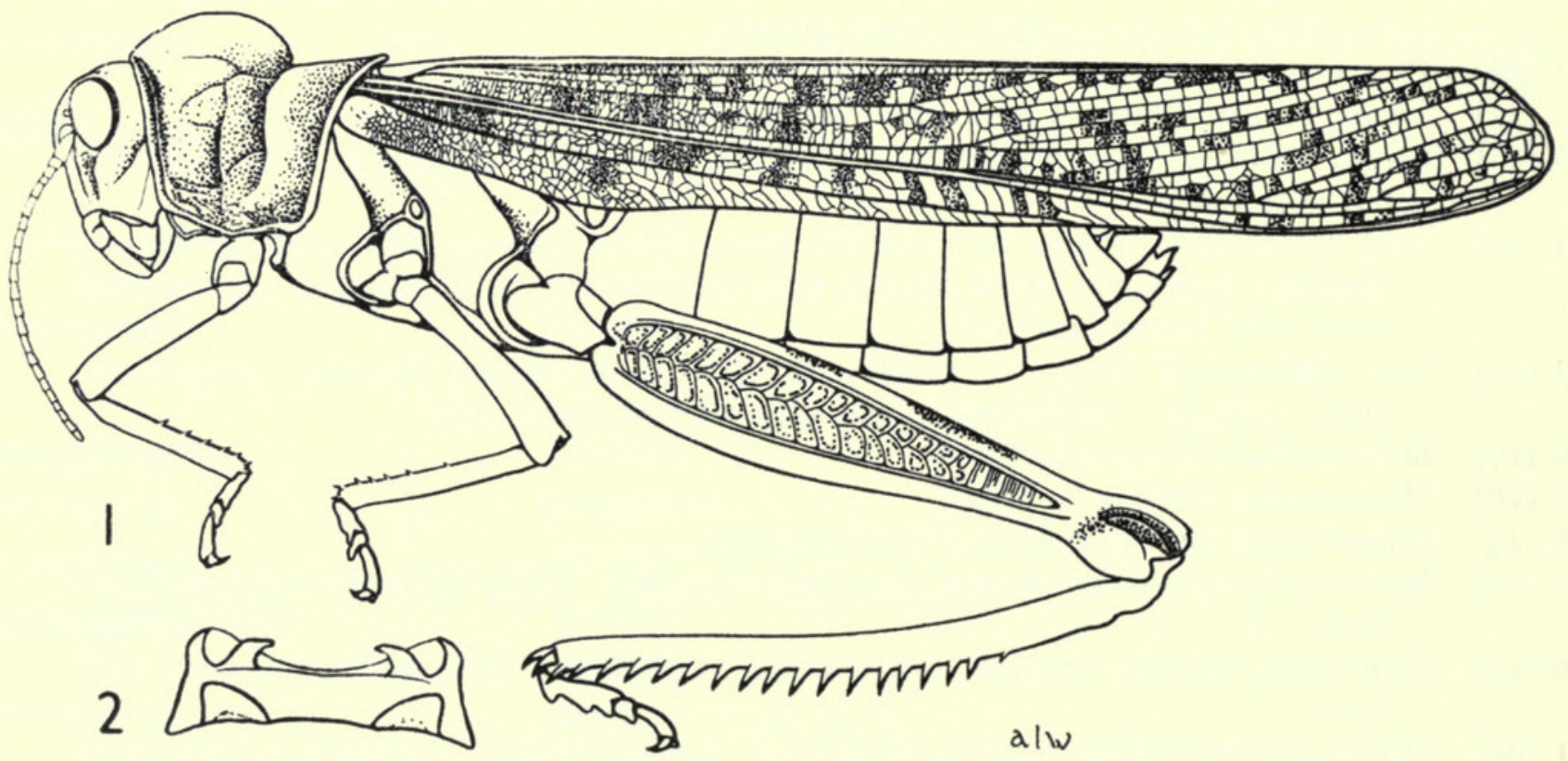

FIG. I8. I. Dericorys albidula Serv., female. 2. Epiphallus of Dericorys tibialis (Pall.).

Tympanum present or (in apterous species) absent. Lower basal lobe of hind femur as long as, or slightly longer than, upper one. Hind tibia curved; external apical spine present. Basal and apical valves of penis connected by flexure. Epiphallus bridge-shaped, with ancorae and lophi. Stridulatory mechanism not found, except in one species, in which it is represented by inflated part of subcostal area of hind wing.

This subfamily was erected by Jakobson (Jakobson \& Bianki, I904), but was disregarded by the later authors, who placed the subfamily into Catantopinae. 
Dericorythinae are remarkable in that the shape of the lower basal lobe of the hind femur is of the same length as or slightly longer than the upper one, a condition found also as a normal feature in Romaleinae and Chilacridinae only amongst other subfamilies of Acrididae. It is not possible to retain Dericorythinae in Catantopinae because of the shape of the basal lobes of the hind femur, nor is it possible to regard them as a family, since all the families with this type of femur are characterized by other features, such as the phallic complex, fastigial furrow, and stridulatory mechanism.

Dericorythinae are distributed in SW. and central Asia and Northern Africa.

\section{List of examined genera:}

I. Anamesacris Uvarov, 1934

2. Bolivaremia Morales-Agacino, 1949

3. Corystoderes I. Bolivar, I936
4. Dericorys Serville, 1838

5. Pamphagulus Uvarov, 1929

\section{Subfamily Chilacridinae}

\section{(Text-fig. I9) \\ Type genus : Chilacris Liebermann, 1943}

Of medium size, integument rugose. Antenna filiform. Head subglobular; fastigium of vertex mostly with faint trace of fastigial furrow. Three sulci crossing dorsum of pronotum. Prosternal process present. Meso- and metasternal interspace short and wide. Elytra and wings fully developed, reduced or absent. Tympanum normally present. Lower basal lobe of hind femur as long as or slightly longer than upper one. External apical spine of hind tibia absent or present. Ectophallus membraneous; cingulum poorly sclerotized, plate-like, with apodemes wide, short, plate-like, poorly differentiated; sheath of penis wide, covering whole apical valves of penis. Endophallus strongly sclerotized; basal valves of penis form long posterior projections, distal ends of which meet distal ends of apical valves of penis, proximal part of them plate-like, widened ; proximal ends of apical valves of penis close to lower part of basal valves ; they are connected by short flexure. Spermatophore sac placed in space between posterior projections of basal valves and apical valves of penis ; ejaculatory sac partly below, partly between proximal parts of basal valves of penis. Epiphallus bridge-shaped, with strong, non-articulated ancorae and strong, hook-shaped lophi. Oval sclerites present. Spermatheca variable, with widened single distal end or forming apical and preapical diverticula.

This subfamily was erected by Liebermann and called Chilacrinae in I942, but the name has to be amended to Chilacridinae. He included in it four genera: Aucacris Hebard, I929, Chilacris Liebermann, I943, Philippiacris Liebermann, I943, and Elasmoderus Saussure, I888. Later the genus Uretacris Liebermann, I943, was included in the subfamily and Elasmoderus was excluded (Liebermann, I959, in litt.). Bufonacris Walker, I87I, should also be included here.

Dr. J. Liebermann kindly sent me the types of his genera and I was able to study the phallic complex and spermatheca. The phallic complex proved to be of 
peculiar structure, which was not found in other families and subfamilies of Acridoidea. The most striking features are : firstly, the poorly developed cingulum, which resembles that in the primitive families Tanaoceridae, Xyronotidae and Pneumoridae; secondly, the peculiar shape of the endophallus, with the basal valves of

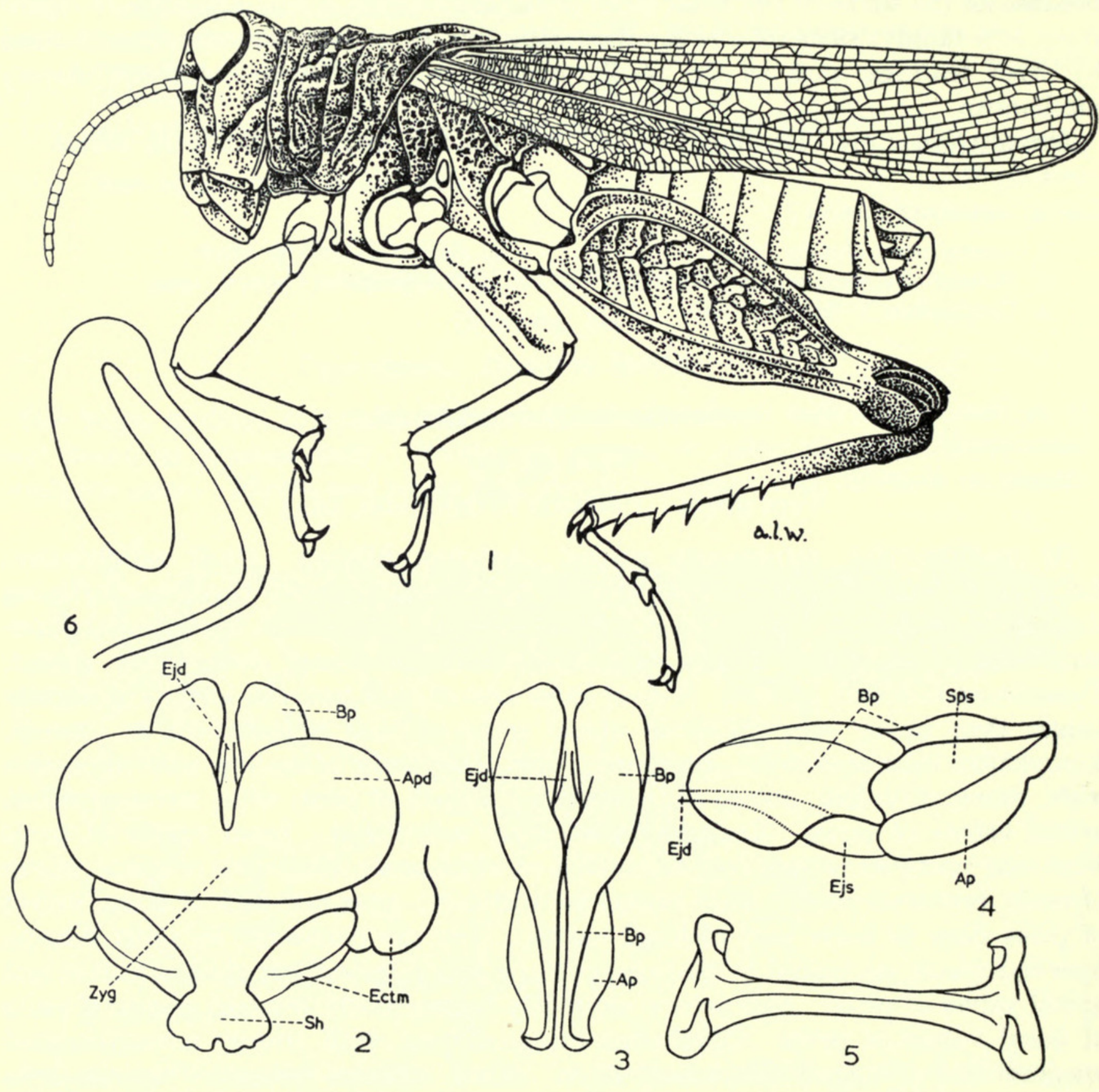

FIG. 19. Chilacris maculipennis Lieb., male type. 2-5. Philippiacris rubiosus Lieb. 2. Ectophallus, from above (whole proximal part of ectophallic membrane and epiphallus removed). 3. Endophallus, from above. 4. Endophallus, lateral view. 5. Epiphallus. 6. Chilacris maculipennis, spermatheca.

the penis forming long posterior projections, which extend to the point of meeting of the apices of the apical valves of the penis, with the spermatophore sac located between them. These general features of the phallic complex are similar in all studied genera of the subfamily, though they vary in details. The phallic complex of 
Philippiacris is figured (Text-fig. I9), since the several specimens of this genus were in the best condition for dissecting and drawing.

It is difficult to suggest the position and relationship of Chilacridinae with other groups of Acridoidea. Their genitalia are quite peculiar without a close parallel in the rest of Acridoidea. The shape of the basal lobes of the hind femur suggest a possible link with Romaleinae and Dericorythinae. Tentatively, Chilacridinae are placed in the family Acrididae, but further detailed studies of South American Acridoidea are needed to establish their exact position.

\section{List of known genera :}

I. Aucacris Hebard, 1929

2. Bufonacris Walker, $187 \mathrm{I}$

3. Chilacris Liebermann, I943

4. Philippiacris Liebermann, 1943

5. Uretacris Liebermann, I943

\section{Subfamily Romaleinae}

\section{(Text-fig. 20)}

\section{Type genus : Romalea Serville, I83I}

Size mostly large or medium. Body of variable shape. Head of variable shape. Prosternal process present. Mesosternal interspace open. Highly specialized stridulatory mechanism present : first vannal area of hind wing narrow, convex, forming tube-like fold, when the wing is folded; this area has arched, parallel, finely, but strongly serrated, transverse veinlets-sometimes adjoining longitudinal veins are serrated as well ; cubital, second vannal and sometimes medial area are expanded, with thickened, regular, transverse veinlets. Lower basal lobe of hind femur about as long as upper one. External apical spine of hind tibia present or absent. Basal and apical valves of penis connected by strong, thickened flexure. Epiphallus robust, bridge-shaped, with short ancorae and lophi.

The subfamily Romaleinae was established by Roberts (I94I) on the basis of the phallic complex, but although this character alone is not sufficient for separating the subfamily, several other characters support its status, in particular the peculiar stridulatory mechanism which occurs only in this subfamily and may be traced even in the strongly reduced wings of micropterous species. Sometimes it may be reduced as in Aplatacris or strongly reduced as in Munatia, in which only weak traces of the serration may be observed. Another character, which occurs elsewhere in Acrididae, as a stable normal character, only in Dericorythinae and Chilacridinae is the lower basal lobe of the hind femur being as long as the upper one. Yet another character is the flexure of the valves of the penis being more robust than is usual in other Acrididae.

Members of the Romaleinae present the same extreme diversity in the shape of the body and in general appearance as the other large subfamilies. There are amongst them some forms strikingly similar to certain representatives of the Pamphagidae (Phrynotettix, Dracotettix), and of the Acridinae (such as Legua, which superficially resembles Acrida; Callonotacris, which superficially resembles Pyrgodera); and Tropidacris and allied genera which are very similar to Cyrtacanthacridinae. 


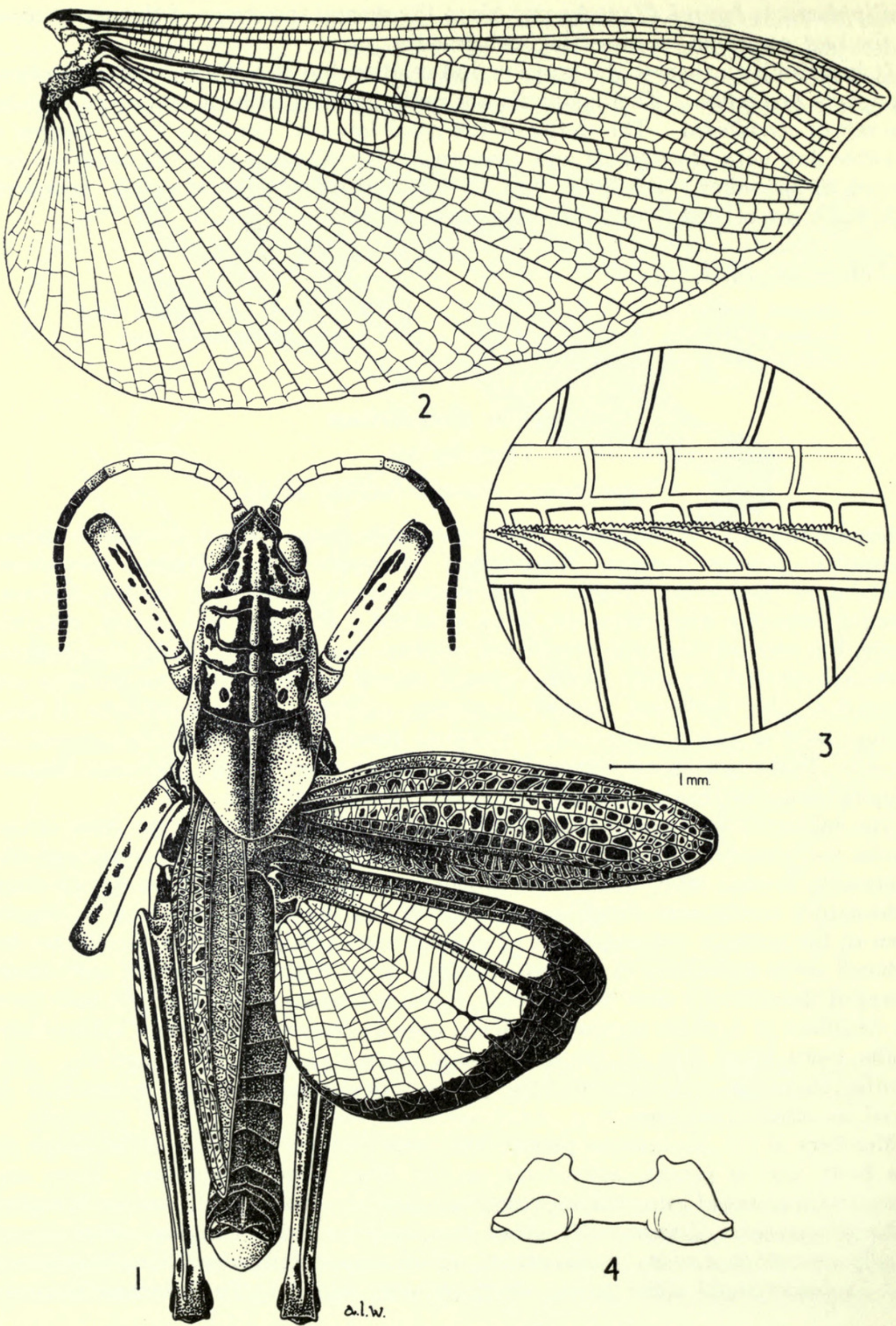

FIG. 20. I. Romalea microptera (Beauv.), male. 2. Wing of Colpolopha obsoleta Serv. 3. Part of the stridulatory mechanism under large magnification. 4. Epiphallus of Romalea microptera. 
Romaleinae occur mainly in S. America with a few in N. America, but several genera are known from NE. Africa and S. Asia.

\section{List of examined genera:}
I. Acrostegastes Karsch, 1896
2. Aeolacris Scudder, 1875
3. Agriacris Walker, 1870
4. Alcamenes Stål, 1878
5. Alophonota Stål, I 873
6. Antandrus Stål, 1878
7. Aplatacris Scudder, I 875
8. Brachystola Scudder, I 876
9. Callonotacris Rehn, I909
Io. Chariacris Walker, I870
II. Chromacris Walker, I870
I2. Cibotopteryx Rehn, 1905
13. Colpolopha Stål, I873
I4. Coryacris Rehn, I909
I5. Draconata Pictet \& Saussure, I 887
I6. Dracotettix Bruner, I 889
17. Eurynotacris Ramme, I93I
I8. Eutropidacris Hebard, I923
19. Kabulia Ramme, 1928
20. Legua Walker, I 870
21. Lophacris Scudder, I 869
22. Lyrotyloides Bey-Bienko, 1956
23. Lyrotylus Uvarov, 1923
24. Munatia Stål, I 875
25. Pelecinotus I. Bolivar, I88 I
26. Phrynotettix Glover, 1872
27. Prionacris Stål, $\mathbf{1} 878$
28. Prionolopha Stål, I 873
29. Procolpia Stål, I 873
30. Robecchia Schulthess, 1898
31. Romalea Serville, I831
32. Taeniopoda Stål, I 873
33. Teratodes Brulle, $\mathrm{I} 835$
34. Titanacris Scudder, 1869
35. Tropidacris Scudder, 1869
36. ? Tropidostethus Philippi, I 863
37. Tytthotyle Scudder, I 897
38. Xestotrachelus Bruner, I9I 3
39. Xyleus Gistl, 1848
4c. Zoniopoda Stål, I 873

\section{Subfamily Lithidiinae nov.}

(Text-fig. 2I)

\section{Type genus : Lithidium Uvarov, I925}

Small or medium size, robust, body depressed. Male much smaller than female. Antenna filiform or slightly thickened in apical part. Head subglobular. Fastigium of vertex short, wide. Pronotum short, wide, depressed. Prosternal collar present or absent. Mesosternal interspace very large, close or fused with the metasternal or separated from it only by suture. Elytra and wings present or absent. Tympanum absent. Lower lobe of hind femur shorter than upper one. External apical spine of hind tibia present or absent. Valves of penis paired, divided; apical ones being thin and reduced. Epiphallus bridge-shaped, with short ancorae and short, hook-shaped lophi. Stridulatory mechanism not found.

Only four genera of this family are known. The first one, Eneremius was placed by Saussure in the "Strips Eremobia", then of the subfamily Oedipodinae. Uvarov (I925) removed it, with Lithidium, to the tribe Thrinchini, then of Oedipodinae, but in 1943 he transferred the tribe to Pamphagidae. Dirsh (I956) referred these two genera and Lithidiopsis tentatively to the family Lentulidae. The only winged genus, Microtmethis, was described by Karny as a member of the Oedipodinae. The males of Lithidium and of Microtmethis have only recently become available. In the phallic complex they proved to be very similar to one another, but strongly different from the Lentulidae and from all other known subfamilies of Acrididae, except perhaps Hemiacridinae.

In the divided valves of the penis the Lithidinae approximate to Hemiacridinae, 


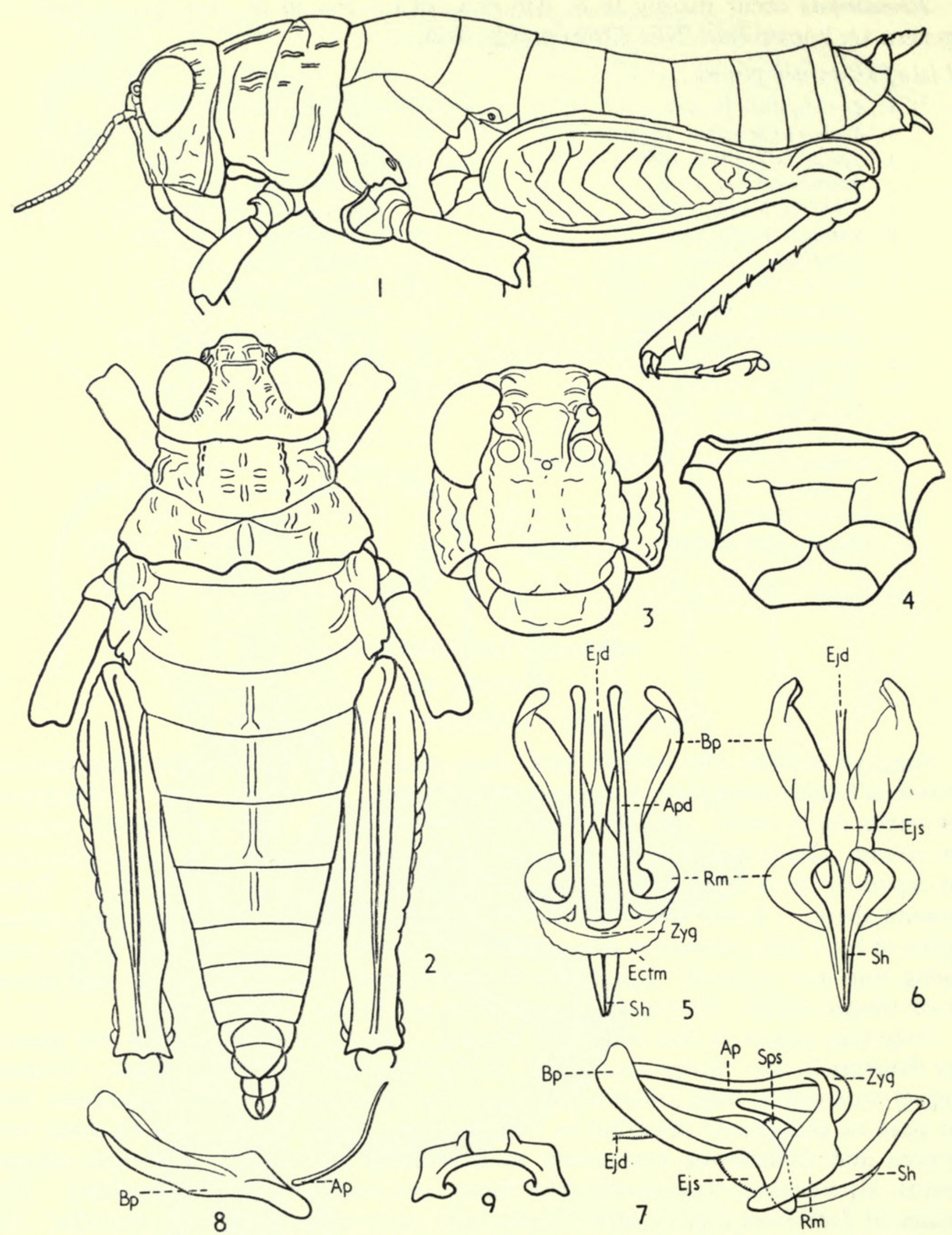

FIG. 2I. I-4. Lithidium bushmanicum Dirsh. I. Female, in profile. 2. The same, from above. 3. Face. 4. Meso- and metasternum. 5-9. Phallic complex of Lithidium pusillum Uv. 5. From above. 6. From below. 7. In profile. 8. Penis, in profile. 9. Epiphallus. 
but the apical valves are strongly reduced. The epiphallus is rather simplified, with narrow bridge and simple, small ancorae and lophi. The latter character, the shape of the meso- and the metasternum and the absence of the tympanum even in winged species, preclude placing the Lithidiinae in Hemiacridinae.

The subfamily is found in S. and SW. Africa only.

List of known genera :

I. Lithidium Uvarov, 1925

2. Lithidiopsis Dirsh, 1956

3. Microtmethis Karny, I910

4. ?Eneremius Saussure, I 888. (Known from females and its subfamily position is uncertain)

\section{Subfamily Hemiacridinae}

(Text-fig. 22)

\section{Type genus : Hemiacris Walker, 1870}

Body of variable shape. Head prognathous, orthognathous or opisthognathous. Prosternal process present. Mesosternal interspace open or closed. Elytra and wings fully developed, reduced or absent; radial area of elytron with series of regular, thickened, transverse, stridulatory veinlets. Tympanum present, in apterous forms absent. Lower basal lobe of hind femur shorter than upper one. External apical spine of hind tibia present or absent. Basal and apical valves of penis disconnected, but sometimes there is a tendency to form flexure. Epiphallus bridgeshaped, sometimes with divided bridge; ancorae and lophi present.

The subfamily was established recently by Dirsh (I956) on the basis of divided valves of the penis and the presence of a peculiar stridulatory mechanism. The first character is shared with Lithidiinae and also links them to some extent with Tropidopolinae, which have a tendency towards disappearance of the flexure. The peculiar stridulatory mechanism does not occur in other subfamilies of Acrididae.

The subfamily is distributed in the tropics and subtropics of Africa, Asia, the Australasian Archipelago and Australia, and there are two genera in S. America. List of examined genera :
I. Acanthoxia I. Bolivar, I906
2. Aleuas Stål, 1878
3. Bermius Stål, I 878
4. Calviniacris Dirsh, 1956
5. Castetsia I. Bolivar, I902
6. Clonacris Uvarov, 1943
7. Diademacris Ramme, 1929
8. Dirshacris Brown, 1959
9. Gesonula Uvarov, I940
Io. Glauningia Ramme, I929
II. Hemiacris Walker, I870
I2. Hemipristocorypha Dirsh, 1952
13. Hievoglyphus Krauss, I877
I4. Kassongia I. Bolivar, I908
I5. Leatettix Dirsh, 1956
I6. Leptacris Walker, I87o
I7. Lopheuthymia Uvarov, 1943
18. Loryma Stål, I 878
19. Malagasacris Rehn, I944

20. Merehana Kevan, I957

21. Mesopsera I. Bolivar, 1908

22. Oraistes Karsch, $\mathrm{I} 896$

23. Parahieroglyphus Carl, I9I6

24. Paraspathosternum Ramme, 1929

25. Pareuthymia Willemse, I930

26. Perakia Ramme, I930

27. Phalinus Rehn, I944

28. Pristocorypha Karsch, I896

29. Pseudocarsula Kirby, I9I4

3o. Spathosternum Krauss, 1877

3I. Sudanacris Uvarov, 1944

32. Tarbaleus Brunner, 1898

33. Tauchira Stål, I 878

34. Uvarovidium Dirsh, 1956

35. Willemsella Miller, 1934

36. Xenippa Stål, I 878

37. Zygoclistron Rehn, I905

ENTOM. Iо, 9. 

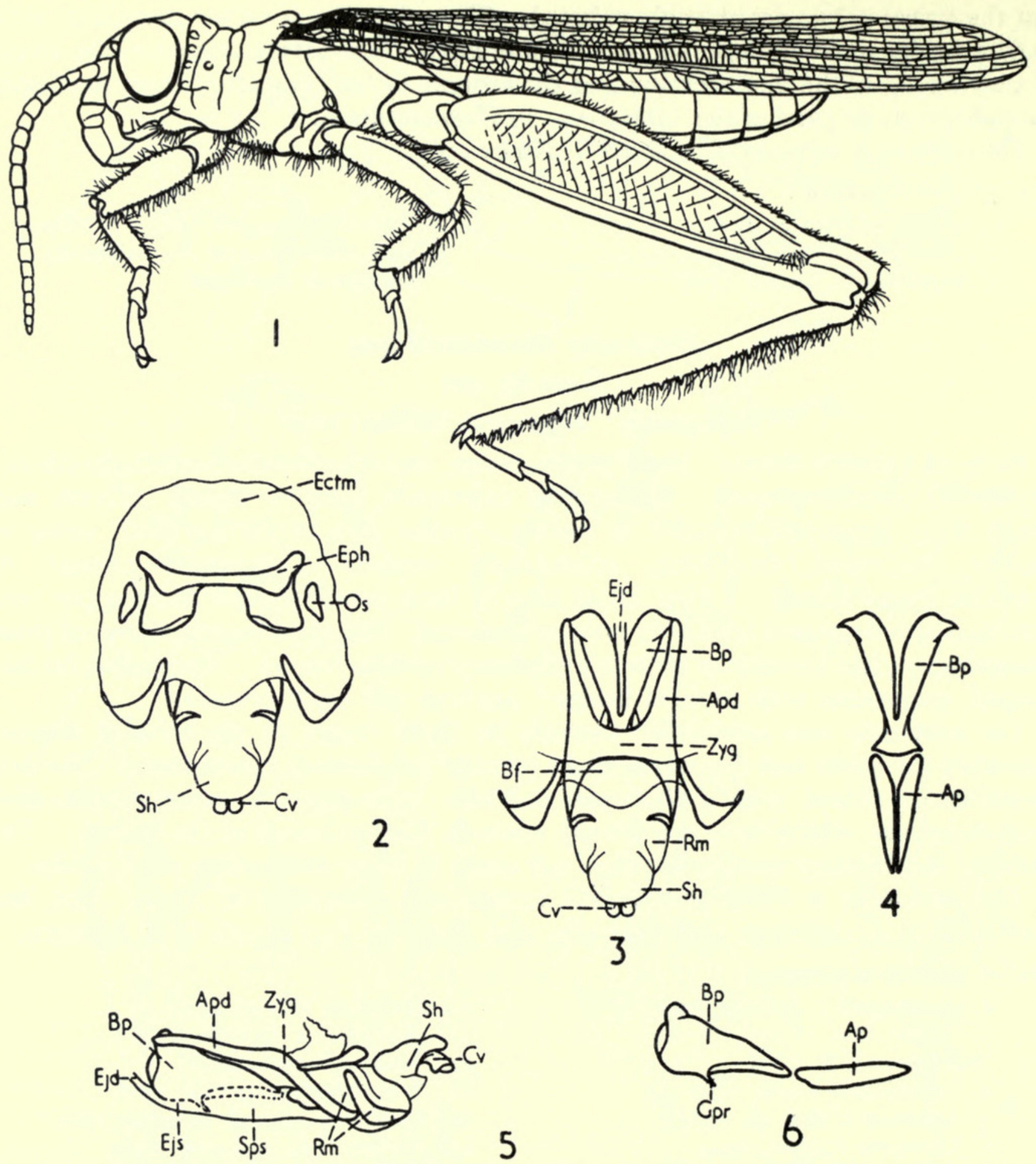

FIG. 22. Hemiacris fervens Walk. I. Male. 2-6. Phallic complex. 2. Whole phallic complex from above. 3. The same, but ectophallic membrane and epiphallus removed. 4. Penis, from above. 5. As the fig. 3 , but in profile. 6. Penis, in profile.

\section{Subfamily Tropidopolinae}

(Text-fig. 23)

Type genus : Tropidopola Stål, 1873

Body cylindrical, elongated (sometimes strongly). Head from strongly elongated and acutely conical to subglobular. Median and lateral carinae of pronotum present or absent. Prosternal process beak-like or cylindrical or with widened, flat or concave 
REVISION OF THE FAMILIES AND SUBFAMILIES OF ACRIDOIDEA 399 apical surface. Mesosternal interspace closed. Elytra and wings fully developed or reduced. Tympanum present. Lower basal lobe of hind femur shorter than upper one. External apical spine of hind tibia present. Male cercus of variable shape. Flexure between basal and apical valves of penis has tendency to disappear. Epiphall-

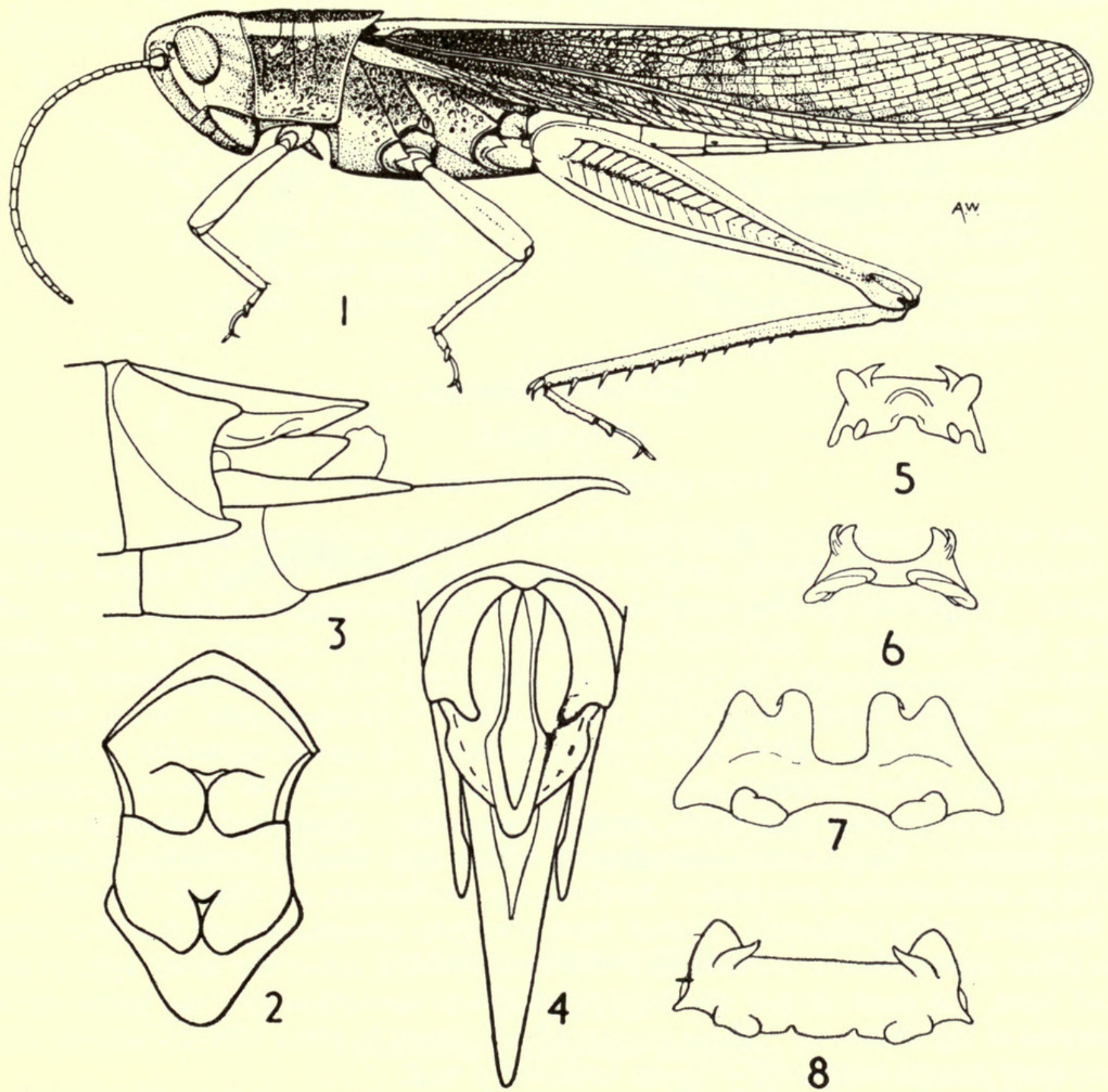

FIg. 23. I-4. Afroxyrrhepes acuticercus Dirsh. I. Male. 2. Meso- and metasternum. 3. End of abdomen, in profile. 4. The same, from above. 5-8. Epiphalli. 5. Tropidopola cylindrica (Marsh.). 6. Tristria lacerta St. 7. Homoxyrrhepes punctipennis (Walk.). 8. Afroxyrrhepes procera (Burm.).

us bridge-shaped, sometimes divided; ancorae and lophi present. Stridulatory mechanism sometimes present (thickened veinlets in costal and subcostal areas of elytron).

There are four features, the combination of which characterizes this subfamily. These are the closed mesosternal interspace, the presence of an external apical spine 
on the hind tibia, a tendency towards losing the flexure between the basal and apical valves of the penis, and the shape of the prosternal process. None of these characters could be regarded as absolute, since they can be found separately in other subfamilies of Acrididae. However, their combination defines the Tropidopolinae as a natural group.

This subfamily is distributed in S. Asia and Africa, and with one genus reaching S. Europe.

\section{List of examined genera :}

I. Afroxyrrhepes Uvarov, 1943

8. Musimoja Uvarov, 1953

2. Bambusacris Henry, 1933

3. Calamippa Henry, 1940

9. Oxyrrhepes Stål, I873

4. Chloroxyrrhepes Uvarov, 1926

Io. Petamella Giglio-Tos, 1907

5. Homoxyrrhepes Uvarov, I 926

I I. Tinnevellia Henry, I940

6. Limnippa Uvarov, I94I

7. Mesopsilla Ramme, I929

12. Tristria Stål, I873

13. Tropidopola Stål, I873

\section{Subfamily Oxyinae}

(Text-fig. 24)

Type genus Oxya Serville, I83I

Size small or medium. Head subconical ; fastigium of vertex short. Pronotum cylindrical or subcylindrical ; median carina weak, linear or absent ; lateral carinae absent. Prosternal process conical. Mesosternal interspace open. Elytra and wings fully developed, shortened or absent. Tympanum present. Two or three distal abdominal sternites (in the majority of genera) with brush-like lateral groups of hairs. Lower basal lobe of hind femur shorter than upper one ; lower lobe of hind knee spine-like. Hind tibia (in the majority of cases) expanded; external apical spine (except Gerista) present. Valves of ovipositor and female subgenital plate (in most genera) with teeth, spines or serration. Basal and apical valves of penis flexured. Epiphallus bridge shaped, with bridge divided or with tendency to division, with ancorae and lophi. Stridulatory mechanism not found.

Members of the subfamily Oxyinae form a natural assemblage which differs from the other subfamilies of Acridoidea in the presence of a spine-like lower lobe of the hind knee, the more or less divided bridge of the epiphallus and the hairy distal sternites of the abdomen. These characters are found in other subfamilies also, but their combination defines the Oxyinae reasonably well.

The subfamily Oxyinae is distributed in Africa, Asia and Australia.

List of examined genera :

I. Austiniella Ramme, I93I

2. Badistica Karsch, I89I

3. Caledonia Willemse, I923

4. Caryanda Stål, I878

5. Cercina Stål, I 878

6. Chitaura I. Bolivar, I9I 8

7. Dapperia Sjöstedt, I92I

8. Dibastica Giglio-Tos, 1907

9. Digentia Stål, I878

ro. Genditia I. Bolivar, I9I I

II. Gerista I. Bolivar, I905

I2. Lucretilis Stål, I 878

13. Oxya Serville, I83I

I4. Pterotiltus Karsch, I893

I5. Quilta Stål, I860

16. Racilia Stål, 1878

17. Zulua Ramme, I929 


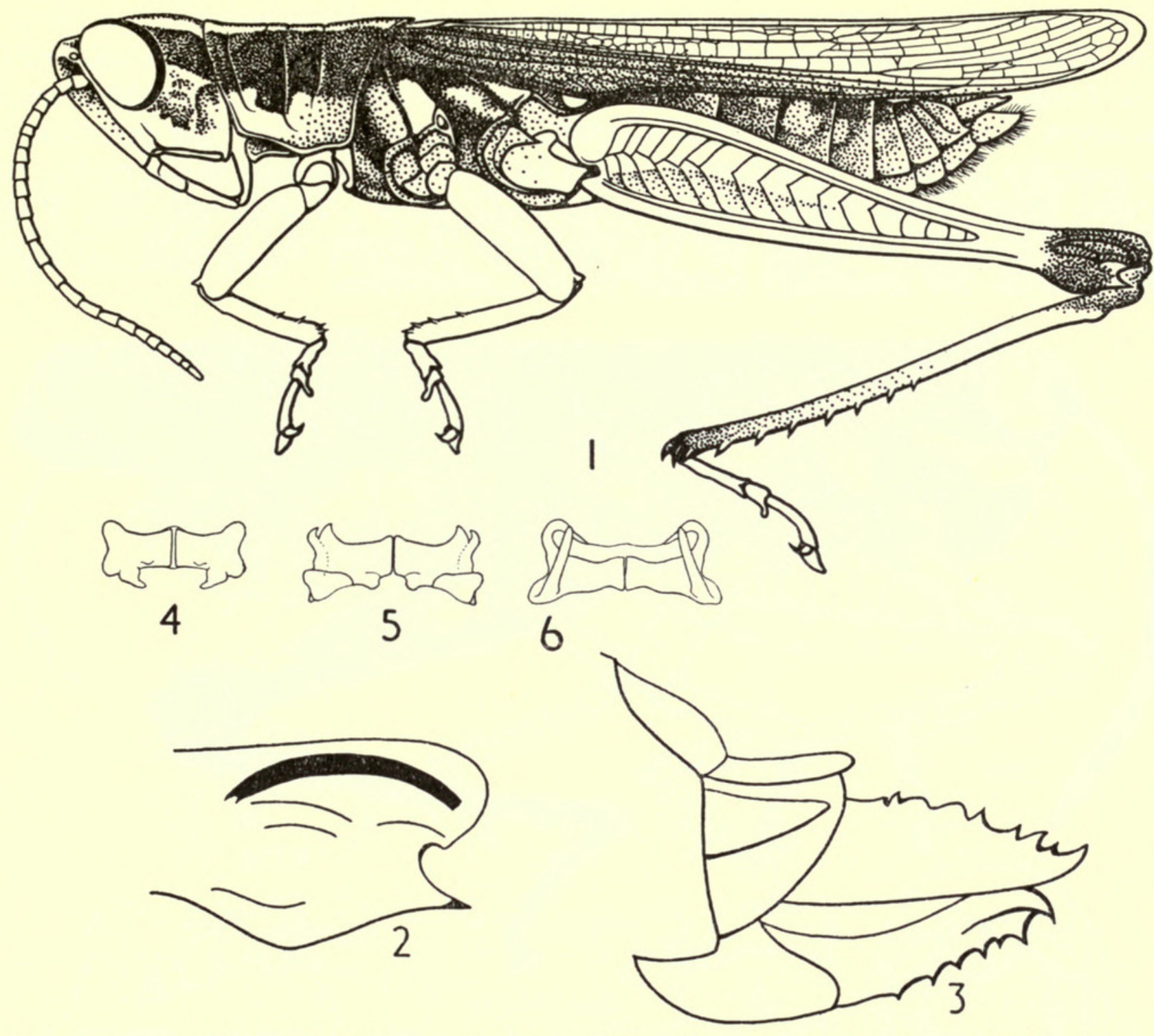

FIG. 24. I-3. Oxya hyla Serv. I. Male. 2. Hind knee, external side. 3. Ovipositor. 4-6. Epiphallus. 4. Oxya hyla Serv. 5. Dibastica major I. Bol. 6. Pterotiltus inuncatus (Karsh).

\section{Subfamily Coptacridinae}

(Text-fig. 25)

Type genus : Coptacra Stål, I873

Size small or medium. Head subconical; occiput forming angle with vertex, mostly separated by ridge. Pronotum without lateral carinae. Prosternal process conical. Mesosternal interspace open. Elytra and wings fully developed or reduced. Tympanum present. Lower basal lobe of hind femur shorter than upper one. External apical spine of hind tibia absent. Last abdominal tergite of male mostly with furcula; supra-anal plate mostly with attenuate apex; subgenital plate with transverse fold. Male cercus widened in basal and compressed in apical half, with downcurved or complicatedly shaped apex. Basal and apical valves of penis flexured. Epiphallus bridge-shaped, with divided bridge ; ancorae and lophi present. Stridulatory mechanism not found. 
The subfamily Coptacridinae was regarded as a group (Brunner, I893), later as a tribe (Mistshenko, I952), of Catantopinae, but when the characters were studied in more detail, it became necessary to separate it as a subfamily. The combination of characters is as follows: the divided bridge of the epiphallus; the presence, in the majority of genera, of a furcula on the last abdominal tergite of the male ; the peculiar shape of the supra-anal plate and male cercus; a transverse fold in the subgenital plate of the male, and the separation of vertex and occiput. The two last characters are apparently peculiar to the Coptacridinae.

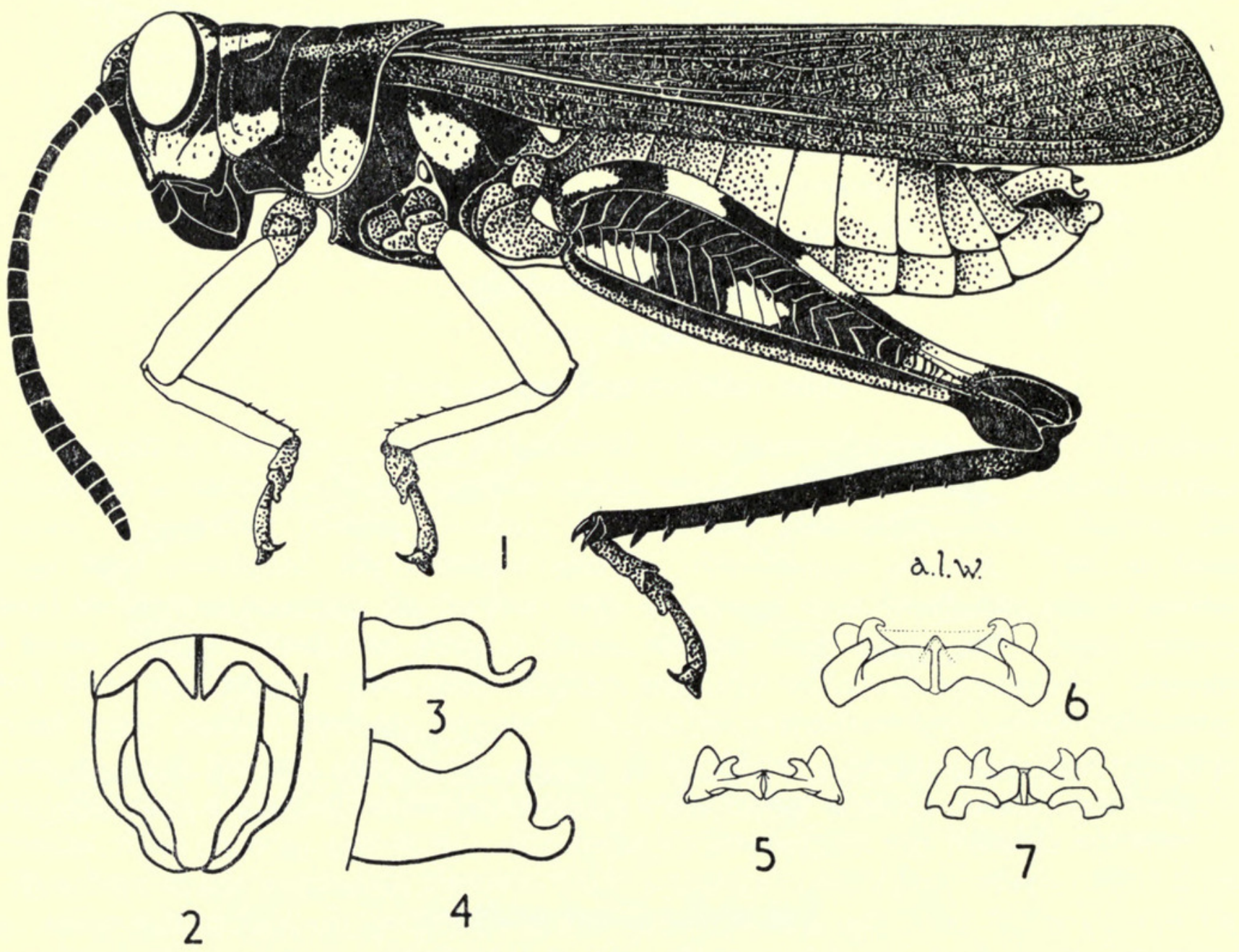

Fig. 25. I-3. Cyphocerastis laeta Karsch. I. Male. 2. End of abdomen from above. 3. Left cercus. 4. Eucoptacra anguliflava (Karsch), left cercus. 5-7. Epiphalli. 5. Coptacra ensifera I. Bol. 6. Poecilocerastis striata Ramme. 7. Eucoptacra praemorsa St.

The subfamily is distributed in tropical Africa and Asia.

List of examined genera :
I. Apalacris Walker, I87o
2. Bocagella I. Bolivar, I 889
3. Coptacra Stål, I 873
4. Cyphocerastis Karsch, I89I
5. Dubitacris Henry, 1938
6. Epistaurus I. Bolivar, I889
7. Eucoptacra I. Bolivar, 1902
8. Exochodeves I. Bolivar, I88I
9. Opharicus Uvarov, I940
Io. Paracoptacra Karsch, 1896
II. Parepistaurus Karsch, I896
I2. Poecilocerastis Ramme, I929
I3. Ruwenzoracris Rehn, I9I4
I4. Traulia Stål, I873




\section{Subfamily Calliptaminae}

(Text-fig. 26)

Type genus : Calliptamus Serville, I83I

Size small to medium. Head subconical to subglobular; frons in majority of genera vertical; fastigium of vertex roundly merging with frontal ridge ; interocular distance wide. Pronotum with median and lateral carinae (lateral ones

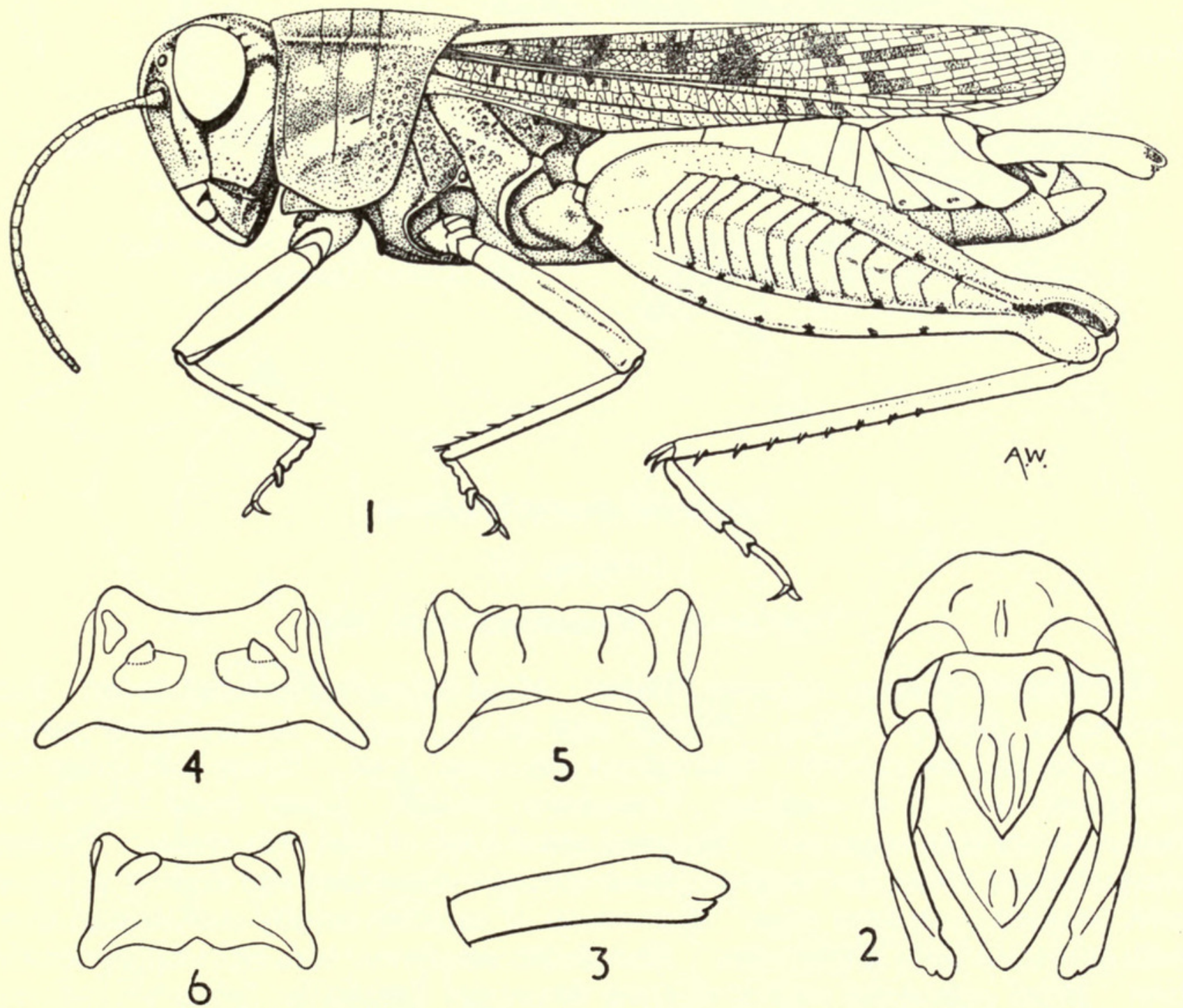

FIG. 26. I-3. Calliptamus italicus (L.). I. Male. 2. End of abdomen from above. 3. Male left cercus. 4-6. Epiphalli. 4. Calliptamus italicus (L.) 5. Sphodromerus tuareg Uv. 6. Caloptenopsis glaucopsis (Walk.).

sometimes obliterated); dorsum crossed by three sulci. Prosternal process cylindrical, conical or antero-posteriorly compressed. Mesosternal interspace open. Elytra and wings fully developed or reduced. Tympanum present. Hind femur usually wide, its lower basal lobe shorter than upper one. External apical spine of hind tibia absent. Two last abdominal tergites of male fused, inflated and upcurved. Cercus large, strong, incurved, bilobate, adapted for gripping. Basal and apical 
valves of penis flexured. Epiphallus plate-like, mostly trapezoidal, with ancorae and without lophi. Stridulatory mechanism not found.

The subfamily Calliptaminae was erected by Jakobson (Jakobson \& Bianki, I904), but was disregarded as such by the majority of later authors; Mistshenko (I952) treated it as a tribe of Catantopinae. The representatives of this subfamily have a very characteristic plate-like epiphallus, not known in other subfamilies of Acrididae. The pincer-like male cerci also are peculiar, without close parallel in other subfamilies.

Calliptaminae are distributed in Europe, Africa and Asia.

\section{List of known genera :}

I. Acorypha Krauss, 1877

2. Bosumia Ramme, 1929

3. Bothrocaracris Uvarov, 1954

4. Brachyxenia Kirby, I9I4

5. Caloptenopsis I. Bolivar, I 889

6. Calliptamus Serville, I83I

7. Indomerus Dirsh, I95I

\author{
8. Palaciosa C. Bolivar, I93o \\ 9. Paracaloptenus I. Bolivar, 1876 \\ го. Peripolus Martinez, 1902 \\ II. Sphodromerus Stål, I873 \\ I2. Sphodronotus Uvarov, I943 \\ I3. Stobbea Ramme, I929
}

\section{Subfamily Euryphyminae}

(Text-fig. 27)

\section{Type genus : Euryphymus Stål, I873}

Size small to medium. Antenna filiform. Head subconical to subglobular. Frons vertical or slightly oblique. Median and lateral carinae of pronotum present. Prosternal process present. Mesosternal interspace open. Elytra and wings fully developed, reduced or vestigial. Tympanum present. Lower basal lobe of hind femur shorter than upper one. External apical spine of hind tibia absent. Posterior margin of last abdominal tergite of male strongly sclerotized and slightly upcurved, with serrated or toothed edge. Male cercus of variable, mostly complicated shape, with expanded basal articulation. Ectophallic membrane with secondary sclerotization. Basal and apical valves of penis flexured. Epiphallus bridge-shaped, with divided bridge, lobiform ancorae and very large, tooth-shaped or elongate-lobiform lophi. Stridulatory mechanism not found.

The subfamily Euryphyminae was erected (Dirsh, I956) mainly on the basis of the structure of the epiphallus, which is divided and has peculiar lophi, and the characteristic structure of the male cerci, with specialized basal articulation, which allows a wider range of movement of the cerci than in other groups. In both respects the subfamily is so well separated from all other subfamilies of Acrididae that it might be regarded as a family. However, the flexured basal and apical valves of the penis suggest that the Euryphyminae belong to the family Acrididae.

The subfamily Euryphyminae is distributed in S., SW., and E. Africa. 


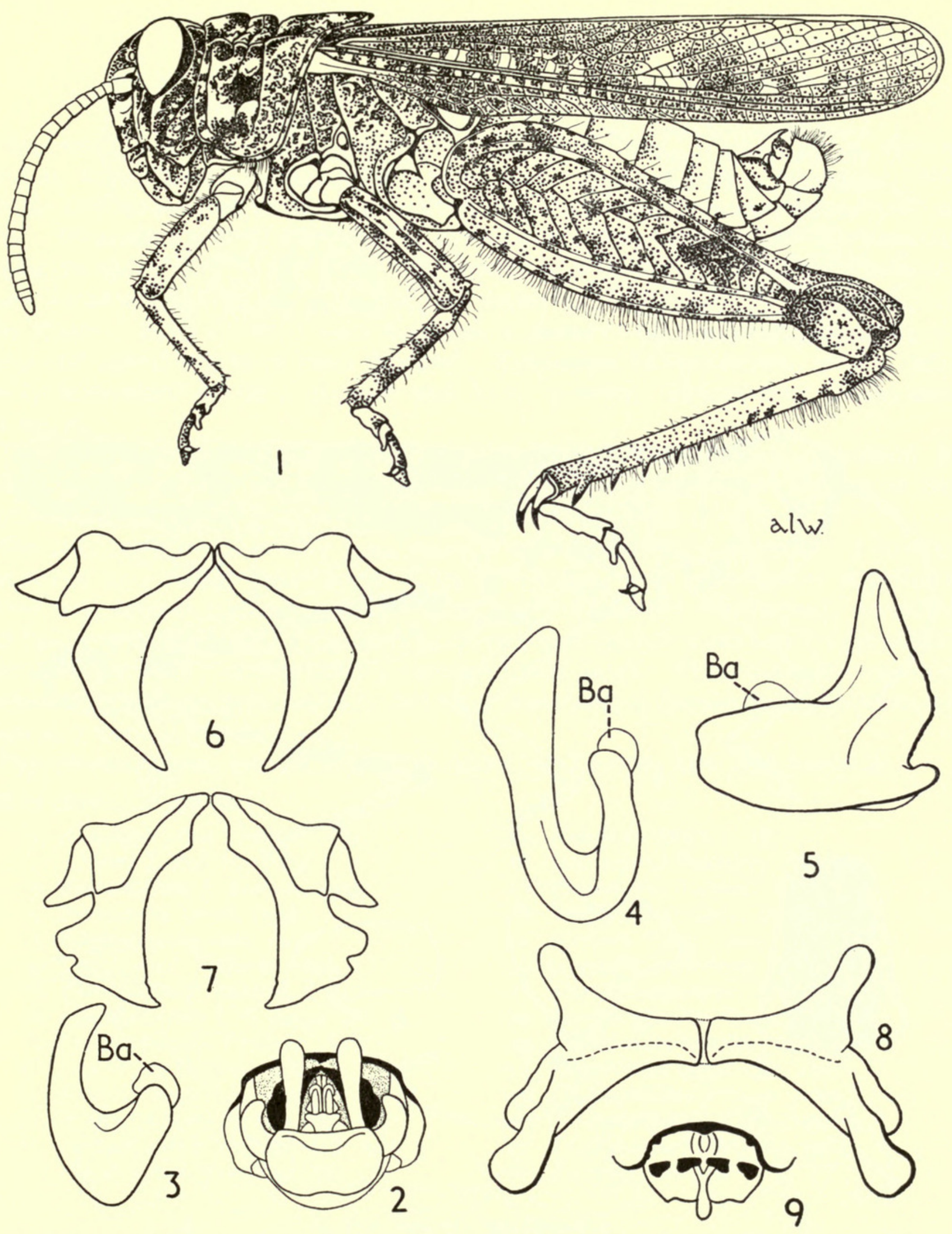

FIG. 27. I. Euryphymus haematopus (L.), male. 2. Amblyphymus rubripes Uv., posterior end of male abdomen in precoital position, showing position of supra-anal plate (dotted), epiphallus (black) and cerci. 3-5. Cerci. 3. Brachyphymus vylderi St. (Ba, basal articulation). 4. Amblyphymus miniatus Uv. 5. Acrophymus ocreatus Uv. 6-8. Epiphalli. 6. Brachyphymus vylderi St. 7. Amblyphymus miniatus Uv. 8. Acrophymus ocreatus Uv. 9. Posterior margin of the last abdominal tergite and supra-anal plate of Amblyphymus miniatus Uv., showing strong sclerotization. 


\section{List of known genera :}

I. Acoryphella Giglio-Tos, I907

2. Acrophymus Uvarov, 1922

3. Amblyphymus Uvarov, 1922

4. Anabibia Dirsh, 1956

5. Aneuryphymus Uvarov, I922

6. Brachyphymus Uvarov, 1922

7. Calliptamicus Uvarov, I922

8. Calliptamuloides Dirsh, 1956

9. Calliptamulus Uvarov, 1922

10. Euryphymus Stål, I873

II. Kevanacris Dirsh, I96I
I2. Pachyphymus Uvarov, I922

I3. Phymeurus Giglio-Tos, 1907

I4. Platacanthoides Kirby, I9Io

I5. Plegmapteroides Dirsh, I959

16. Plegmapteropsis Dirsh, I956

17. Plegmapterus Martinez, 1898

I8. Rachitopis Uvarov, 1922

19. Rhodesiana Dirsh, 1959

20. Somaliacris Dirsh, 1956

21. Surudia Uvarov, I930

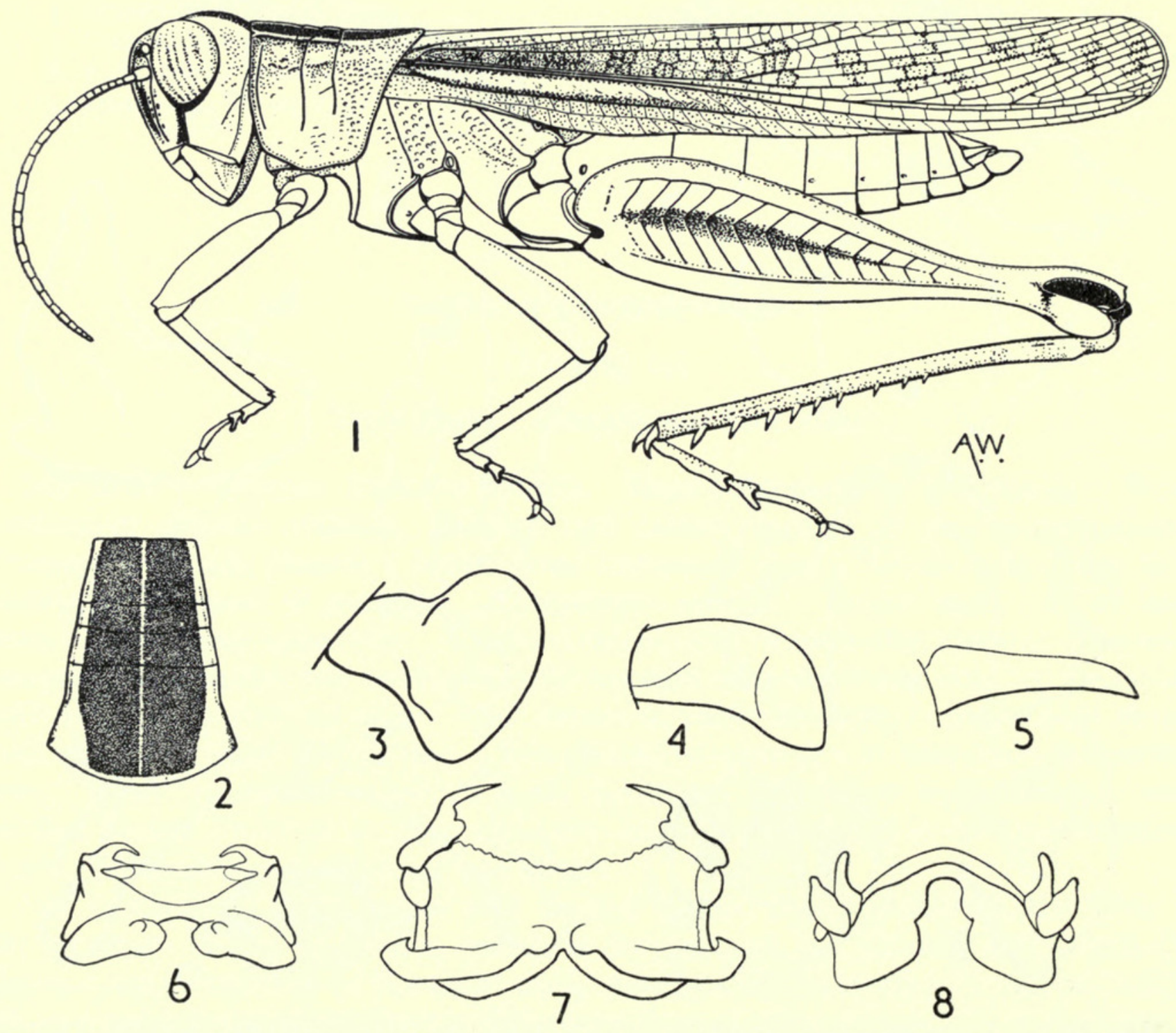

FIG. 28. I-2. Eyprepocnemis plorans (Charp.). I. Male. 2. Dorsum of pronotum, showing characteristic pattern. 3-5. Male cerci. 3. Phyllocercus bicoloripes Uv. 4. Heteracris herbacea (Serv.). 5. Eyprepocnemis plorans (Charp.). 6-8. Epiphalli. 6. Heteracris calliptamoides Uv. 7. Phyllocercus bicoloripes Uv. 8. Eyprepocnemis plorans Charp. 


\section{Subfamily Eyprepocnemidinae}

\section{(Text-fig. 28) \\ Type genus : Eyprepocnemis Fieber, I853}

Size small to large. Head subconical to subglobular. Fastigium of vertex merging roundly with frontal ridge; inter-ocular distance wide. Pronotum with median and lateral carinae (lateral sometimes obliterated) ; dorsum crossed by three sulci. Prosternal process cylindrical or antero-posteriorly compressed. Mesosternal interspace open. Elytra and wings fully developed or reduced. Tympanum present. Lower basal lobe of hind femur shorter than upper one. External apical spine of hind tibia absent. Male cercus at apex flattened, widened or subacute and down curved. Basal and apical valves of penis flexured. Epiphallus bridge-shaped, mostly with poorly sclerotized bridge; ancorae and lophi present. Stridulatory mechanism not found.

The subfamily Eyprepocnemidinae was established by Jakobson (Jakobson \& Bianki, I904), but was disregarded by later authors and considered as part of the subfamily Catantopinae and recently (Mistshenko, I952) as a tribe of it.

The subfamily is defined by the following combination of characters : a weakly sclerotized and rather wide bridge of the epiphallus, with curved and sometimes rather complicated ancorae; slender hind femur (with few exceptions); rounded and rather wide fastigium of the vertex ; presence of lateral carinae on the pronotum (rarely obliterated) ; and apically compressed male cerci. These characters are not confined to the Eyprepocnemidinae, but their combination defines the Eyprepocnemidinae as a natural group.

Eyprepocnemidinae are distributed in Africa, S. Europe, Asia and Australia. List of examined genera :

I. Amphiprosopia Uvarov, I92I

2. Asmara I. Bolivar, I9I4

3. Belonocnemis I. Bolivar, I9I4

4. Brownacris Dirsh, 1958

5. Burmacris Ramme, I94I

6. Cataloipus I. Bolivar, I89o

7. Choroedocus I. Bolivar, I9I4

8. Cyathosternum I. Bolivar, I88I

9. Cyclopternacris Ramme, I928

Io. Macrotona Brunner, I893

II. Euprepocnemides I. Bolivar, I9I4

I2. Eyprepocnemis Fieber, I853

I3. Eupreponotus Uvarov, I92I

I4. Habrocnemis Uvarov, 1930

15. Heteracris Walker, I 870
I6. Horaeocerus Saussure, I 899
I7. Jucundacris Uvarov, I92I
I8. Macrocara Uvarov, I 930
19. Navasia Kirby, I9I 4
20. Oxyaeida $\mathrm{I}$. Bolivar, I9I4
21. Paraeuprepocnemis Brunner, I 893
22. Parathisoicetrus Ramme, I929
23. Phyllocercus Uvarov, I94I
24. Taramassus Giglio-Tos, I907
25. Thisoicetrellus Uvarov, I92 I
26. Thisoicetrinus Uvarov, I92 I
27. Tropidiopsis I. Bolivar, I9I I
28. Tylotropidius Stål I 873

I5. Heteracris Walker, I87o

I6. Horaeocerus Saussure, I899

I7. Jucundacris Uvarov, I92I

I8. Macrocara Uvarov, I930

19. Navasia Kirby, I9I4

20. Oxyaeida I. Bolivar, I9I4

2I. Paraeuprepocnemis Brunner, I893

22. Parathisoicetrus Ramme, I929

23. Phyllocercus Uvarov, I94I

24. Taramassus Giglio-Tos, 1907

25. Thisoicetrellus Uvarov, I92I

26. Thisoicetrinus Uvarov, I92I

28. Tylotropidius Stål I 873

\section{Subfamily Catantopinae}

(Text-fig. 29)

Type genus: Catantops Schaum, I853

Size from small to large. Head of variable shape. Median carina of pronotum present or absent ; lateral carinae only rarely present. Prosternal process present. 

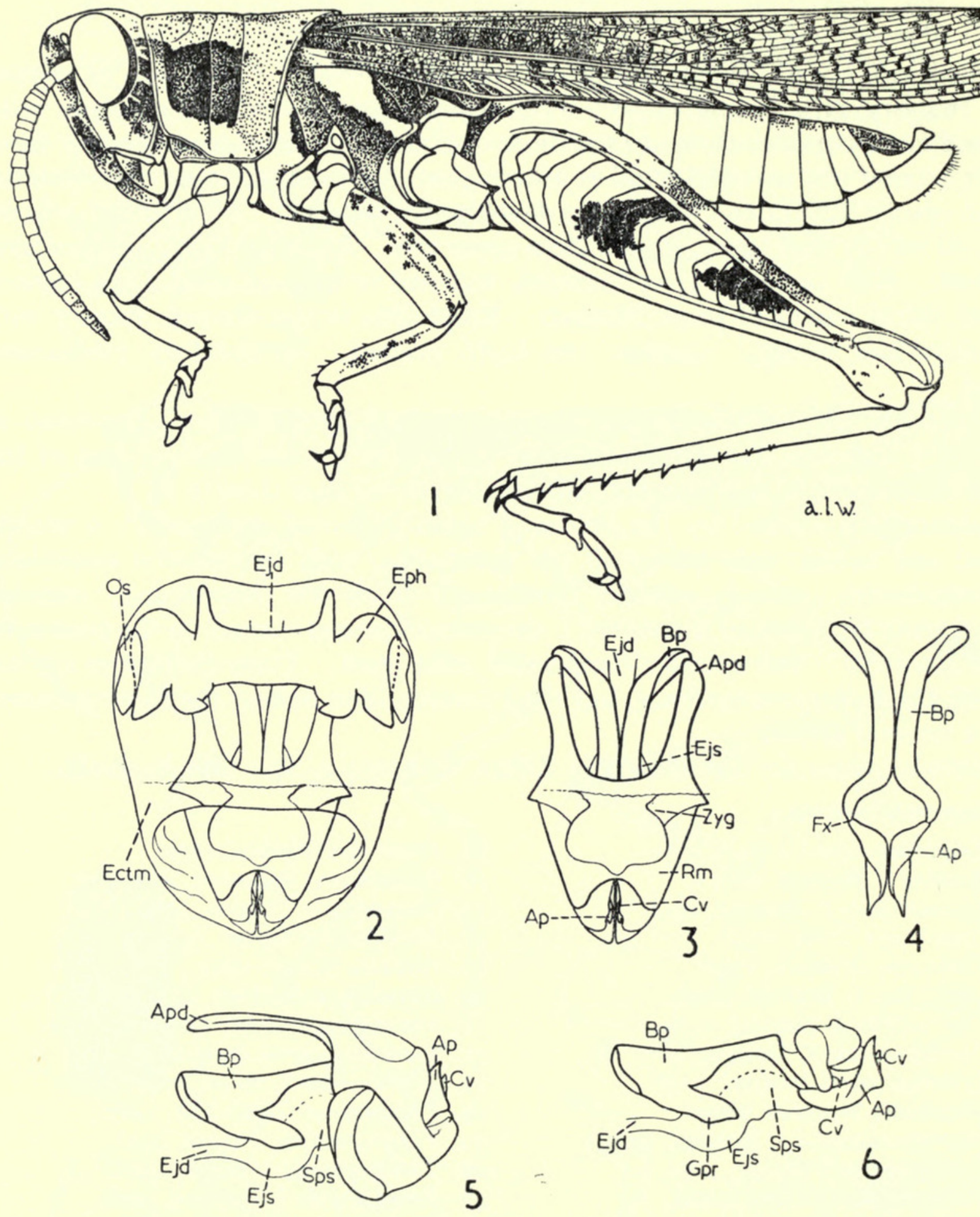

a.l.w.

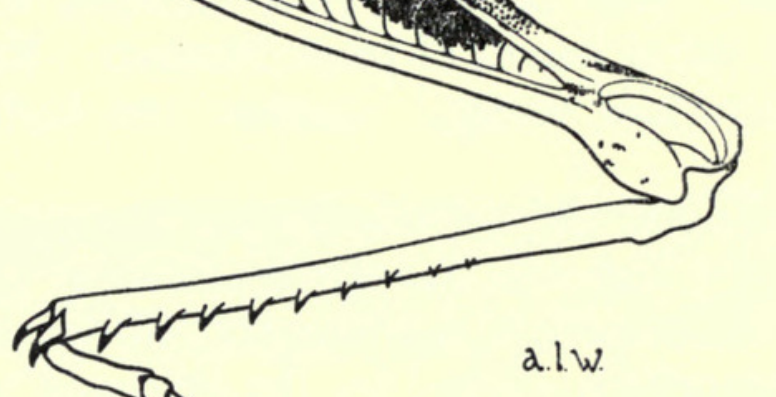


Mesosternal lobes rounded. Elytra and wings fully developed, reduced or absent ; intercalary vein of medial area of elytron absent (rarely present). Tympanum normally present, rarely absent. Lower basal lobe of hind femur normally shorter than upper one. External apical spine of hind tibia present or absent. Basal and apical valves of penis flexured. Epiphallus bridge-shaped, sometimes with divided bridge ; ancorae mostly present ; lophi of variable form, mostly present. Stridulatory mechanism not found.

The Catantopinae are closely related to Cyrtacanthacridinae and Acridinae, but may be separated from Cyrtacanthacridinae by the rounded mesosternal lobes ; and from Acridinae by the presence of a prosternal process, the absence of an intercalary vein in the medial area of the elytron and the non-articulated ancorae of the epiphallus, although these three characters do occur in certain Acridinae.

The subfamily urgently needs further study. It would be premature to attempt to subdivide it now, since there must be a large number of undescribed genera, particularly in the tropics.

The large subfamily Catantopinae, even in its present reduced scope, still represents a highly heterogeneous assemblage. It was usual to put into the subfamily any genus which would not fit elsewhere. As a result, the subfamily not only contains the basic group Catantopini but has also been a dumping ground for everything which needs further investigation.

The subfamily Catantopinae is distributed in the whole world, and includes a large number of genera. No list is given for obvious reasons.

\section{Subfamily Cyrtacanthacridinae}

(Text-fig. 30)

Type genus : Cyrtacanthacris Walker, I870

Size large or medium. Antenna filiform. Head subglobular; frons vertical. Pronotum without lateral carinae; dorsum crossed by three sulci. Prosternal process large. Mesosternal interspace open; mesosternal lobes rectangular. Elytra and wings fully developed or reduced. Tympanum present. Lower basal lobe of hind femur shorter than upper one. External apical spine of hind tibia absent. Basal and apical valves of penis flexured. Epiphallus robust, bridge-shaped, with small or without any ancorae; lophi large lobiform or tooth-like. Stridulatory mechanism not found.

The main characteristic features of Cyrtacanthacridinae are the rectangular mesosternal lobes, the large size of the body, the strong epiphallus, with the ancorae shortened or absent, and the absence of lateral carinae on the pronotum.

It might be possible to regard Cyrtacanthacridinae as a group or a tribe within the subfamily Catantopinae, but their characters are sufficiently definite for them to be regarded as a separate subfamily. 
The subfamily is distributed over the tropical, subtropical and temperate zones of the whole world.

List of known genera:
I. Acanthacris Uvarov, 1924
2. Acridoderes I. Bolivar, 1889
3. Adramita Uvarov, 1936
4. Anacridium Uvarov, 1923
5. Austracris Uvarov, 1924
6. Bryophyma Uvarov, 1923
7. Chondracris Uvarov, 1924
8. Congoa I. Bolivar, I9II
9. Cyrtacanthacris Walker, 1870
Io. Finotina Uvarov, 1924
II. Gowdeya Uvarov, I923
12. Kinkalidia Sjöstedt, r93I
13. Kraussaria Uvarov, 1924
I4. Melicodes Uvarov, 1923

I5. Nomadacris Uvarov, 1924

I6. Ootua Uvarov, 1927

I7. Ornithacris Uvarov, 1924

18. Orthacanthacris Karsh, I896

19. Pachyacris Uvarov, 1923

20. Pachynotacris Uvarov, 1923

21. Patanga Uvarov, 1923

22. Phyxacra Karny, 1907

23. Rhadinacris Uvarov, 1923

24. Rhytidacris Uvarov, 1923

25. Schistocerca Stål, 1873

26. Valanga Uvarov, 1923

27. Willemsea Uvarov, 1923

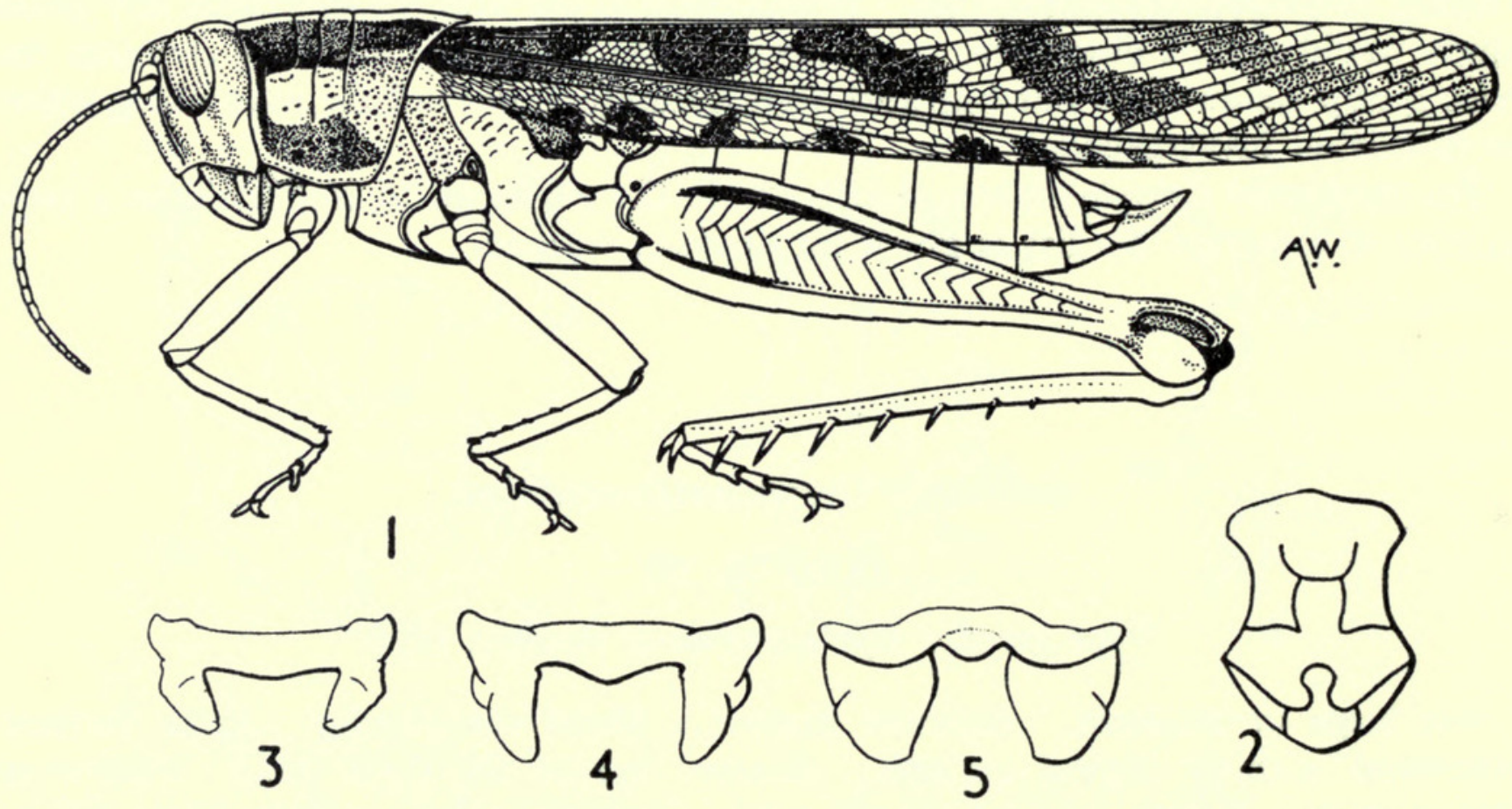

FIG. 30. I. Cyrtacanthacris tatarica (L.), male. 2. Meso- and metasternum of Schistocerca gregaria Forsk. 3-5. Epiphalli. 3. Cyrtacanthacris tatarica (L.). 4. Ornithacris cyanea (Stoll). 5. Anacridium aegyptium (L.).

\section{Subfamily Egnatiinae}

\section{(Text-fig. 3I)}

Type genus : Egnatius Stål, I876

Small. Head subconical. Median and lateral carinae of pronotum present. Prosternum with low convexity. Mesosternal interspace very short, mesosternal furcal suture being strongly curved backwards. Elytra and wings fully developed or 
REVISION OF THE FAMILIES AND SUBFAMILIES OF ACRIDOIDEA 4II reduced; weak intercalary vein of medial area of elytron present or absent. Tympanum present. Abdominal tergites of male, on sides, often with transverse stridulatory ridges. Arolium very small. Basal and apical valves of penis flexured. Epiphallus bridge-shaped; ancorae articulated with bridge ; lophi present.

The affinities of the subfamily Egnatiinae are rather obscure. Not long ago the genera concerned were regarded as members of the Oedipodinae. Bey-Bienko (I95I) recognized them as a separate subfamily on the basis of the peculiar shape of the mesosternal furcal suture, the peculiar stridulatory mechanism in some of the genera

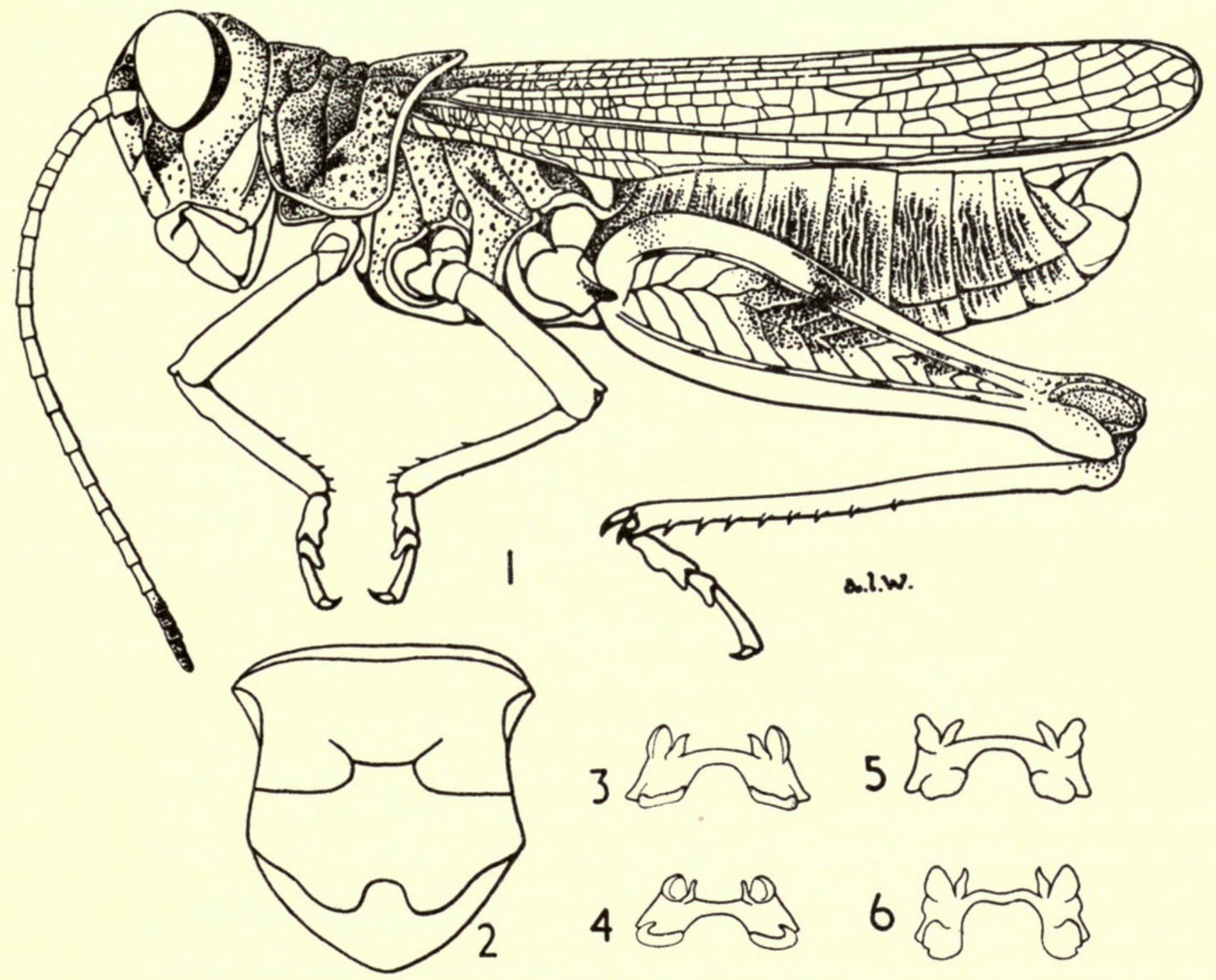

FIG. 3I. I-2. Egnatius apicalis St. I. Male. 2. Meso- and metasternum. 3-6. Epiphalli.

3. Charora crassivenosa Sauss. 4. Egnatius apicalis St. 5. Egnatiella cabrerai I. Bol.

6. Leptoscirtus isphahanicus Uv.

and the poor development or absence of a vena intercalata in the medial area of the elytron. Slifer (I939) noticed that they possess Comstock-Kellogg glands, which are otherwise believed to occur only in Catantopinae. Bryantseva (I953) studied the foregut in Egnatiinae, and found that the folds and sculpture of its internal surface are similar to those in Catantopinae and different from those of Oedipodinae. On this basis it can be suggested that they are nearer to the Catantopinae than to any other subfamily. 
The Egnatiinae are distributed in N. Africa and SW. Asia.

\section{List of known genera :}

I. Charora Saussure, 1888

2. Egnatius Stål, 1876

3. Egnatioides Vosseler, 1902
4. Egnatiella I. Bolivar, I9I4

5. Leptoscirtus Saussure, I 888

6. Paregnatius Uvarov, 1933
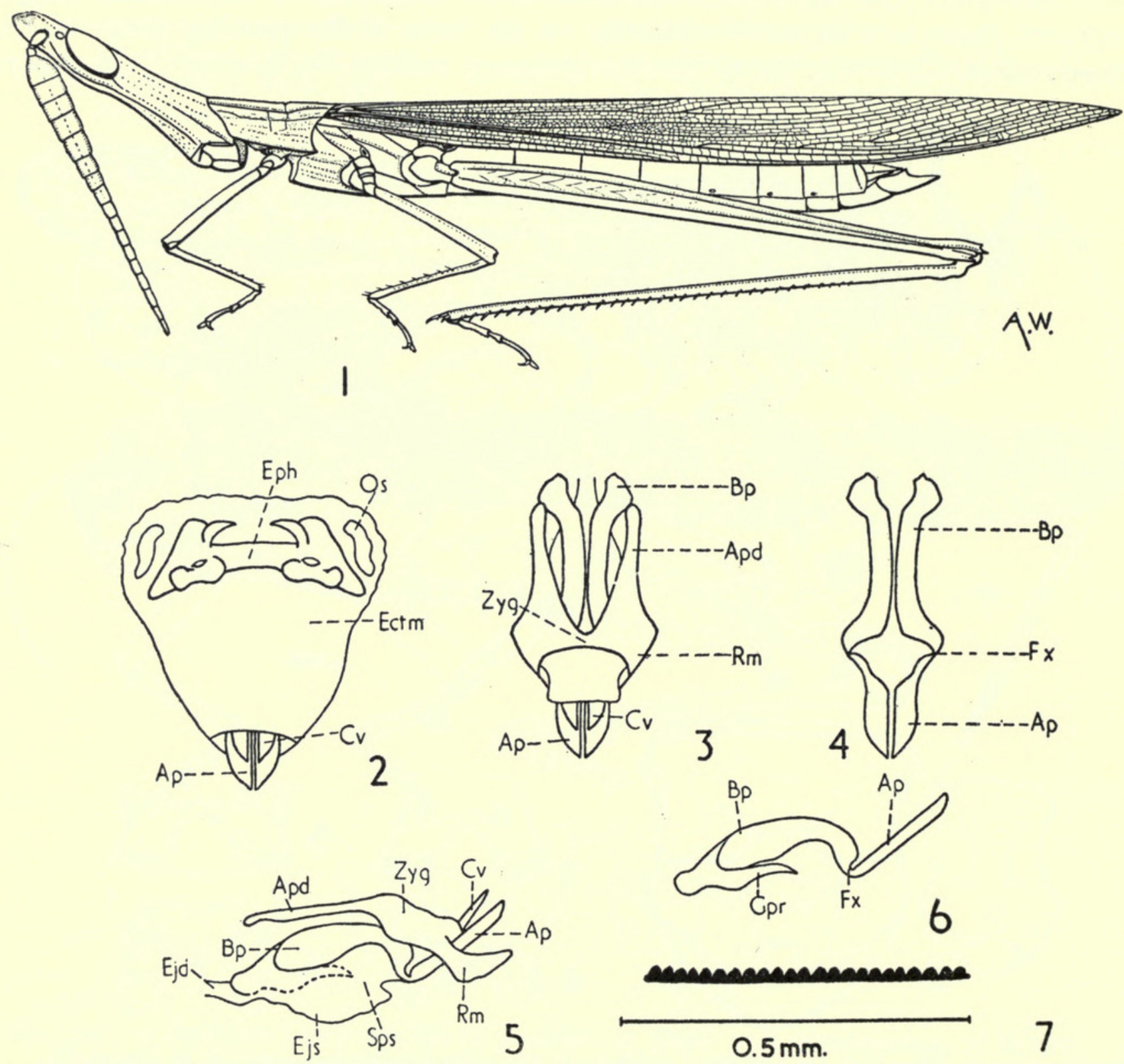

Fig. 32. Acrida turrita L. I. Male. 2-6 Phallic complex. 2. Whole phallic complex from above. 3. The same, but ectophallic membrane and epiphallus removed. 4. Penis from above. 5. As fig. 3, but in profile. 6. Penis, in profile. 7. Serrated intercalary vein of Oedipoda miniata (Pall.).

\section{Subfamily Acridinae}

(Text-fig. 32)

Type genus : Acrida Linnaeus, I758

Size small to large. Head of variable shape. Median and lateral carinae of pronotum mostly present. Prosternal process mostly absent. Elytra and wings fully 
developed, reduced or absent ; intercalary vein of medial area of elytron sometimes strong and serrated, sometimes weak, disappearing, but mostly present. Stridulatory mechanism, consisting of variable serration of elytra or wings, often present. Tympanum normally present. Lower basal lobe of hind femur shorter than upper one. Basal and apical valves of penis flexured. Epiphallus bridge-shaped; ancorae mostly present, articulated with bridge ; lophi mostly present.

The subfamily Acridinae is related on the one hand to Catantopinae, on the other to Truxalinae.

The presence in some genera of a prosternal process connects them with Catantopinae, from which they differ, however, in the combination of other characters (see Catantopinae). From Truxalinae they differ clearly in the absence of stridulatory serration on the internal side of the hind femur. In the case of wingless genera and species, however, it is extremely difficult to decide to what subfamily they belong, since the phallic complex of Acridinae and Truxalinae does not provide clear separating features. The subfamily may be divided into several groups or tribes and one of them could be Oedipodini, which has been in the past regarded as a subfamily, mainly on the grounds of general appearance. Dirsh (I956) reduced it to a group. The only diagnostic character of Oedipodini suggested by Uvarov (I942), the serrated intercalary vein of the medial area of the elytra, is not reliable since there is a full transition to the Acridinae, the intercalary vein of which may be serrated, irregular, or altogether absent.

The Acridinae are distributed throughout the world and include a vast number of genera, a list of which would be superfluous.

\section{Subfamily Eremogryllinae}

\section{(Text-fig. 33)}

\section{Type genus: Eremogryllus Krauss, I902}

Small. Head subconical or subglobular. Pronotum with median and lateral carinae. Prosternum with low, transverse convexity and slightly raised anterior margin. Mesosternal interspace short and wide. Elytra and wings fully developed; elytron with sharp radial vein (stridulatory specialization); intercalary vein of medial area absent. Tympanum present. Stridulatory serration, consisting of articulated pegs on internal side of hind femur present; lower basal lobe of hind femur shorter than upper one. Male cercus short, thickened, with incurved, acute apex. Subgenital plate shortened, transverse. Phallic complex relatively very small. Basal and apical valves of penis flexured. Epiphallus with divided bridge ; ancorae small, incurved ; lophi tooth-like, with strongly acute apices.

The subfamily Eremogryllinae was established recently (Dirsh, I956) mainly on the basis of the peculiar structure of the epiphallus and the external genital appendages of the male. It shares the type of stridulatory mechanism with Truxalinae but the structure of the phallic complex is very different. There is no close relationship between Evemogryllinae and the other subfamilies of Acrididae.

The Eremogryllinae occur only in N. Africa.

\section{List of known genera :}

I. Evemogryllus Krauss, I902

2. Notopleura Krauss, I902

ENTOM, Iо, 9. 

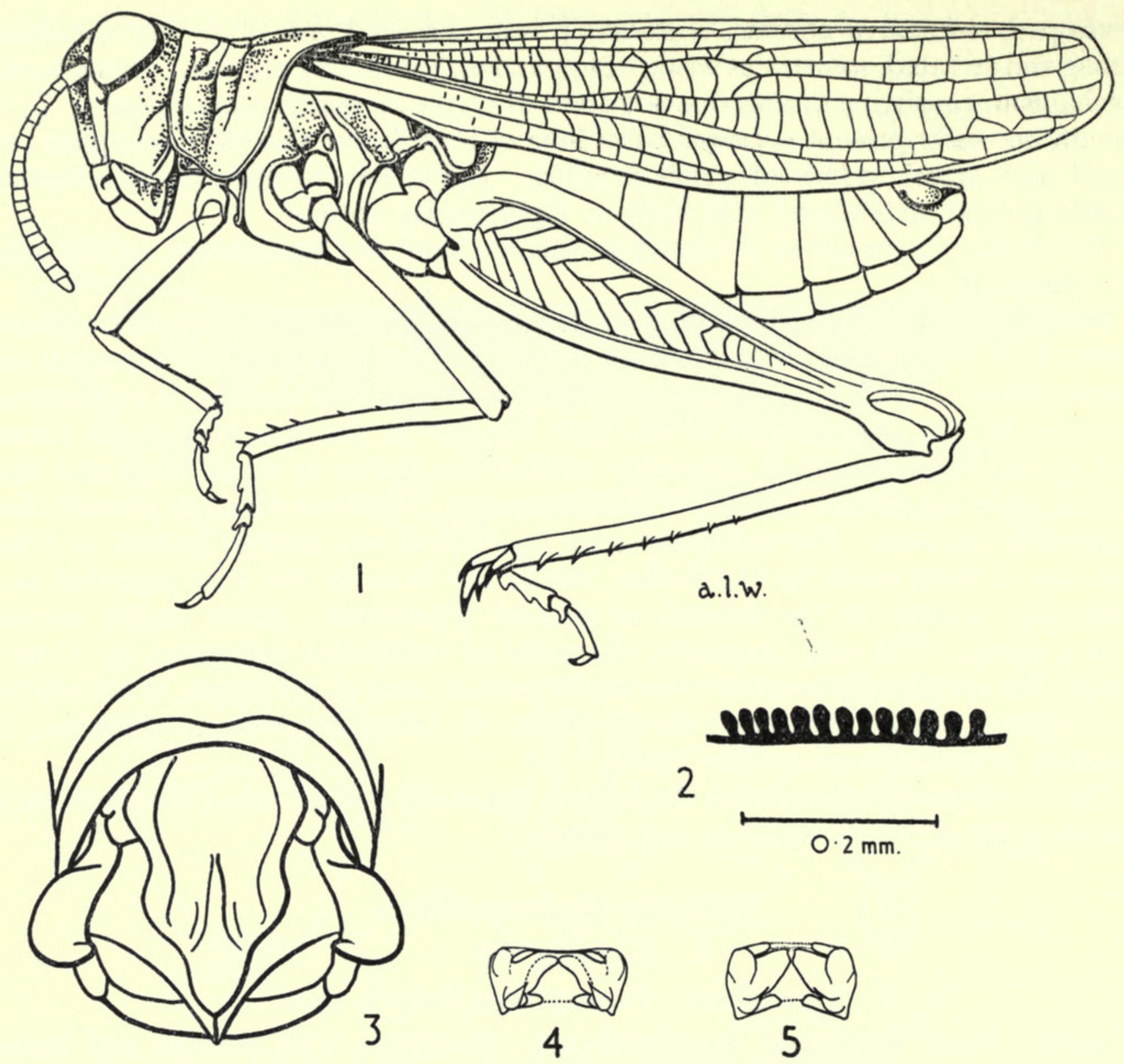

Fig. 33. I-4. Evemogryllus hammadae Kr. I. Male. 2. Stridulatory serration on internal side of hind femur. 3. End of male abdomen from above. 4. Epiphallus. 5. Epiphallus of Notopleura saharica $\mathrm{Kr}$.

\section{Subfamily Truxalinae}

(Text-fig. 34)

\section{Type genus: Truxalis Fabricius, I775}

Size from small to large. Head of variable shape. Median and lateral carinae of pronotum mostly present. Prosternal process absent, rarely present. Elytra and wings fully developed or reduced; radial or radial and medial vein of elytron sharp (stridulatory specialization) ; intercalary vein of medial area absent. Tympanum present. Lower basal lobe of hind femur shorter than upper one; stridulatory serration with articulated or not articulated pegs on internal side of hind femur present. Basal and apical valves of penis flexured. Epiphallus bridge-shaped; ancorae articulated with bridge; lophi present. 


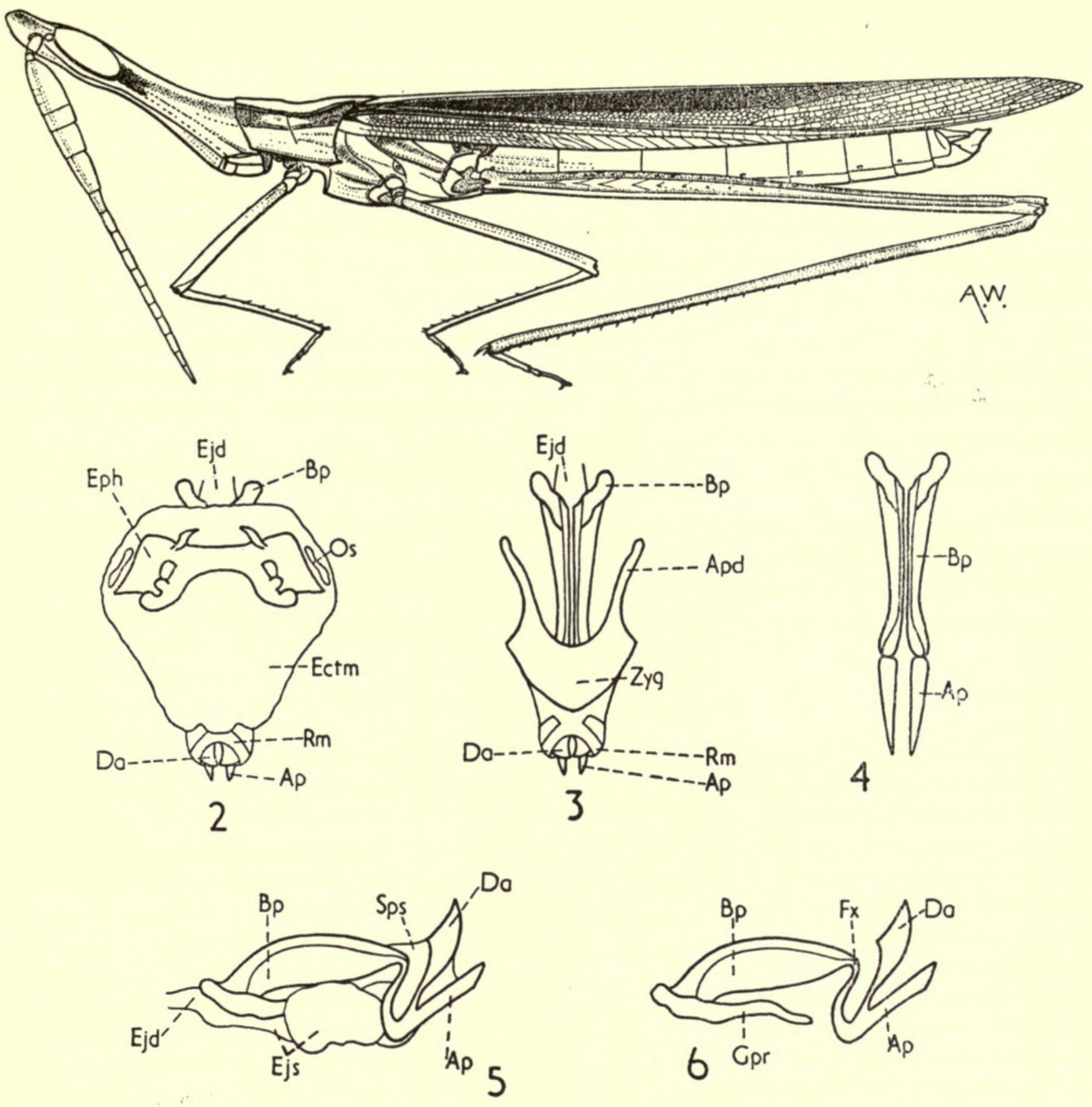

\section{0 \\ $0.5 \mathrm{~mm}$.}

8

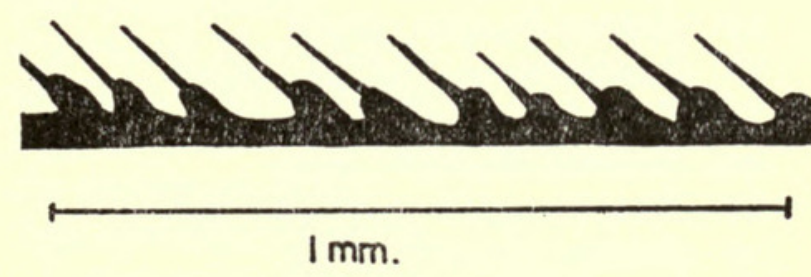

7

Fig. 34. Truxalis grandis Klug. I. Male. 2-6. Phallic complex. 2. Whole phallic complex from above. 3. The same, but ectophallic membrane and epiphallus removed. 4. Penis from above. 5. As fig. 3, but in profile. 6. Penis in profile. 7. Stridulatory serration on internal side of hind femur (not articulated). 8. Gomphocerus sibiricus (L.), stridulatory serration (articulated). 
The name Truxalinae has been used by many authors for the complex which is now divided into Acridinae and Truxalinae. Externally, representatives of both subfamilies present a series of parallel forms, but Truxalinae possess a stridulatory mechanism of a definite structure, found elsewhere only in Eremogryllinae. A somewhat similar structure is found in two South American genera of Catantopinae (see p. 358).

It might be argued that a single character is insufficient for separating the Truxalinae from the Acridinae, but it consists of a complicated structure of articulated or non-articulated stridulatory pegs, combined with the second part of the mechanism comprising sharp veins for friction and often widened areas of the elytron which serve as resonators. This highly specialized stridulatory mechanism constitutes a character so well defined that no confusion between winged members of the two subfamilies can possibly arise. There are no intermediate forms between Truxalinae and other subfamilies.

The Truxalinae are distributed throughout the world except Australia and Madagascar.

List of examined genera:

I. Acantherus Scudder, I902

2. Achurum Saussure, I86I

3. Acocksacris Dirsh, 1958

4. Acridarachnea I. Bolivar, Igo8

5. Acrolophitus Thomas, I87I

6. Afrohippus Uvarov, I94I

7. Ageneotettix McNeil, I897.

8. Amblytropidia Stål, I873

9. Amesotropis Karsch, 1893

ro. Amphitornus McNeil, 1897

II. Anablepia Uvarov, 1938

I2. Anaptygus Mistshenko, I95I

I3. Arcyptera Serville, I839

I4. Aswatthamanus Kirby, I9I4

I5. Aulacobothrus I. Bolivar, I902

I6. Aulocara Scudder, I876

I7. Azarea Uvarov, I926

I8. Baidoceracris Chopard, I947

I9. Bodenheimerella Uvarov, I933

20. Bootettix Bruner, I89o.

21. Brachycrotaphus Krauss, 1877

22. Brainia Uvarov, 1922

23. Capulica I. Bolivar, I9I 8

24. Clinocephalus Morse, I896.

25. Chloealtis Harr, I $84 \mathrm{I}$

26. Chorthippus Fieber, 1852

27. Chromotruxalis Dirsh, I95I

28. Chrysochraon Fischer, 1853.

29. Cophohippus Uvarov, 1953

3o. Cordillacris Rehn, I9oI

3I. Dhimbama Henry, I940

32. Diablepia Kirby, 1902

33. Dichromorpha Morse, 1896

34. Dnopherula Karsch, 1896

35. Dociostaurus Fieber, I853

36. Eleutherotheca Karny, I907.

37. Eremiacris Hebard, I929

38. Evemippus Uvarov, 1926

39. Evitettix Bruner, I 890

40. Ermia Popov, I957

41. Euchorthippus Tarbinsky, I925

42. Euplectrotettix Bruner, I9O2

43. Eupnigodes McNeil, I897

44. Euthystiva Fieber, I853

45. Faureia Uvarov, I92I

46. Gomphocerippus Roberts, I94I

47. Gomphocerus Thunberg, I8I5

48. Goniatron Bruner, I905

49. Goniocara Uvarov, I953

5o. Heliaula Caudell, I9I 5

51. Kirmania Uvarov, I933

52. Komandia Uvarov, 1953

53. Krausella I. Bolivar, I909

54. Leuconotus Bruner, 1904

55. Leva I. Bolivar, 1909

56. Ligurotettix McNeil, I897

57. Lounsburyna Uvarov, 1922

58. Macneillia Scudder, 1898

59. Madurea I. Bolivar, 1902

6o. Mermiria Stål, 1873

61. Mesochloa Scudder, 1898

62. Mesopsis I. Bolivar, I906

63. Milleviola Uvarov, 1953

64. Mizonocara Uvarov, I9I2 
65. Mongolotettix Rehn, I928

66. Morseiella Hebard, I925

67. Myrmeleotettix I. Bolivar, I9I4

68. Napaia McNeil, I897

69. Notostaurus Bey-Bienko, I933

70. Ochrilidia Stål, I873

7I. Omocestus I. Bolivar, I878

72. Opeia McNeil, I 897

73. Oxytruxalis Dirsh, 1950

74. Paragonista Willemse, 1932

75. Paragymnobothrus Karny, I9ro

76. Pararcyptera Tarbinsky, I930

77. Paropomala Scudder, 1899

78. Pedioscirtetes Thomas, 1873

79. Peruvia Scudder, I89o

8o. Phlibostroma Scudder, I875

81. Phonogaster Henry, I940

82. Phorenula I. Bolivar, I909

83. Platypternodes I. Bolivar, I908

84. Pnorisa Stål, I86I

85. Podismopsis Zubowsky, I899.

86. Primnia Stål, I 873

87. Pesctrocnemus Henry, I940

88. Psendegnatius Dirsh, 1956

89. Pseudoarcyptera I. Bolivar, I909

\author{
90. Pseudogmothela Karny, I910 \\ 91. Pseudopomala Morse, I896 \\ 92. Psoloessa Scudder, 1875 \\ 93. Ptygonotus Tarbinsky, I927 \\ 94. Quangula Uvarov, I953 \\ 95. Ramburiella I. Bolivar, I 906 \\ 96. Raphotitta Karsch, 1896 \\ 97. Scyllina Stål, I873 \\ 98. Silvitettix Bruner, I904 \\ 99. Sinipta Stål, I860 \\ Ioo. Sporobolius Uvarov, I94I \\ IoI. Stauroderus I. Bolivar, I897 \\ I02. Staurorhectus Giglio-Tos, I897. \\ I03. Stenobothrus Fischer, 1853 \\ I04. Stenohippus Uvarov, I926 \\ I05. Stivapleura Scudder, 1876 \\ Io6. Syrbula Stål, I873. \\ 107. Thyridota Uvarov, 1925 \\ I08. Tinaria Stål, I86I \\ I09. Truxalis Fabricius, I 775 \\ I 10. Truxaloides Dirsh, I950 \\ III. Xenotruxalis Dirsh, I950 \\ I12. Xerohippus Uvarov, $194^{2}$ \\ II3. Yendia Ramme, 1929 \\ II4. Zapata Brunner, I902
}

\section{EXPLANATION OF SYMBOLS USED IN THE FIGURES OF THE PHALLIC COMPLEX}

$A p$, apical valves of penis.

$A p d$, apodemes.

Art, articulation.

$B f$, basal fold.

$B p$, basal valves of penis.

Cng, cingulum.

$C v$, valves of cingulum.

$D a$, dorsal appendices of penis.

Ect, ectophallus.

Ectm, ectophallic membrane.

Ectv, ectophallic valves.

$E j$, ejaculatory duct.

Ejs, ejaculatory sac.

End, endophallus.

Eph, epiphallus.
$F x$, flexure.

$G p r$, gonopore processes.

Gprs, gonopore sclerite.

$m$, membrane.

$O P$, opening.

$O s$, oval sclerites.

$P$, penis.

Pht, phallotreme.

$P o$, pouch of phallus.

$R m$, ramus of cingulum.

$S c l$, sclerites of indefinite meaning.

$S h$, sheath of penis,

$S p s$, spermatophore sac.

$V a$, ventral appendices of penis.

$Z y g$, zygoma.

\section{REFERENCES}

ANDER, K. I939. Vergleichend-anatomische und phylogenetische Studien uber die Ensifera (Saltatoria). Opusc. ent. Suppl. II, Lund.

BEIER, M. I955. Orthopteroidea. In Bronn's Klassen und Ordnungen. Leipzig.

Bey-Bienko, G. J. \& Mistshenko, L. L. I95I. Acridids of the fauna of U.S.S.R. Leningrad.

Vol. I, 2 . 
Bolivar, I. I884. Monografia de los Pirgomorfinos. An. Soc. esp. Hist. nat. 13.

- I904. Notas sobre los Pirgomorfidos. Bol. Soc. esp. Hist. nat. 4.

- I909. Pyrgomorphinae. Genera Insect. 90.

- i9r6. Pamphaginae. Ibid. 170.

BRunNer von Wattenwyl, C. I893. Revision du système des Orthoptères et description des espèces rapportèes par M. Leonardo Fea de Birmanie. Ann. Mus. Stor. nat. Genova (2), 13.

Bryantseva, I. B. I953. Peculiarities in the structure of the foregut of Acridids of the subfamily Egnatiinae (Orthoptera, Acrididae). Rev, Ent. U.R.S.S. 33. Leningrad.

BurtT, E. I946. Observations on East African Pamphagidae (Orthoptera, Acrididae) with particular reference to stridulation. Proc. R. ent. Soc. Lond. (A) 2I, pt. 7.9.

Carpentier, F. I933. Sur quelques particularités du thorax et des pattes de Cylindroryctes spegazzinii Giglio-Tos. V. Int. Congr. Ent.

- 1936. Le thorax et ses appendices chez les vrais et chez les faux Gryllotalpidae. Mém. Mus. Roy. de l'Hist. Nat., 2 ser., 4.

CHOPARD, L. I920. Recherches sur la Conformation et le développement des derniers segments abdominaux chez les Orthoptères. Paris.

— 1938. La Biologie des Orthoptères. Enc. Entom. Paris.

— I949. Orthoptera. In Traité de Zoologie. Ed. P. Grassé. Vol. IX. Paris.

Dirsh, V. M. I952. The restoration of the subfamily Trigonopteryginae Walker (Orthoptera, Acrididae). Ann. Mag. nat. Hist. (12), 5.

- 1954. Lathicerinae, a new subfamily of Acrididae (Orthoptera). Ibid. (I2), 7.

- I955. Tanaoceridae and Xyronotidae: two new families of Acridoidea (Orthoptera). Ibid. (1 2), 8.

I956. The phallic complex in Acridoidea (Orthoptera) in relation to taxonomy. Trans. R. ent. Soc. Lond. $108: 7$.

- 1957. The spermatheca as a taxonomic character in Acridoidea (Orthoptera). Proc. R. ent. Soc. Lond. (A) $32: 7-9$.

- 1958. Revision of the group Portheti (Orthoptera, Acridoidea). Eos, Madr. 34.

Ewer, D. W. 1958. Notes of acridid anatomy. V. The pterothoracic musculature of Lentula callani Dirsh. J. Ent. Soc. S. Afr. 21, i.

Handlirsch, A. I908. Die fossilen Insecten und die Phylogenie der rezenten Formen. Leipzig. Helwig, E. R. I958. Cytology and Taxonomy. Bios, 29, ii. 2.

Henry, G. M. I942. Three remarkable stridulatory mechanisms in Acrididae. Proc. R. ent. Soc. Lond. (A), 17.

Jacobson, G. \& Bianki, V. L. I904. Orthoptera and Pseudoneuroptera of the Russian Empire. St. Petersburg.

Karsch, F. I896. Neue Orthopteren aus dem tropischen Africa. Stettin. ent. Ztg. 57.

Kevan, D. KeIth McE. I952. On the systematic position of two anomalous genera previously placed in the subfamily Pyrgomorphinae (Orth., Acrididae). Ent. mon. Mag. 88.

- I953. An unusual stridulatory mechanism in Xyronotus aztecus Sauss. (Orth., Acrididae). Ibid. 89.

- I954. Méthodes inhabituelles de production de son chez les Orthoptères. Ann. Épiphyt., Coll. l'Acoust. d. Orth.

Latreille, P. A. I793. Précis des caractères Génériques des Insectes. Bordeaux.

- I8I7. Les Crustaces, les Arachnides et les Insectes. Cuvier (G.L.C.F.D.). Le Règne Animal. Paris.

Liebermann, J. I942. Lista definitiva de los Acridoideos de Chile. Bol. Sanid. veg., Santiago, 2, No. 2.

- 1943. Generos y especies de nuevos Acridoideos Chilenos. Rev. soc. Ent. argent. ii, No. 5 .

Mello-Leitão, C. DE. I939. Estudio monográfico de los Proscopidos. Rev. Mus. La Plata, I.

Mistshenko, L. L. I952. Catantopinae. Fauna U.S.S.R. Leningrad. 
RAGGe, D. R. I955. The Wing-venation of the Orthoptera Saltatoria. Bull. Brit. Mus. (nat. Hist.). London.

RehN, J. A. G. I938. On the relationship of the Nearctic genus Dracotettix (Orthoptera, Acrididae). Proc. Acad. nat. Sci. Philad. 90.

I948. The Acridoid Family Eumastacidae (Orthoptera). A review of our knowledge of its components, features and systematics, with a suggested new classification of its major groups. Ibid. $\mathbf{1 0 0}$.

- I948. The locust genus Tanaocerus as found in the United States, and the description of a related new genus (Orthoptera, Acridoidea). Ibid. 100.

Rehn, J. A. G. \& Grant, H. J. I958. The phallic complex in the subfamilies of New World Eumastacidae and the family Tanaoceridae. Ibid. 110.

- I959. On certain Old World genera of Teratodini recently placed in the subfamily Romaleinae. Not. Nat. Acad. Philad. No. 317.

- 1959. The correct placement of the genus Prionacris (Orthoptera; Acrididae; Cyrtacanthacridinae). Ibid. No. 323.

— - I959. An analysis of the tribes of the Romaleinae with special reference to their internal genitalia (Orthoptera; Acrididae). Trans. Amer. ent. Soc. 85.

_ I959. A review of the Romaleinae (Orthoptera ; Acrididae) found in America north of Mexico. Proc. Acad. nat. Sci. Philad. 111.

Roberts, H. R. I94I. A comparative study of the subfamilies of Acrididae (Orthoptera) primarily on the basis of their phallic structures. Ibid. 93,

Saussure, H. I888. Additamenta ad Prodromum Oedipodiorum. Mém. Soc. Phys. Genève, 30 (I).

I899. Orthoptera. In: Wissenschaftliche Ergebnisse der Reisen in Madagascar und Ostafrica in den Jahren I889-95 von Dr. A. Voeltzkow. Abh. senckenb. naturf. Ges. 21.

SchröDER, $\mathrm{CH}$. 1925. Handbuch der Entomologie. Jena.

Shvanwitsh, B. N. I949. General Entomology (in Russian). Leningrad.

Slifer, E. H. I939-43. The internal genitalia of female Acridinae. J. Morph.65: $3 ; 66:$ I ; $67: 2 ; 72: 2$.

1944. Ileal caeca in the Eumastacidae (Orthoptera). Ann. ent. Soc. Amer. $37: 4$.

SNodgrass, R. E. I935. The abdominal mechanism of a grasshopper. Smithson. misc. Coll. $94: 6$. Washington.

Stal, C. I875. Observations orthopterologiques. K. svenska VetenskAkad. Handl. 3 (I4).

I 876 . Observations orthopterologiques. (2). Ibid. 4 (5).

Uvarov, B. P. I925. On some new short-horned grasshoppers (Acrididae) from South Africa. Ann. Nat. Mus. 5 (2).

1928. Locusts and Grasshoppers. London.

1928. Orthoptera (in Key for Insects, ed. I. N. Philipiev). Moscow.

1942. New and less known Palaearctic Orthoptera. Trans. Amer. ent. Soc. 67.

1943. The Tribe Thrinchini of the subfamily Pamphaginae and the interrelations of the Acridid subfamilies. Trans. R. ent. Soc. Lond 93 : I.

- 1948. Recent advances in Acridology. Anti-Locust Bull. 1. London.

Uvarov, B. P. \& Popov, G. B. I957. The saltatorial Orthoptera of Socotra. Journ. Linn. Soc. Lond., (Zool.) 43.

Walker, F. I870. Catalogue of the Specimens of Dermaptera Saltatoria in the Collection of the British Museum. London.

Walker, E. M. I9I9, I922. The terminal structures of Orthopteroid insects. Ann. ent. Soc. Amer. 12 (4), 15 (I).

Weber, H. I938. Lehrbuch der Entomologie. Jena.

Westwood, J. O. I94I. Arcana Entomologica. London. 


\section{$2 \mathrm{BHL}$ Biodiversity Heritage Library}

Dirsh, V M. 1961. "A preliminary revision of the families and subfamilies of Acridoidea (Orthoptera, Insecta)." Bulletin of the British Museum (Natural History) Entomology 10, 351-419. https://doi.org/10.5962/bhl.part.16264.

View This Item Online: https://www.biodiversitylibrary.org/item/19383

DOI: https://doi.org/10.5962/bhl.part.16264

Permalink: https://www.biodiversitylibrary.org/partpdf/16264

\section{Holding Institution}

Natural History Museum Library, London

\section{Sponsored by}

Natural History Museum Library, London

\section{Copyright \& Reuse}

Copyright Status: In copyright. Digitized with the permission of the rights holder.

Rights Holder: The Trustees of the Natural History Museum, London

License: http://creativecommons.org/licenses/by-nc-sa/4.0/

Rights: http://biodiversitylibrary.org/permissions

This document was created from content at the Biodiversity Heritage Library, the world's largest open access digital library for biodiversity literature and archives. Visit BHL at https://www.biodiversitylibrary.org. 